UNIVERSIDADE DE SÃO PAULO

FACULDADE DE ECONOMIA, ADMINISTRAÇÃO E CONTABILIDADE

DE RIBEIRÃO PRETO

DEPARTAMENTO DE ADMINISTRAÇÃO

DANILO BENEDINI DE MELLO FERNANDES

O Brasil no contexto da internacionalização de $\mathrm{P} \& \mathrm{D}$ e na disputa pelo investimento estrangeiro das empresas transnacionais.

Orientadora: $\operatorname{Prof}^{\mathrm{a}} \operatorname{Dr}^{\mathrm{a}}$ Simone Vasconcelos Ribeiro Galina 


\author{
Prof $^{\circ}$. Dr ${ }^{\circ}$. Suely Vilela \\ Reitora da Universidade de São Paulo
}

Prof. Dr. Rudinei Toneto Júnior

Diretor da Faculdade de Economia, Administração e Contabilidade de Ribeirão Preto

Prof. Dr. Márcio Mattos Borges de Oliveira

Chefe do Departamento de Administração 
DANILO BENEDINI DE MELLO FERNANDES

\section{O Brasil no contexto da internacionalização de P\&D e na disputa pelo investimento estrangeiro das empresas transnacionais.}

Projeto de pesquisa a ser apresentado à Faculdade de Economia, Administração e Contabilidade de Ribeirão Preto, para a qualificação no Curso de Mestrado no programa de Pós-Graduação em Administração das Organizações.

Orientadora: Prof ${ }^{\mathrm{a}}$. Dr ${ }^{\mathrm{a}}$. Simone Vasconcelos Ribeiro Galina

RIBEIRÃO PRETO

2008 
AUTORIZO A REPRODUÇÃO TOTAL OU PARCIAL DESTE TRABALHO, POR QUALQUER MEIOCONVENCIONAL OU ELETRÔNICO, PARA FINS DE ESTUDO PESQUISA, DESDE QUE CITADA A FONTE.

FICHA CATALOGRÁFICA

Fernandes, Danilo Benedini de Mello Fernandes

O Brasil no contexto da internacionalização de P\&D e na disputa pelo investimento estrangeiro das empresas transnacionais. Ribeirão Preto, 2008.

116 p. : il. ; $30 \mathrm{~cm}$

Dissertação de Mestrado, apresentada à Faculdade de Economia, Administração e Contabilidade de Ribeirão Preto/USP. Departamento de Administração.

Orientador: Galina, Simone Vasconcelos Ribeiro.

1. Indicadores de C\&T. 2. Internacionalização de P\&D. 3. Investimento direto estrangeiro. 4. Patentes. 5. Dados Bibliométricos. 


\section{FOLHA DE APROVAÇÃO}

Danilo Benedini de Mello Fernandes

O Brasil no contexto da internacionalização de $\mathrm{P} \& \mathrm{D}$ e na disputa pelo investimento estrangeiro das empresas transnacionais

Dissertação a ser apresentada à Faculdade de Economia, Administração e Contabilidade de Ribeirão Preto, para a obtenção do título de mestre em Administração no programa de Pós-Graduação em Administração de Organizações.

Aprovada em:

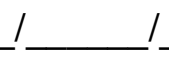

Banca Examinadora

Prof.(a) Dr.(a):

Instituição: Assinatura:

Prof.(a) Dr.(a):

Instituição: Assinatura:

Prof.(a) Dr.(a):

Instituição: Assinatura: 


\section{AGRADECIMENTOS}

Primeiramente, gostaria de agradecer à minha orientadora, professora Simone Galina, pela oportunidade que me concedeu de ingressar nesse programa de mestrado e, principalmente, por todo o conhecimento que me foi transmitido durante esse dois anos de convivência.

Quero agradecer, também, aos professores Edgard Morforte Merlo e André Lucirton Costa pela participação em minha banca de qualificação e pelas considerações que foram feitas sobre esse trabalho naquele momento e muito colaboraram para o desenvolvimento do mesmo.

Não posso deixar de lado todos os outros professores e funcionários da Faculdade de Economia, Administração e Contabilidade de Ribeirão Preto com quem tive contato durante a realização desse trabalho, que se mostrou extremamente árduo, mas ao mesmo tempo prazeroso.

Às empresas que foram entrevistadas e cederam importantes informações, sem as quais essa dissertação não teria a mesma riqueza de conteúdo.

Por fim, quero agradecer à minha família pelo incentivo que me foi dado para que eu conseguisse vencer mais essa etapa da minha formação pessoal e profissional. 


\section{RESUMO}

FERNANDES, Danilo Benedini de Mello. O Brasil no contexto da internacionalização de P\&D e na disputa pelo investimento estrangeiro das empresas transnacionais. 116 f. Dissertação (mestrado), Faculdade de Economia, Administração e Contabilidade de Ribeirão Preto, Universidade de São Paulo, Ribeirão Preto, 2008.

A globalização propiciou que novas estruturas de empresas tomassem forma. Visando ampliar seus mercados, as maiores companhias do mundo começaram a internacionalizar suas atividades.

As primeiras atividades a serem realizadas fora do país de origem foram as mais simples, como produção, comercialização e distribuição, no entanto, graças ao avanço da tecnologia, ações mais nobres puderam ser realizadas em outras regiões.

Essas mudanças estruturais forçaram as empresas multinacionais a ampliar suas fronteiras tecnológicas, passando agora a pesquisar e desenvolver produtos e processos para o mercado global, mas sempre dando o merecido destaque às peculiaridades regionais que muitas vezes decidem quem terá sucesso.

A força que a internacionalização das atividades de Pesquisa e Desenvolvimento tomou e sua importância tanto para o crescimento da companhia como para o desenvolvimento do país que recebe investimentos destinados a esse fim merecem ser estudadas. Com isso o objetivo desse trabalho é comparar o grau de internacionalização das atividades de $\mathrm{P} \& \mathrm{D}$ nas subsidiarias das empresas estrangeiras localizadas no Brasil com aquelas localizadas na Índia e na China através de indicadores de C\&T.

Palavras-chaves: Indicadores de $\mathrm{C} \& \mathrm{~T}$, internacionalização de $\mathrm{P} \& \mathrm{D}$, investimento direto estrangeiro, patentes e dado bibliométricos. 


\begin{abstract}
FERNANDES, Danilo Benedini de Mello. Brazil in the context of the internationalization of R\&D and in the dispute for the foreign investment of the companies. $116 \mathrm{f}$. Dissertation (master's degree), College of Economy, Administration and Accounting of Ribeirão Preto, Universidade de São Paulo, Ribeirão Preto, 2008.
\end{abstract}

The globalization propitiated that new structures of companies took form. Aiming at success in new markets, the biggest companies of the world started to internationalize its activities.

The first activities to be made through of the native country ware simple, as production, commercialization and distribution, however, with the advance of the technologies, nobler actions could have been carried through in other regions.

These structural changes forced the multinationals companies to extend its technological borders, passing to search and to develop products and processes for the global market, but giving the deserved emphasis to the regional peculiarities that many times decide who will have success..

The internationalization of the activities of Research and Development and its importance for the growth of the companies and for the development of the country that receives investments deserve to be studied. The objective of this dissertation is to compare the degree of internationalization of the activities of R\&D in branch offices of foreign companies located in Brazil with those located in India and China using Science and Technology data.

Keywords: Science \& Technology data, R\&D internationalization, foreign direct investment, patents and bibliometric data. 


\section{SUMÁRIO}

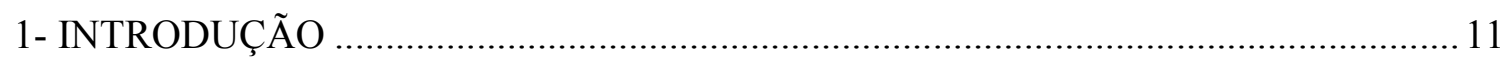

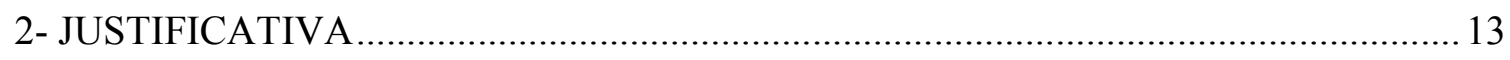

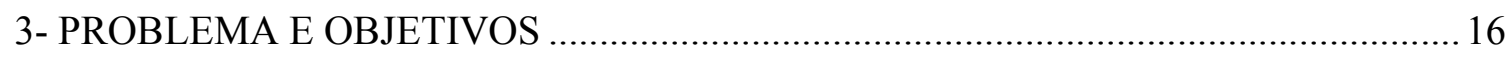

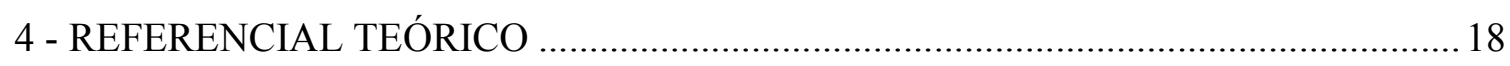

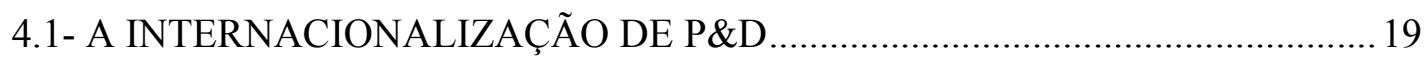

4.1.1- BENEFÍCIOS PARA O PAÍS HOSPEDEIRO...............................................23

4.1.2- ADOÇÃO DE POLÍTICAS DE ATRAÇÃO ………………………………....24

4.1.3- TIPOS DE UNIDADE FORA DO PAÍS DE ORIGEM ………………….......27

4.2- INDICADORES DE CIÊNCIA E TECNOLOGIA …………………………….......33

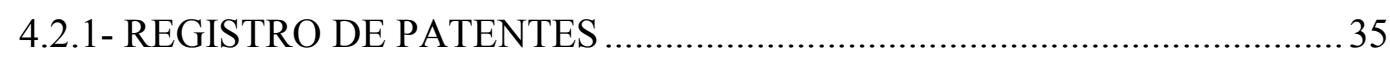

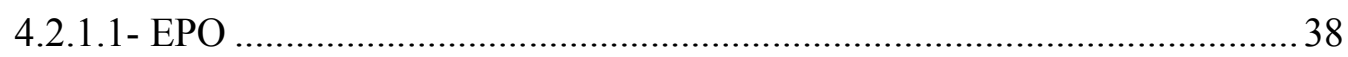

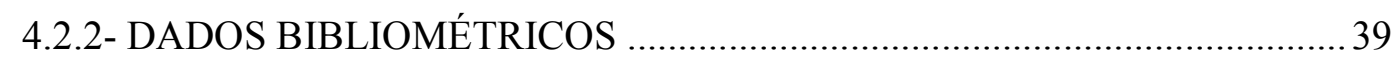

4.2.2.1 - SCIENCE CITATION INDEX................................................................ 40

4.3- PAISES EM DESENVOLVIMENTO E A DISPUTA PELO IDE .........................42

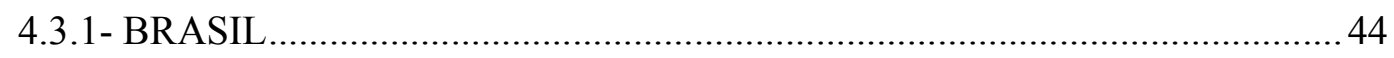

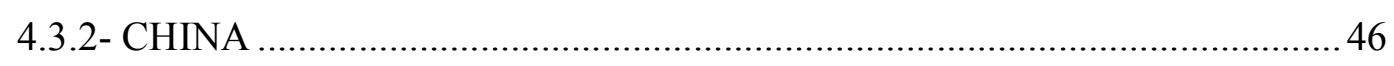

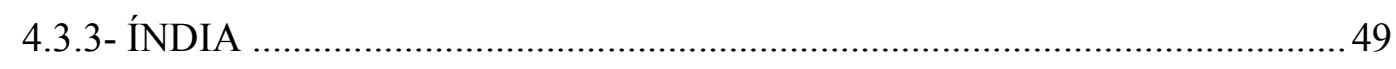

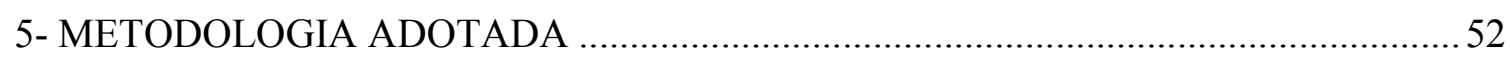

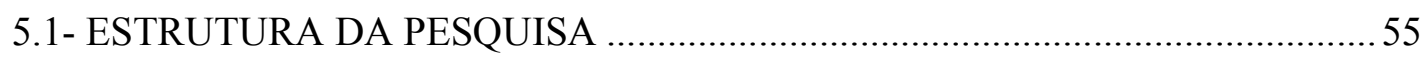

5.2- COLETA DE DADOS: MÉTODO E INSTRUMENTOS .......................................56

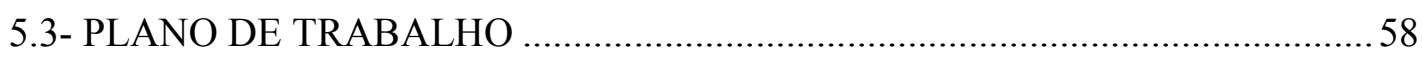


6 - RESULTADOS 61

6.1 - A EVOLUÇÃO DA SITUAÇÃO DAS EMPRESAS SELECIONADAS NOS PERIODOS DE ESTUDO

6.2 - ÁREAS DE CONHECIMENTO: PATENTES X ARTIGOS .83

6.3 - AS POLITICAS DE PATENTEAMENTO DAS EMPRESAS

MULTINACIONAIS PARA AS SUBSIDIÁRIAS LOCALIZADAS NO BRASIL .. 98

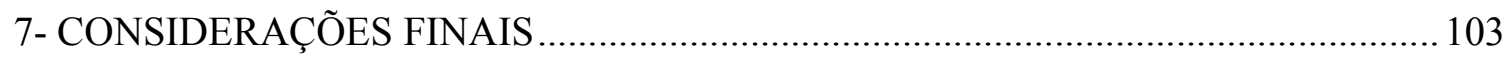

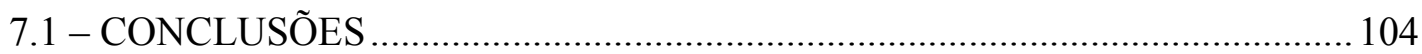

7.2 - LIMITAÇÕES DO ESTUDO E SUGESTÃO DE NOVAS PESQUISAS....... 108

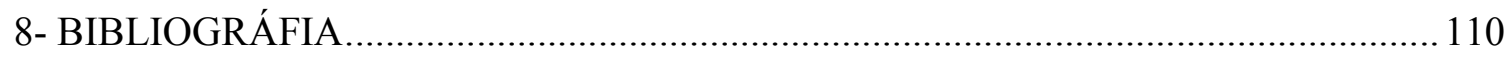

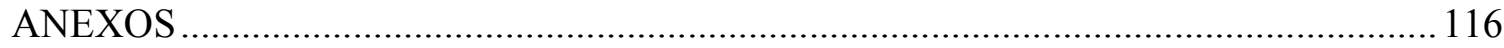




\section{LISTA DE TABELAS}

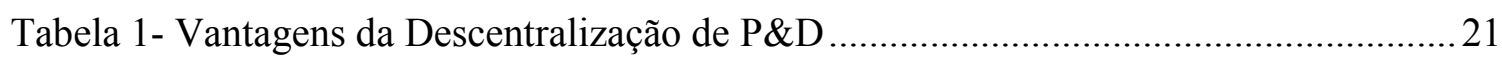

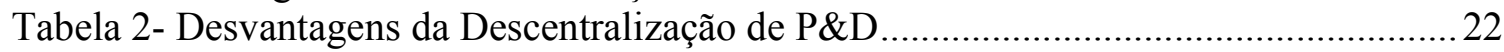

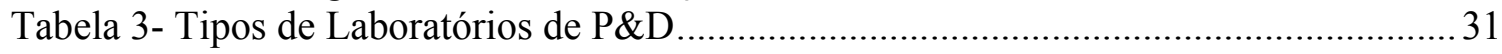

Tabela 4 - 20 maiores recebedores de ide entre os países em desenvolvimento ................... 43

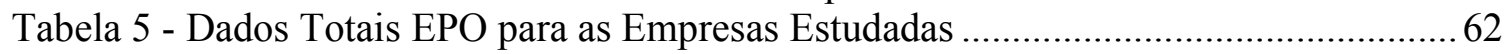

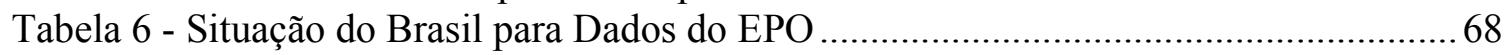

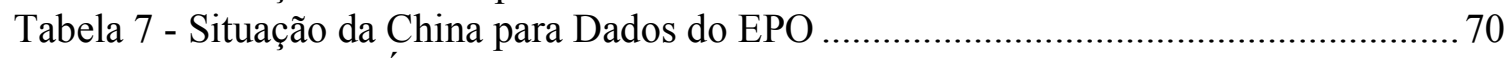

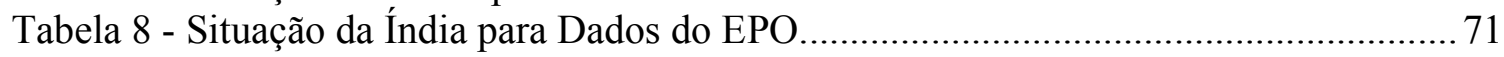

Tabela 9 - Dados Totais SCI para as Empresas Estudadas ................................................. 73

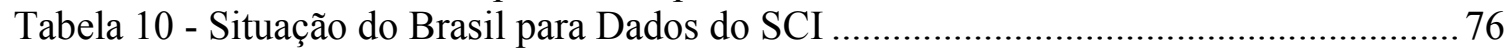

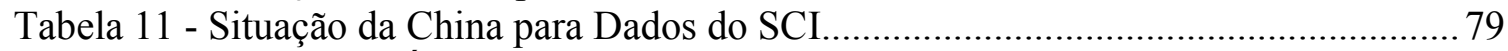

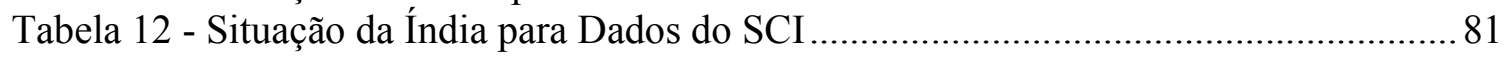

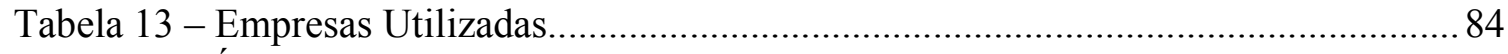

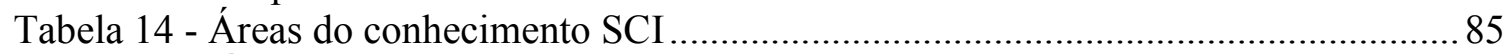

Tabela 15 - Áreas do conhecimento baseadas na classificação internacional de patentes .. 85

Tabela 16 - Relação entre Artigos e Patentes no Brasil ( $1^{\circ}$ período ) ....................................87

Tabela 17 - Relação entre Artigos e Patentes no Brasil ( $2^{\circ}$ período ) ................................... 88

Tabela 18 - Relação entre Artigos e Patentes na Índia ( $1^{\circ}$ período ) ................................... 89

Tabela 19 - Relação entre Artigos e Patentes na Índia ( $2^{\circ}$ período ) ....................................90

Tabela 20 - Relação entre Artigos e Patentes na China ( $1^{\circ}$ período ) ......................................99

Tabela 21 - Relação entre Artigos e Patentes na China ( $2^{\circ}$ período ) ................................... 93

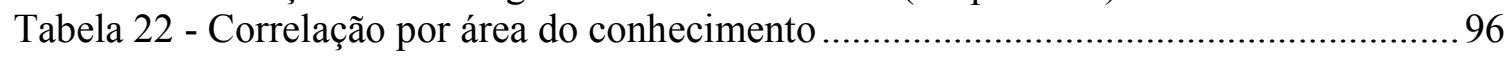

Tabela 23- Modelo de tabela para formatação dos dados coletados ................................. 116

Tabela 24- Empresas escolhidas para análise de patentes e dados bibliométricos............. 117

Tabela 25- Empresas pré-selecionadas para estudos de caso ........................................... 121

\section{LISTA DE GRÁFICOS}

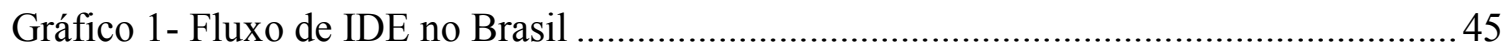

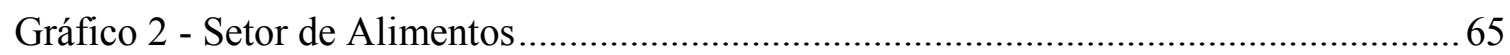

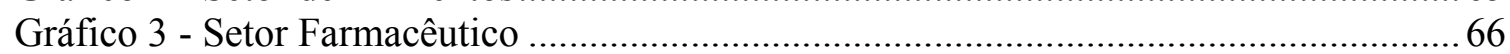

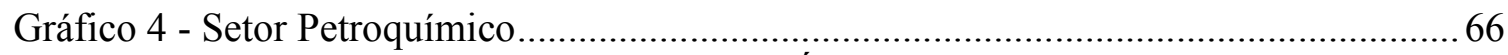

Gráfico 5 - Evolução da Correlação para Brasil, Índia e China .......................................... 95

Gráfico 6 -Políticas de patenteamento para o Brasil ................................................................99 


\section{1- INTRODUÇÃO}

Um dos aspectos importantes da chamada globalização empresarial inclui a função tecnológica das grandes empresas multinacionais (EMNs). Tomando-se a noção de globalização sugerida por Sachwald (1994), como “a integração funcional de atividades geograficamente dispersas das empresas multinacionais", percebe-se que também as atividades tecnológicas, em particular as de pesquisa e desenvolvimento (P\&D), começam a ser planejadas e conduzidas em escala mundial por essas empresas em busca de, entre outras coisas, aumento de capital e ganho de participação de mercado em paises que apresentam potencial de crescimento. A ampla literatura sobre o tema "internacionalização da P\&D" comprova o alto calibre que o fenômeno vem tomando, a diversidade de seus determinantes e a importância de seus efeitos sobre os paises que recebem novos investimentos e suas estruturas econômicas.

Um segundo ponto a ser levado em consideração refere-se ao papel que as filiais brasileiras das EMNs podem desempenhar nesse novo contexto da tecnologia globalizada. De acordo com o estudo da UNCTAD (2004), China e Índia claramente se destacam, entre os países em desenvolvimento, como os principais destinos do investimento em P\&D das EMNs. No entanto, ainda que em menor proporção, as subsidiarias brasileiras têm recebido parcelas cada vez mais relevantes do total investido em P\&D, afinal o Brasil também oferece uma série de condições vantajosas para disputar esses investimentos.

Deste modo, o projeto se propõe a avaliar como e onde estão sendo aplicados os recursos destinados a $\mathrm{P} \& \mathrm{D}$ pelas EMNs e fazer uma analise comparativa do Brasil com as duas principais fontes de investimentos: China e Índia. Para tal, serão levantados 
indicadores de Ciência e Tecnologia $(C \& T)$ que podem ser utilizados para a medição da participação de cada país na quota de investimentos das EMNs.

O principal desses indicadores que será abordado se refere a patentes requeridas, em âmbito nacional ou global, fora da matriz, ou seja, qual a nacionalidade da subsidiaria que foi responsável pelo desenvolvimento do novo produto ou processo. Desta forma, é possível estimar qual a importância dada por cada empresa para cada mercado e qual a participação de cada filial nos recursos destinados a $\mathrm{P} \& \mathrm{D}$ da companhia, tido que investimentos recebidos devem ser diretamente proporcionais ao retorno obtido em forma de novidades relevantes para a EMN.

Considerando uma possível fragilidade dos resultados quando se tem apenas as análises estatísticas das patentes, é necessário combiná-los com outros indicadores de C\&T (LACERDA, 2004; GREGORY; OLIVEIRA, 2005). Assim, serão utilizados no estudo, informações bibliométricas provenientes do SCI (Science Citation Index), editado pelo instituto norte-americano ISI (Institute for Scientific Information). Isso permitirá avaliar a importância das pesquisas realizadas pelas empresas estudadas na geração de conhecimento, e ainda analisar o envolvimento dessas empresas com universidades e centros de pesquisa.

Desta forma, serão combinadas neste trabalho dados quantitativos obtidos através de dois dos indicadores de ciência e tecnologia mais utilizados pela academia: números de patentes e estudos bibliométricos.

Espera-se, com isso, analisar o desenvolvimento do Brasil nos últimos anos no que tange a posição das EMNs em relação à aposta deste país como um bom destino para seus investimentos em P\&D. O grande foco está na criação de um ambiente mais favorável, principalmente no estado de São Paulo, para o recebimento de investimentos estrangeiros 


\section{2- JUSTIFICATIVA}

O Brasil, nos últimos anos, vem recuperando a condição de ser um dos principais destinos mundiais de investimento direto estrangeiro (IDE), no período 1991-1996, a média anual de IDE recebido foi de US\$ 3,6 bilhões, crescendo significativamente a partir de 1997 até atingir o volume de US\$ 32,8 bilhões em 2000. Mesmo com a diminuição da entrada de IDE depois desse recorde, a posição brasileira no ranking não se alterou expressivamente e o país continuou sendo, depois da China, o país em desenvolvimento que mais recebe IDE (UNCTAD, 2003).

As políticas nacionais têm papel decisivo na atração de IDE, acaba sendo desenvolvida uma relação semelhante à relação de mercado, na qual as EMNs são como consumidores e os paises têm função de conquistar esses clientes e fidelizá-los para conseguir atrair uma parcela maior e mais qualificada de seus investimentos em P\&D.

Neste cenário de competição cada vez mais intensa por investimentos, os paises desenvolvidos têm adotado políticas de pró-mercado (market-friendly), sem com isso deixar totalmente de tomar medidas de favorecimento ao IDE. Os paises em desenvolvimento, por sua vez, precisam desenvolver ainda mais fortemente essas políticas, uma vez que suas estruturas de mercado são menos consolidadas e suas bases institucionais e de infra-estrutura (inclusive de C\&T) relativamente precárias.

Diante desse panorama, Índia e China são exemplos de países em desenvolvimento fortemente empenhados em atrair atividade de P\&D para seus territórios. Merecem destaque os fatos de no último Fórum Econômico Mundial, em Davos na Suíça, a Índia investir milhões para se promover como um bom destino para investimentos junto aos altos 
executivos que estavam presentes, e da China realizar várias ações para valorizar sua cultura e cativar os grandes empresários.

Hoje os dois paises detêm $13,9 \%$ de todos os centros de pesquisa e desenvolvimento de EMNs fora do país de origem. Em 1990, a participação conjunta era de apenas 3,4\%.

Estudo realizado por Basu (2003) demonstra que em fevereiro de 2003 havia uma centena de centros de P\&D de multinacionais na Índia, desses, mais de 70\% haviam sido criados nos últimos cinco anos. Embora a maior parte desses centros esteja voltada para atividades de desenvolvimento e adaptação de produtos às condições locais, existem alguns centros globais de P\&D responsáveis por atividades mais complexas. Um exemplo é o centro de P\&D da GE em Bangalore, o maior que a empresa mantém fora dos EUA, empregando um total de 1.600 pessoas.

A China tem sido ainda mais agressiva em sua política de atração de atividades tecnológicas. De acordo com um funcionário do MOFTEC (Ministry of Foreign Trade and Economic Cooperation), "o número de instituições de P\&D criadas por multinacionais na China irá dobrar nos próximos cinco anos" (Business Alert, China, 2003). Exemplo significativo desse fluxo recente de investimentos estrangeiros em tecnologia é o estabelecimento do centro de pesquisas do Bell Labs em Pequim. De acordo com o anúncio, em março de 2000, “é a primeira vez em sua história que o Bell Labs estabelece um laboratório de pesquisa fora dos EUA. Este laboratório será um centro de excelência técnica e inovação na tradição do Bell Labs. Irá realizar pesquisa básica em áreas como rede de dados, software, comunicações, redes óticas, ciência da computação e matemática aplicada" (Bell Labs - Research in China, 2000).

Mesmo estando aparentemente atrás da Índia e da China quanto à atração de unidades de $\mathrm{P} \& \mathrm{D}$, o Brasil possui como ponto a seu favor o fato de, comparativamente, 
possuir uma quantidade de EMNs aqui estabelecidas há tempo superior à dos outros paises. Isso traz à tona atividades tecnológicas voltadas para adaptação e desenvolvimento de produtos e processos já desenvolvidos no Brasil com histórico de sucesso. Este é um ponto de partida importante para potenciais aumento e melhoria das atividades tecnológicas dessas empresas.

Uma análise comparativa mais completa e confiável, envolvendo Brasil, Índia e China, é de extrema importância para situar o país frente às duas principais forças da atualidade. Neste sentido, essa dissertação poderá ajudar na formulação das estratégias de gestão e atração dos laboratórios de P\&D das EMNs, e conseqüentemente, gerar mais destaque para o Brasil no panorama de descentralização dos investimentos em P\&D por parte das EMNs. 


\section{3- PROBLEMA E OBJETIVOS}

Esta dissertação foi estruturada para buscar responder o seguinte problema de pesquisa que surgiu durante a pesquisa:

Qual a representatividade do $\mathrm{P} \& \mathrm{D}$ das subsidiarias das empresas estrangeiras no Brasil comparado-as às subsidiarias das mesmas na Índia e na China em termos de resultados expressos em indicadores de C\&T?

Dessa forma, o trabalho proposto tem o seguinte objetivo:

Realizar análises comparativas das empresas estrangeiras localizadas no Brasil em relação às mesmas localizadas na Índia e na China levando em consideração indicadores de C\&T que reflitam a internacionalização das atividades de P\&D nas subsidiarias dessas empresas.

Para atender ao objetivo principal, esta dissertação tem os seguintes objetivos específicos:

1 - Comparar a evolução dos indicadores - patentes e dados bibliométricos das empresas selecionadas nos dois períodos de coleta dos dados em cada um dos países estudados; 
2 - Analisar se as empresas da amostra solicitam patentes nas mesmas áreas de conhecimento em que seus funcionários publicam artigos científicos nos três países estudados;

3 - Investigar quais são as políticas voltadas ao patenteamento de empresas multinacionais para as subsidiárias localizadas no Brasil; 


\section{4 - REFERENCIAL TEÓRICO}

Neste capítulo serão abordados temas relevantes ao estudo proposto e que podem dar maior embasamento para as analises realizadas. O referencial bibliográfico está dividido em três seções mais amplas que se subdividem em outras mais diretas e objetivas.

A primeira parte do capítulo está concentrada na internacionalização das funções de pesquisa e desenvolvimento realizadas pelas empresas multinacionais. Essa discussão tem seqüência com o levantamento da situação atual desse novo paradigma, a enumeração das vantagens trazidas para os paises que recebem investimentos em $\mathrm{P} \& \mathrm{D}$ de empresas estrangeiras e a classificação usada pela literatura para as unidades das empresas localizadas fora do país da matriz.

A segunda seção desta dissertação trata dos indicadores de Ciência e Tecnologia que foram utilizados no estudo e expõe as vantagens e desvantagens do emprego de cada um deles. Feito isso, o foco do trabalho fica nas bases de dados de onde foram coletadas as informações utilizadas na parte quantitativa do trabalho.

A última seção deste referencial teórico descreve a disputa dos paises em desenvolvimento pelos investimentos das companhias estrangeiras e se aprofunda nos três paises que estão sendo estudados: Brasil, Índia e China. 


\section{1- A INTERNACIONALIZAÇÃO DE P\&D}

Antes de qualquer aprofundamento no tema da internacionalização propriamente dita é preciso adotar uma definição clara e padronizada do significado de Pesquisa e Desenvolvimento (P\&D) e de suas três vertentes para o bom andamento desse trabalho. Segundo o Manual Frascati (1993), entende-se por Pesquisa e Desenvolvimento, quaisquer atividades que compreendem o trabalho criativo sistemático com o intuito de ampliar o conhecimento e o seu uso na busca de novas aplicações. Estas podem ser divididas em três:

- Pesquisa básica - trabalho experimental ou teórico realizado primordialmente para adquirir novos conhecimentos sobre os fundamentos de fatos ou fenômenos observáveis, sem o propósito de qualquer aplicação ou utilização;

- Pesquisa aplicada - investigação original, realizada com a finalidade de obter novos conhecimentos, mas dirigida, primordialmente, a um objetivo prático;

- Desenvolvimento experimental - trabalho sistemático, apoiado no conhecimento existente, adquirido por pesquisas ou pela experiência prática, que é dirigido para a produção de novos materiais, produtos ou equipamentos, para a instalação de novos processos, sistemas ou serviços, ou para melhorar aqueles já produzidos ou instalados.

Ciente desse conceito, a literatura internacional que trata do tema deixa claro que as atividades de P\&D de Empresas Multinacionais estão sendo cada vez mais descentralizadas, passando a ser realizada em outros países que não o de origem da matriz. Ainda que outras atividades da empresa, como produção, comercialização e distribuição, sejam bem mais internacionalizadas do que as atividades de tecnologia, a rapidez e a força que a internacionalização da $\mathrm{P} \& \mathrm{D}$ vem tomando merecem ser investigadas. (Archibugi e Iammarino, 1999; Bartlett e Ghoshal ,1998; Galina e Bortoloti,2004) 
Tradicionalmente essas companhias operavam por meio de estruturas centralizadas de $P \& D$, o que facilitava a criação da inovação no país da matriz seguida por sua disseminação entre as diversas subsidiárias. Entretanto, como salientam os autores, na última década o panorama competitivo sofreu importantes mudanças, e, por conta disso, as empresas multinacionais foram forçadas a repensar suas estratégias de P\&D.

Buscando aproveitar oportunidades de mercado e vantagens concedidas por determinados paises, a internacionalização das EMNs tem se caracterizado, de modo especialmente intenso nas duas últimas décadas.

Muitos estudos mostram que as EMNs estão investindo mais no desenvolvimento em suas filiais (OECD, 1998; Dalton e Serapio, 1999; Granstrand, 1999). O estudo de Dalton e Serapio (1999) sobre descentralização de P\&D mostra que os investimentos de companhias estrangeiras nos EUA triplicaram entre 1987 e 1997, passando de US\$ 6,5 bilhões para US\$ 19,7 bilhões, enquanto que os investimentos em P\&D no exterior de empresas americanas também cresceram, passando de US\$ 5,2 bilhões em 1987 para US\$ 14,1 bilhões em 1997, o que marcou uma tendência mundial.

Também sobre o crescimento da internacionalização de P\&D, informações recentes retiradas do U.S. Department of Commerce (Bureau of Economic Analysis - BEA), retratam o aumento dos gastos em P\&D de filiais de empresas americanas em outras localidades. Esses gastos passaram de US\$ 14,6 bilhões em 1998, para US\$ 21,1 bilhões em 2002.

Com base nesses acontecimentos, Bartlett e Ghoshal (1998) desenvolveram um novo modelo de empresa chamado de transnacional. Nesse modelo, o foco das EMNs é a superação dos desafios competitivos de uma economia analisada de forma global, buscando adquirir eficiência para poder competir em escala global e receptividade local para obter flexibilidade. O poder de escolha para optar entre centralizar ou descentralizar ativos é 
substituído por um processo de decisões seletivas. O resultado desse processo é uma disposição de empresa diferenciada, com ativos e capacidades distribuídos e recursos descentralizados.

O processo de internacionalização não é caracterizado apenas por vantagens para todos os envolvidos, há também desvantagens que devem ser levadas em consideração no planejamento da estrutura do P\&D em será adotado. Desta forma, com base nos trabalhos de Duysters \& Hagedoorn (1996), Vasconcellos \& Vasconcellos (1994) e Stal (2002) foi elaborado a seguinte tabela:

Tabela 1- Vantagens da Descentralização de P\&D

1) O número de fontes de conhecimento é maior com as empresas estabelecendo centros de P\&D em diferentes locais, assim há disponibilidade de absorção de conhecimento gerado por universidades, fornecedores e competidores em diversos paises.

2) È possível dar atenção especial às necessidades locais mais rapidamente e com a competição global, cada vez mais a habilidade de vencer em um dado mercado depende da capacidade de adaptar o produto.

3) Centros de P\&D locais permitem apoio técnico aos clientes de forma mais rápida e qualificada.

4) Com a descentralização de $P \& D$, as empresas fazem uso de incentivos oferecidos pelos governos locais (infra-estrutura, redução de impostos, facilidade na importação de insumos). Este aspecto foi estudado por Leyden e Link (1993) em 23 países, concluindo pela eficácia desta política. 
5) Disponibilidade de mão de obra qualificada a custo menor. A Índia, por exemplo, é sempre lembrada por possuir especialistas em software de alta qualidade e a um custo baixo.

Tabela 2- Desvantagens da Descentralização de P\&D

1) Perda de economias de escala em equipamentos e recursos humanos.

2) Risco de duplicações de esforços.

3) Dificuldade de uma visão integrada de P\&D.

4) Maior dificuldade para a realização de parcerias estratégicas globais com fornecedores, clientes e concorrentes.

Mesmo com toda a tecnologia já desenvolvida e com a eficiência dos sistemas de comunicação e informação, a administração de unidades de P\&D distantes geograficamente não é simples (GERYBADZE; REGER, 1999). A tecnologia pode, sim, minimizar a necessidade de uma mesma localidade para essas atividades, mas não resolve os problemas relacionados à confiança, espírito de time e transferência de conhecimento tácito (GASSMAN; VON ZEDWITZ, 2003).

É preciso destacar, entretanto, que mesmo com essa forte tendência global para a descentralização, esse processo ainda não é uma convergência geral. É mais um processo isolado em que as empresas ficam testando qual configuração (atividades tecnológicas mais ou menos centralizadas) é a mais condizente às suas necessidades e objetivos. Para 
Archibugi e Iammarino (1999), as vantagens de centralizar ou descentralizar atividades tecnológicas dependem do país em questão, do tipo de empresa, dos produtos e das tecnologias envolvidas.

\subsection{1- BENEFÍCIOS PARA O PAÍS HOSPEDEIRO}

Ainda existe polêmica a respeito do que é de fato a tão falada globalização, no entanto é observada, nos trabalhos que envolvem esse tema, uma plausível aceitação entre os autores de que o termo refere-se à significativa expansão do comércio internacional, dos fluxos de capitais e, em um segundo momento, da estrutura produtiva da empresa.

Partindo-se desse precedente, conclui-se que os efeitos da globalização e o aumento da concorrência têm transformado as estruturas e a forma de trabalhar das empresas. As fusões e aquisições de outras companhias retratam esse fenômeno internacional que cresceu muito nos últimos anos, especialmente entre os países desenvolvidos. Essas atividades, antes pouco freqüentes, têm sido agora a principal razão dos investimentos diretos estrangeiros em outras localidades (LACERDA, 2004; GERYBADZE E REGER 1999; GOMES 2003).

Segundo Lacerda (2004), cerca de 90\% dos investimentos diretos estrangeiros realizados mundialmente estão diretamente relacionados à compra e venda de empresas já existentes.

Gregory e Oliveira (2005) listaram os dez países que mais investiram fora de suas fronteiras em 2003: Estados Unidos, Japão, Países Baixos, França, Bermudas, Ilhas Cayman, Espanha, Ilhas Virgens Britânicas, Alemanha e Itália. 
Alem de serem os maiores investidores em outros paises, os principais receptores de IDE também são os países desenvolvidos, no entanto, os processos de ajustes nas economias locais efetuados nos países em desenvolvimento vêm motivando o interesse dos detentores de capital.

Apesar dos esforços dos governos, a geração de novas tecnologias em países em desenvolvimento ainda é pouco significante (ARCHIBUGI; PIETROBELLI, 2003). O mesmo estudo revela que, nesses países, o grande empecilho não é a falta de talentos individuais científicos e tecnológicos, mas a falta de infra-estrutura apropriada.

Justamente por essas razões, pouco mais de 1\% das atividades tecnológicas geradas por Multinacionais do "norte" provêm de suas subsidiárias instaladas no "sul" (ARCHIBUGI; PIETROBELLI, 2003). Em outras palavras, países em desenvolvimento recebem apenas os restos das atividades de pesquisa das EMN.

\subsection{2- ADOÇÃO DE POLÍTICAS DE ATRAÇÃO}

A discussão sobre os principais determinantes da globalização da $\mathrm{P} \& \mathrm{D}$ não pode deixar de incluir entre os fatores mais relevantes as políticas de atração adotadas pelos paises em questão.

Hakanson e Nobel (1993) destacam o papel dos incentivos políticos para atrair determinados tipos de $\mathrm{P} \& \mathrm{D}$, o estudo relaciona tal importância às atividades que controladas pelo governo, como telecomunicações e equipamentos militares.

Contudo, é necessário um entendimento mais amplo do que seriam essas políticas públicas para atração de atividades tecnológicas. É preciso cuidado para não minimizar a importância dessas medidas e considerar apenas incentivos financeiros. Muitas vezes, os 
incentivos são um fator decisivo, mas apenas no sentido de desempatar uma disputa acirrada pela decisão de para qual país determinado investimento deve ir. Os incentivos não decidem sozinhos uma disputa, até porque podem ser pouco estáveis ou simplesmente transitórios.

É preciso, então, fazer uso das políticas de atração através de uma perspectiva maior, partindo-se da formação de recursos humanos compatíveis com as necessidades da companhia almejada, passando por investimentos em infra-estrutura e em políticas do Estado, pela divulgação do país com bom destino de investimentos estrangeiros. Só depois de ter sucesso nesses passos deve-se chegar a incentivos financeiros.

Com a perspectiva de um cenário de competição cada vez mais intensa por investimentos em P\&D, a conformação e a eficácia das políticas públicas adotadas pode ser o fator decisivo para separar aqueles que terão sucesso e os que não o terão.

Há algumas medidas de caráter amplo que podem favorecer os investimentos em P\&D de EMNs: É o caso dos investimentos em infra-estrutura ou dos investimentos na formação de doutores e mestres.

Todavia, os fatores que atraem as EMN são valorizados de modo diferente por empresas de diferentes setores e com diferentes estratégias, compete, então, à política desenvolvida pelo governo local definir quais investimentos são prioritários e quais deles o país deve prioritariamente tentar atrair. Para uma empresa do setor farmacêutico, por exemplo, uma legislação adequada de proteção à propriedade intelectual possivelmente é um fator muito mais importante na decisão de um investimento em P\&D em determinado país do que seria para uma empresa de auto-peças. Da mesma forma, duas companhias com áreas de atuação similares podem avaliar de formas diversas a importância de se contar com 
pesquisadores que costumam publicar em grandes revistas internacionais, isso por apresentarem diferentes estratégias de internacionalização da pesquisa.

Os recentes estudos sobre os fatores que mais atraem o P\&D das empresas internacionalizadas são pouco conclusivos, até mesmo porque cada caso é um caso nesse panorama. Para tanto, é preciso entender melhor a relação entre as características setoriais, as estratégias globais para $\mathrm{P} \& \mathrm{D}$ individuais de cada empresa e os fatores de atração de atividades tecnológicas.

Com base na literatura sobre internacionalização de $P \& D$ e principalmente em Pearce (1999), alguns elementos básicos das políticas de atração estão expostos:

Medidas de caráter amplo são bem-vindas, porém não são suficientes. Apenas aumentar a formação de mestres e doutores, pode não trazer os resultados esperados. Para atrair alguns tipos especiais de investimentos, será preciso definir antes de qualquer outra coisa em que áreas é preciso aumentar a formação de profissionais. A política precisa atuar ativamente, identificando e escolhendo alvos específicos, até mesmo no que diz respeito a uma empresa especifica. Partindo-se de um alvo pré-definido, algumas ações devem ser conduzidas sob medida.

É preciso desenvolver os indicadores que são levados em consideração pelas EMN para cada fator referente à atração. Desta forma o país em questão já garante uma vitrine para se expor e salta aos olhos dos gestores das grandes companhias internacionais. No regime de propriedade intelectual, por exemplo, deve-se esforçar para conseguir 
os melhores indicadores que avaliam o grau de proteção oferecido pela legislação.

É necessário acompanhar o trabalho dos "países concorrentes" com atenção. O monitoramento das políticas de promoção de atividades tecnológicas e atração de IDE que os outros países estão adotando é essencial para o sucesso das medidas criadas e aplicadas.

As políticas que já estão sendo utilizadas pelo país interessado requerem avaliações periódicas e conclusivas sobre seus custos e sua verdadeira eficácia para atrair IDE em P\&D.

\subsection{3- TIPOS DE UNIDADE FORA DO PAÍS DE ORIGEM}

Vários estudos já se propuseram a analisar os tipos de unidades tecnológicas de empresas multinacionais localizadas no exterior, diversos pesquisadores publicaram os resultados e suas considerações. Geralmente, as subsidiarias são classificadas de acordo com suas características e funções desempenhadas dentro do plano de negócios da empresa.

Ronstadt (1978), depois de estudo detalhado, identifica quatro tipos de unidade de P\&D fora da matriz:

1. Unidade de transferência de tecnologia. É voltada para a solução de problemas técnicos, geralmente está ligada às unidades de produção, aparece em um estágio inicial do ciclo de vida dos produtos;

2. Unidade de tecnologia endógena. São unidades que buscam desenvolver produtos novos ou melhorados para os mercados locais, não há, necessariamente, dependência da tecnologia da matriz; 
3. Unidade de tecnologia global. É voltada para a criação de novos produtos ou para o desenvolvimento de processos mais estruturados. As novas “descobertas" também podem ser aplicadas em outros mercados e as principais tecnologias de curto prazo para a empresa são desenvolvidas em uma planta como essa;

4. Unidade de tecnologia corporativa. Tem o objetivo de gerar novas tecnologias de longo prazo ou de natureza exploratória para a companhia, preza pela proteção da posição competitiva da empresa. Por serem unidades de pesquisa básica, esses laboratórios não se localizam próximos às unidades de produção, isso é feito para que não haja preocupação com os problemas de curto prazo.

Behrman e Fischer (1980) também estudaram os modos de surgimento de uma unidade de P\&D descentralizada e as suas funções. Para esses autores, há três formas possíveis para o surgimento de unidades de P\&D fora da matriz:

a) Por evolução (um tipo de unidade evolui, de acordo com as necessidades corporativas, e se torna outra mais sofisticada tecnologicamente),

b) Criação direta,

c) Aquisição (compra de uma unidade de outra empresa).

Pearce (1989) também discute a natureza da Pesquisa e do Desenvolvimento realizados pelas filiais das grandes empresas, classificando-as em pesquisa básica, aplicada ou desenvolvimento. Ele ainda escreveu a respeito da orientação das atividades comerciais das filiais de empresas transnacionais. Essas unidades podem ser:

- Voltadas ao mercado de origem da empresa - filiais apenas dão apoio às matrizes, havendo, assim, pouca atividade de P\&D; 
- Voltadas ao mercado local - subsidiárias procuram atender o mercado local, nesse caso, as atividades de P\&D auxiliam na adaptação de produtos e processos ao mercado local. Essas atividades objetivam tornar as filiais mais competitivas;

- Voltadas ao mercado global - subsidiárias integradas as ações do grupo e atendem mercados diversos pelo mundo. As atividades de P\&D, neste caso, acontecem em elevado grau.

Através de uma pesquisa do tipo "survey" envolvendo 145 filiais de grandes empresas localizadas na Europa, Papanastassiou e Pearce (1994a) identificaram as principais diferenças na atuação de subsidiárias de multinacionais no que diz respeito a $\mathrm{P} \& \mathrm{D}$. $\mathrm{O}$ trabalho mostrou três tipos diferentes de pesquisa que são realizadas nos laboratórios dessas subsidiárias:

1- adaptação de produto ou processo;

2- desenvolvimento de novo produto;

3- criação de conhecimento científico mais amplo para ser gerido pela cúpula da empresa.

Em outro trabalho publicado no mesmo ano, Papanastassiou e Pearce (1994b) baseiamse no trabalho de Hood e Young (1982) e constroem um modelo para classificar os laboratórios das multinacionais em três categorias: Laboratório de Apoio (LA), Laboratório Localmente Integrado (LLI) e Laboratório Internacionalmente Interdependente (LII). Para que possa ser estabelecida uma relação lógica entre os tipos de laboratórios e de unidade descentralizada, estas também foram enumeradas: 1) Réplicas Miniaturas Truncadas (RMT), sendo uma reprodução da matriz que deixa de executar apenas certas funções (por exemplo, P\&D); 2) Filiais Especializadas (FE), tem portfólio de produtos reduzido e 
participação mais efetiva na estratégia global da matriz; 3) Filiais com Mandato Mundial ou Regional (FMM ou FMR), pode ter responsabilidade integral por P\&D de determinado produto já que tem a exclusividade para o fornecimento mundial ou regional do mesmo..

Artigo de Pearce (1999), identificou dois papéis extremamente importantes que as unidades de $\mathrm{P} \& \mathrm{D}$ podem obter. O primeiro deles diz respeito a subsidiaria produzir alguns produtos destinados a segmentos estratégicos do mercado global. Neste caso, essas unidades possuem uma relação operacional muito próxima às outras funções clássicas da companhia.

A segunda abordagem, ainda mais vanguardista, afirma que os laboratórios descentralizados de $\mathrm{P} \& \mathrm{D}$ podem vir a ocupar posições destacadas em pesquisas básicas que são interessantes para os planos de longo prazo da empresa, desde que o país de sua localização seja especializado na área do estudo pretendido, isso acontece atualmente na Índia com o setor de softwares, por exemplo.

Vale ressaltar que a estratégia tecnológica das multinacionais não é somente ligada à aplicação de seu conhecimento acumulado no ambiente competitivo atual. Há também uma necessidade de revitalização de suas tecnologias-chave, para que haja sempre geração de produtos e processos que poderão dar continuidade aos negócios e ao sucesso da empresa no longo prazo (Pearce, 1999).

Enquanto o estudo de Dunning e Narula (1995) classificou os serviços realizados pelos laboratórios de $\mathrm{P} \& \mathrm{D}$ de acordo com os diferentes tipos de Investimento recebidos, Pearce e Papanastassiou (1994a) desenvolveram um novo modelo - usando para isso questionários respondidos por subsidiárias estrangeiras que faziam pesquisa e se localizavam na Inglaterra. Desta forma, este último estudo deve refletir melhor a realidade mais recente (Gomes, 2003). 
Para Hakanson e Nobel (1993b), existem cinco tipos de unidades de P\&D, cada uma com suas características peculiares, a classificação leva em conta o motivo da instalação no país escolhido:

- Orientadas para o mercado (adaptação de produtos ao mercado local);

- Suportam a produção;

- Pesquisa básica;

- Politicamente motivadas;

- "Multi-motivos" (combinação de dois ou mais motivos).

Ainda há outro estudo, este de Archibugi e Iammarino (1999), que identificou três categorias de internacionalização de unidades focadas na inovação: a) exploração internacional da tecnologia criada em base local (a mais antiga e difundida); b) geração global de inovação; e c) cooperações tecnológicas globais. Para os autores, as três categorias podem ser complementares e não são excludentes uma das outras, ou seja, algumas empresas podem ter os três tipos de inovação.

O quadro abaixo, retirado Gomes (2003), apresenta um resumo de alguns dos estudos sobre atividades tecnológicas descentralizadas.

Tabela 3- Tipos de Laboratórios de P\&D

Fonte: Gomes, 2003

\begin{tabular}{|c|c|c|c|c|c|}
\hline \multicolumn{6}{|c|}{ Laboratórios de Pesquisa e Desenvolvimento na Literatura: uma compatibilização } \\
\hline \multirow[b]{2}{*}{ Classe } & \multirow[b]{2}{*}{ Características } & \multicolumn{4}{|c|}{ Autor } \\
\hline & & $\begin{array}{l}\text { Pearce \& } \\
\text { Papanatassiou } \\
(1999)\end{array}$ & $\begin{array}{l}\text { Dunning \& } \\
\text { Narula (1995) }\end{array}$ & $\begin{array}{l}\text { Young \& } \\
\text { Hood (1982) }\end{array}$ & \begin{tabular}{|l} 
Ronstadt \\
(1977)
\end{tabular} \\
\hline
\end{tabular}




\begin{tabular}{|c|c|c|c|c|c|}
\hline \multirow[t]{4}{*}{ Tradicional } & Nome & $\begin{array}{l}\text { LS1 } \\
\text { Adaptações do } \\
\text { produtos a } \\
\text { serem } \\
\text { produzidos ou } \\
\text { processos a } \\
\text { serem } \\
\text { utilizados }\end{array}$ & \begin{tabular}{|l} 
TIPO 1 \\
Adaptações \\
ou \\
melhoramen- \\
tos de \\
insumos \\
(material), \\
produtos ou \\
de processos
\end{tabular} & $\begin{array}{l}\text { Suporte } \\
\text { para } \\
\text { Transferênci } \\
\text { a de } \\
\text { tecnologia }\end{array}$ & $\begin{array}{l}\text { Suporte } \\
\text { para } \\
\text { Transferên- } \\
\text { cia de } \\
\text { tecnologia }\end{array}$ \\
\hline & Função & Suporte & Suporte & Suporte & Suporte \\
\hline & Abrangência & Local & Local & Local & Local \\
\hline & $\begin{array}{l}\text { Grau de } \\
\text { autonomia }\end{array}$ & Muito baixo & Baixo & Baixo & Baixo \\
\hline \multirow{4}{*}{$\begin{array}{l}\text { Regionalmente } \\
\text { Integrado }\end{array}$} & Nome & $\begin{array}{l}\text { LS2 } \\
\text { Laboratório de } \\
\text { suporte } \\
\text { integrado }\end{array}$ & $\begin{array}{l}\text { TIPO } 2 \\
\text { Pesquisa de } \\
\text { produtos ou } \\
\text { insumos } \\
\text { básicos }\end{array}$ & $\begin{array}{l}\text { Laboratório } \\
\text { localmente } \\
\text { integrado }\end{array}$ & $\begin{array}{l}\text { Unidade } \\
\text { local de } \\
\text { Tecnologia }\end{array}$ \\
\hline & Função & $\begin{array}{l}\text { Suporte com } \\
\text { inovação } \\
\text { incremental }\end{array}$ & $\begin{array}{l}\text { Suporte com } \\
\text { inovação } \\
\text { incremental }\end{array}$ & $\begin{array}{l}\text { Suporte com } \\
\text { inovação } \\
\text { incremental }\end{array}$ & $\begin{array}{l}\text { Suporte } \\
\text { com } \\
\text { inovação } \\
\text { incrementa } \\
1\end{array}$ \\
\hline & Abrangência & Regional & Local & $\begin{array}{l}\text { Local/region } \\
\text { al }\end{array}$ & Local \\
\hline & $\begin{array}{l}\text { Grau de } \\
\text { autonomia }\end{array}$ & Médio & Médio/baixo & Médio/baixo & $\begin{array}{l}\text { Médio/baix } \\
\text { o }\end{array}$ \\
\hline \multirow{4}{*}{$\begin{array}{l}\text { Internacional- } \\
\text { mente } \\
\text { Integrado }\end{array}$} & Nome & $\begin{array}{l}\text { LLI } \\
\text { Laboratório } \\
\text { localmente } \\
\text { integrado }\end{array}$ & $\begin{array}{l}\text { TIPO } 3 \\
\text { P\&D } \\
\text { racionalizado }\end{array}$ & $\begin{array}{l}\text { Laboratório } \\
\text { Internacional } \\
\text {-mente } \\
\text { integrado }\end{array}$ & $\begin{array}{l}\text { Unidade } \\
\text { Global de } \\
\text { Tecnologia }\end{array}$ \\
\hline & Função & $\begin{array}{l}\text { Desenvolvimen } \\
\text { to de produtos }\end{array}$ & $\begin{array}{l}\text { Desenvolvime } \\
\text { nto de ativos } \\
\text { tecnológicos }\end{array}$ & $\begin{array}{l}\text { Desenvolvi } \\
\text { mento de } \\
\text { ativos } \\
\text { tecnológicos }\end{array}$ & $\begin{array}{l}\text { Desenvolvi } \\
\text {-mento }\end{array}$ \\
\hline & Abrangência & Global & Global & Internacional & Regional \\
\hline & $\begin{array}{l}\text { Grau de } \\
\text { autonomia }\end{array}$ & Alto & Médio/alto & Médio/alto & Médio/alto \\
\hline $\begin{array}{l}\text { Laboratório } \\
\text { autônomo }\end{array}$ & Nome & $\begin{array}{l}\text { LII } \\
\text { Laboratório } \\
\text { Internacionalme } \\
\text { nte integrado }\end{array}$ & $\begin{array}{l}\text { TIPO 4 } \\
\text { P\&D } \\
\text { procurando } \\
\text { ativo } \\
\text { estratégico }\end{array}$ & - & $\begin{array}{l}\text { Unidade de } \\
\text { Tecnologia } \\
\text { corporativa }\end{array}$ \\
\hline
\end{tabular}




\begin{tabular}{|l|l|l|l|l|l|}
\hline & Função & $\begin{array}{l}\text { Pesquisa } \\
\text { pré-competitiva }\end{array}$ & $\begin{array}{l}\text { Pesquisa } \\
\text { pré- } \\
\text { competitiva }\end{array}$ & - & $\begin{array}{l}\text { Pesquisa } \\
\text { pré- } \\
\text { competitiv } \\
\text { a }\end{array}$ \\
\cline { 2 - 6 } & Abrangência & Global & Global & - & Global \\
\cline { 2 - 5 } & $\begin{array}{l}\text { Grau de } \\
\text { autonomia }\end{array}$ & Muito Alto & Alto & - & Alto \\
\hline
\end{tabular}

Por fim, vale lembrar que Pearce (1999) defende que a "posição da P\&D descentralizada das multinacionais tem passado por uma transformação crucial, deixando o status de ofertante de suporte técnico para operações locais de pequena escala e se tornando ‘jogador' com papel central em estratégias globais relacionadas tanto ao atual mercado competitivo, quanto à evolução tecnológica" (p.39). O mesmo autor também diz que “sobreviver na contemporânea competição globalizada requer a incorporação de altos níveis de receptividade do mercado, de modo que o estoque de conhecimento da firma seja aplicado comercialmente, e também um compromisso com a necessidade de revitalizar e gerar novamente a core technology como ativo competitivo" (p.39).

\section{2- INDICADORES DE CIÊNCIA E TECNOLOGIA}

De acordo com o manual da Fapesp intitulado "Indicadores de ciência, tecnologia e inovação em São Paulo" de 2004: indicadores de C\&T são alguns indicadores de insumos como recursos humanos, financeiros e infra-estrutura para pesquisa, alguns indicadores de resultados como patentes e dados sobre produção científica e um conjunto de indicadores de impacto. Os mais tradicionalmente usados são os indicadores de dispêndio, e por isso, são também os mais consultados, os principais exemplos desses são valores públicos ou privados investidos diretamente em C\&T. 
Além disso, é primordial que os indicadores, para serem considerados com tal, apresentem duas características intrínsecas. A primeira delas é a temporalidade: os indicadores devem indicar tendências, rompimento de paradigmas, desta forma, é imprescindível uma cadeia histórica. A segunda das características inerentes é a comparabilidade: para tanto, os números obtidos devem ser tratados seguindo-se metodologias já consolidadas internacionalmente para poderem ser comparados a indicadores de outros países ou setores.

Em palestra apresentada na 58 Reunião Anual da SBPC (Sociedade Brasileira para o Progresso da Ciência), a sócio-fundadora do CGEE (Centro de Gestão e Estudos Estratégicos), Lúcia Carvalho Pinto de Melo, ressaltou que existem três razões pelas quais é fundamental medir C\&T:

1- Entender qual é o atual panorama do conhecimento de um país;

2- Desvendar quais são as tendências e em que o governo deve investir em termos de políticas públicas para atender tais demandas;

3- Saber quais são as áreas estratégicas com potencial de crescimento onde se deve investir que deixe a nação em uma vantagem competitiva.

Aqui, fazendo-se uso dos dois indicadores propostos - patentes e dados bibliométricos - pretende-se conseguir mensurar e analisar tanto a Ciência quanto a Tecnologia, pois a primeira é vista através dos papers publicados e a segunda por meio dos registros das patentes nos órgãos competentes. 


\subsection{1- REGISTRO DE PATENTES}

Durante anos, os registros de patentes vêm sendo usados como indicadores de desenvolvimento. A inovação necessariamente precisa ser registrada para garantir a proteção da propriedade intelectual, desta forma não há maneira melhor de medir o grau de interesse pelo desenvolvimento de novas tecnologias de empresas e paises do que a quantificação do número de patentes pertencente ao elemento estudado. Joseph Schumpeter (1982), nas primeiras décadas do século XX, demonstrou em suas publicações a importância do processo de inovação para o crescimento do produto.

O número de patentes registradas por uma empresa em diferentes paises onde atua reflete também a importância que dá a cada mercado e como aloca seus recursos de pesquisa. Se uma subsidiaria possui mais inovações desenvolvidas que outra, possivelmente isso é reflexo de um maior investimento e incentivo a atividades de inovação do grupo àquele local.

Hoje em dia, qualquer descoberta inovativa, seja ela de empresas ou pesquisadores independentes, é logo registrada nos órgãos que protegem os direitos dos inventores, essa prática se tornou muito mais comum do que era antigamente. Registrar a patente de uma nova tecnologia obriga o inventor a publicar todos os passos para a aquisição do novo processo ou produto, somente desta forma a inovação pode ser registrada. Entretanto não é estritamente necessário que a novidade seja colocada em prática, apenas um plano detalhado de como isso seria feito garante a autenticidade do registro. Desta forma é possível que não se encontre todos os produtos com patentes registradas disponíveis no mercado, alguns podem estar esperando novas oportunidades para serem lançados ou mesmo ainda não tiveram investimentos da empresa para transformar a inovação em um 
produto, já que entre a descoberta de algo novo e sua adaptação para o mercado consumidor vai tempo e gasta-se muito dinheiro.

O registro de patentes se tornou também um dos principais indicador utilizado quando se deseja medir as condições de uma empresa frente às inovações desenvolvidas pelo mercado. Archibugi e Pianta (1996) sistematizaram algumas vantagens estatísticas do uso de patetes como indicadores de Ciência e Tecnologia (C\&T): Alta comparabilidade atemporal, já que patentes têm sido registradas a mais de um século; possibilidade de comparações internacionais; alta comparabilidade no nível de gastos nacionais.

De acordo com o Manual da Organização para Cooperação Econômica e Desenvolvimento (1994), a ligação entre os departamentos de Pesquisa de Desenvolvimento das empresas e as patentes criadas são o grande incentivo para o uso dos registros como indicador de C\&T. Alem disso, o manual destaca o fato de patentes serem usadas em praticamente todos os ramos da tecnologia e serem documentos detalhados que possibilitam analises econômicas embasadas.

A literatura tem discutido o valor estatístico das patentes desde a década de 80 : Pavitt (1988) foi o precursor e até hoje um dos mais aceitos; em seu trabalho com Patel (1995), destaca-se, aquilo que talvez é o grande limitante do uso dos registros como indicador C\&T: Softwares não são patenteados e sim protegidos por copyright, fora isso, muitas qualidades são atribuídas ao uso de patentes.

Outro ponto positivo da mensuração da inovação por intermédio dos registros de patentes defendido por Keith Pavitt diz respeito ao impacto das patentes na produtividade das universidades. As patentes têm sido um indicador importante, embora não suficiente, na medição das atividades que contribuem para a mudança técnica. 
Existem diversas publicações que regulamentam o uso de patentes como indicador da inovação, o mais aceito e de maior cobertura é o Manual de Oslo, a partir dele vários outros foram desenvolvidos para regionalizar o que é proposto. No Brasil e mais precisamente no estado de São Paulo, destaca-se o manual de indicadores da FAPESP.

Em geral, os artigos sobre o tema descrevem o Brasil como um destino pouco adotado pelas multinacionais para alocar seus dólares destinados a P\&D. Parte da explicação para isso vem do fato de até então o Brasil não ser considerado referência mundial em nenhuma área especifica do conhecimento.

Galina (2001) confirma a pouca atuação do Brasil em um estudo envolvendo empresas do setor de telecomunicações. Segundo a autora, o principal papel dos centros de Pesquisa e Desenvolvimento instalados nas subsidiarias brasileiras das empresas estudadas é a adaptação das inovações descobertas em outros paises às condições peculiares do mercado nacional.

Por outro lado, Thomson \& Nelson (1997) apontam três motivações para a obtenção de patentes em países estrangeiros:

1) Ela viabiliza a extração de renda derivada do licenciamento de tecnologia de firmas nacionais;

2) Uma garantia para operar localmente e para vender produtos nos mercados nacionais;

3) Um mecanismo para assegurar mercados para exportações.

A principal base de dados que foi utilizada para os estudos que serviram de suporte para essa dissertação são provenientes do The European Patent Office (EPO). 


\subsubsection{1- EUROPEAN PATENT OFFICE}

O European Patent Office é uma organização intergovernamental que foi formada em 7 de outubro de 1977 com base na convenção européia da patente que havia sido assinada em Munich no ano de 1973. A entidade tem dois, hoje, corpos: o EPO propriamente dito e o conselho administrativo, que é responsável pela supervisão das atividades do escritório.

Mais de 20 estados encontraram-se na conferência diplomática de Munich em 1973 para discutir a introdução de um procedimento europeu comum para concessão de patentes. A conferência acabou com assinatura de 16 participantes, no entanto, o EPO só concedeu suas primeiras patentes em 1980.

Segundo o próprio site da instituição, a missão do EPO é dar suporte à inovação, à competitividade e ao crescimento econômico para o benefício dos cidadãos de Europa. Desta forma o EPO pretende ainda: ajustar os padrões de proteção de patentes; manter sua posição como um jogador global no mundo das patentes; ser um dos principais fornecedores do mundo no que tange a informação técnica e ajudar a promover uma sociedade baseada no conhecimento.

A organização tem atualmente 32 estados membros e outros 5 em processo de adesão à entidade. Os componentes do EPO são Áustria, Bélgica, Bulgária, Suíça, Chipre, República Tcheca, Alemanha, Dinamarca, Estónia, Espanha, Finlândia, França, Reino Unido, Grécia, Hungria, Irlanda, Islândia, Itália, Liechtenstein, Lituânia, Luxemburgo, Mônaco, Malta, Países Baixos, Polônia, Portugal, Romênia, Suécia, Eslovênia, Eslováquia e Turquia. 
Em suma, o EPO é responsável pelo fornecimento de procedimentos uniformes a serem aplicados tanto para inventores individuais como para companhias que procuram a proteção da patente de suas invenções em até 37 países europeus.

\subsection{2- DADOS BIBLIOMÉTRICOS}

O outro indicador utilizado neste estudo para medir o grau de integração entre matrizes e subsidiárias se refere aos dados bibliométricos, ou seja, a quantidade de artigos científicos publicados por essas empresas em periódicos de destaque.

As primeiras tentativas para reunir citações e facilitar o acesso às informações surgiram ainda no século 19, tais como as citações de Shepard (1873). Depois disso, tem destaque os esforços do instituto Eugene Garfield, que em 1960, introduziu o primeiro índice da citação para os artigos científicos publicados nos jornais acadêmicos. Atualmente, com a disseminação da tecnologia, encontrar informações relevantes para uma pesquisa ficou bem mais prático, existem muitas fontes de dados, como o popular Scholar do Google.

Segundo Galina (2001), hoje em dia, os dados bibliométricos são usados como indicador do posicionamento de um país em termos de publicações científicas relevantes. E quando diferentes regiões devem ser comparadas, a coleta de dados é feita em diferentes bases, o que possibilita abranger um número maior de periódicos significativos e generalizar as áreas temáticas.

Para este estudo os dados bibliométricos são provenientes do SCI (Science Citation Index), editado pelo ISI (Institute for Scientific Information).As consultas aos dados bibliométricos do ISI podem ser feitas através da base de dados disponível na internet. O 
SCI é um banco de dados que contempla diversas áreas do conhecimento e conta com mais de 5000 periódicos relacionados a ciências humanas, meio ambiente, tecnologia, medicina etc. Além desses atributos que já merecem ser considerados, o SCI é a base de dados que compreende o número mais significativo de publicações relativas à América Latina. Entretanto em 1997, as publicações desta região representaram apenas 2,3\% do total das publicações registradas no SCI (RICYT, 1999).

\subsubsection{1- SCIENCE CITATION INDEX}

O Science Citation Index fornece acesso a informações bibliográficas atuais e retrospectivas, a sumários de autores e a referências de citações encontradas em 6.400 dos principais periódicos e jornais técnicos do mundo, que cobrem mais de 100 disciplinas.

A ferramenta de acesso à base de dados permite que os pesquisadores conduzam suas buscas de diferentes formas, primando sempre pelo detalhamento, e que as informações requeridas sejam encontradas, quebrando assim, as barreiras geográficas e disciplinares.

Estão disponíveis neste banco de dados aproximadamente 1.3 milhão de artigos e cerca de 35 milhões de citações. Dentre essas informações, está disponível o ISI (Institute for Scientific Information).

O ISI é uma plataforma integrada e versátil da pesquisa que entrega ao usuário acesso fácil a informações acadêmicas diversificadas nas áreas de ciências naturais, ciências sociais, artes e humanidades, assim como, ferramentas de análise que realçam estes resultados. O ISI, diferentemente da maioria das ferramentas de busca disponíveis na 
internet, possibilita que o pesquisador filtre diversos índices de sua pesquisa e alcance resultados mais diretos e relevantes.

“A missão básica do Institute for Scientific Information, como uma companhia publicadora de base de dados, é oferecer uma cobertura abrangente da mais importante e influente pesquisa em todo o mundo" (TESTA, 1998 p.233).

Destacam-se nessa base sua ampla abrangência de periódicos em nível mundial, a sua estrutura bem definida e qualidade padrão. Sendo assim, uma boa opção para avaliar a produção científica em âmbito internacional, além de ter fácil acesso via Internet. Outra característica fundamental da base é citar todos os autores e co-autores e seus respectivos endereços, desse modo, é possível analisar as publicações entre empresas, centros de pesquisa e países. Entretanto, fundamentalmente, trata-se de uma base concebida e desenvolvida para a identificação e recuperação de informação sobre a literatura especializada e cientistas atuantes nas diferentes disciplinas, não se revelando, portanto, totalmente adequada para a produção de estatísticas sobre a produção científica, apesar de amplamente empregada com essa finalidade (ADAM apud FAPESP 2004). Ainda, argumenta-se que há certo viés nas bases mantidas pelo ISI em benefício dos periódicos e publicações em língua inglesa, favorecendo principalmente às de origem norte-americana, ficando a ciência européia, em geral, e a dos países em desenvolvimento sub-representadas (GARCIA; TARGINO, 2000). 


\section{3- PAISES EM DESENVOLVIMENTO E A DISPUTA PELO IDE}

Outro ponto imprescindível que deve ser tratado diz respeito às políticas nacionais de atração e manutenção dos investimentos estrangeiros dentro do país. A disputa pelo IDE, mundo afora, vem se tornando cada vez mais acirrada.

Não é por outra razão, que se verifica a iniciativa de mais de 100 países se mobilizarem e constituírem organismos voltados para as atividades de atração de investimentos e a promoção de oportunidades, mais da metade dessas ações, implementados a partir de 1994.

Aquele país que desejar entrar nessa disputa pelos recursos destinados a P\&D das multinacionais e melhorar sua posição na cadeia do desenvolvimento tem que aprimorar suas normas que regularizam as políticas de competitividade.

Quando o país se volta para o aumento e a melhoria da competitividade, automaticamente, os mecanismos de política industrial, incentivos às pesquisas e às exportações se desenvolvem e as desvantagens estruturais até então existentes são reduzidas, como por exemplo, as áreas de logística e tributação evoluem em ritmo acelerado.

Cientes da importância do recebimento de investimentos estrangeiros, muitos países criaram órgão responsabilizados pela atração desse dinheiro. A WAIPA - Associação Internacional das Agências de Promoção de Investimentos - reúne 167 agências de âmbito nacional, em 142 países, o que demonstra a acirrada competição pelos investimentos produtivos no mundo. 
Tabela 4 - 20 maiores recebedores de ide entre os países em desenvolvimento

(US\$ milhões)

\begin{tabular}{|c|c|c|c|c|c|c|c|c|}
\hline 2000 & US\$ & $\%$ & 2001 & US\$ & $\%$ & 2002 & US\$ & $\%$ \\
\hline 1 Hong Kong & 61939 & 4.4 & 1) China & 46846 & 5.7 & 1 China & 52700 & 8.1 \\
\hline 2 China & 40772 & 2.9 & 2 México & 25334 & 3.1 & 2 Brasil & 16566 & 2.5 \\
\hline 3 Brasil & 32779 & 2.4 & 3 Hong Kong & 23775 & 2.9 & 3 Hong Kong & 13718 & 2.1 \\
\hline 4 México & 15484 & 1.1 & \begin{tabular}{l|l|} 
Brasil \\
\end{tabular} & 22457 & 2.7 & 4 México & 13627 & 2.1 \\
\hline 5 Cingapura & 12464 & 0.9 & 5 Cingapura & 10949 & 1.3 & $\begin{array}{ll}5 \text { Rep. Checa } \\
\end{array}$ & 9319 & 1.4 \\
\hline \begin{tabular}{l|l|}
6 & Argentina \\
\end{tabular} & 11657 & 0.8 & 6|África do Sul & 6789 & 0.8 & \begin{tabular}{l|l|}
6 & Cingapura \\
\end{tabular} & 7665 & 1.2 \\
\hline 7 Polônia & 9341 & 0.7 & 7 Polônia & 5713 & 0.7 & 7 Polônia & 4119 & 0.6 \\
\hline 8 Coréia do Sul & 9283 & 0.7 & 8 Rep. Checa & 5639 & 0.7 & 8 Eslováquia & 4012 & 0.6 \\
\hline \begin{tabular}{l|l} 
Rep. Checa \\
\end{tabular} & 4984 & 0.4 & 9 Chile & 4477 & 0.5 & 9 Índia & 3449 & 0.5 \\
\hline \begin{tabular}{l|l|}
10 & Taiwan \\
\end{tabular} & 4928 & 0.4 & \begin{tabular}{l|l|}
10 & Taiwan \\
\end{tabular} & 4109 & 0.5 & 10|Malásia & 3203 & 0.5 \\
\hline 11|Venezuela & 4465 & 0.3 & 11|Tailândia & 3813 & 0.5 & 11|Kazaquistão & 2561 & 0.4 \\
\hline 12 Malásia & 3788 & 0.3 & 12 Coréia do Sul & 3528 & 0.4 & 12 Rússia & 2421 & 0.4 \\
\hline 13 Chile & 3639 & 0.3 & 13Venezuela & 3448 & 0.4 & 13 Colômbia & 2034 & 0.3 \\
\hline 14|Tailândia & 3350 & 0.2 & 14 Índia & 3403 & 0.4 & 14 Coréia do Sul & 1972 & 0.3 \\
\hline 15 Rússia & 2714 & 0.2 & $\begin{array}{l}15 \text { Turquia } \\
\end{array}$ & 3266 & 0.4 & 15 Chile & 1603 & 0.2 \\
\hline 16|índia & 2319 & 0.2 & 16 Argentina & 3206 & 0.3 & 16|Peru & 1462 & 0.2 \\
\hline 17 Colômbia & 2237 & 0.2 & 17|Kazaquistão & 2823 & 0.3 & 17| Taiwan & 1445 & 0.2 \\
\hline 18|Filipinas & 1345 & 0.1 & 18 Colômbia & 2521 & 0.3 & 18 Angola & 1312 & 0.2 \\
\hline 19|Vietnã & 1289 & 0.1 & 19Rússia & 2469 & 0.3 & 19|Nigéria & 1281 & 0.2 \\
\hline 20 Kazaquistão & 1283 & 0.1 & \begin{tabular}{l|l|}
20 & Angola \\
\end{tabular} & 2146 & 0.3 & 20 Vietnã & 1200 & 0.2 \\
\hline & & & & & & & & \\
\hline TOTAL & 168121 & 16.5 & TOTAL & 186711 & 22.7 & TOTAL & 145669 & 22.4 \\
\hline
\end{tabular}

Fonte: UNCTAD/WIR 2003 e SOBEET.

Em estudo divulgado no ano de 2004, a UNCTAD aborda as ações tomadas por diversos governos nacionais de atraírem centros de P\&D para seus países, com objetivo de desenvolverem centros locais de alta tecnologia, como parques tecnológicos, por exemplo. A iniciativa e a consolidação destes parques pode cumprir um papel importante na atração tanto de companhias nacionais quanto estrangeiras e seus budgets destinados às atividades de $\mathrm{P} \& \mathrm{D}$, destacam-se aqueles parques localizados próximos a universidades e institutos de pesquisa (Reddy, 2000). 
Dentre todos os receptores de investimentos de multinacionais, há um grupo que merece destaque, os especialistas o chamam de BRIC. Esse grupo compreende Brasil, Rússia, Índia e China e como pode ser observado seu nome vem das iniciais dos nomes de seus membros.

O intuito desse estudo sempre foi analisar esses quatro paises que são hoje vitrine no que diz respeito a países em desenvolvimento que recebem IDE, no entanto, havia-se sempre o questionamento da situação Rússia quando comparada aos outros integrantes do BRIC. Para tentar sanar essa dúvida um levantamento piloto foi realizado em que foram coletados numero de patentes e dados bibliométricos da Rússia nos períodos em que esse trabalho se propôs a analisar. Como suposto, não foram encontrados dados relativos à Rússia e para evitar qualquer viés o país foi desconsiderado nessa dissertação.

\subsection{1- BRASIL}

O Brasil tem, atualmente, cerca de 190 milhões habitantes em seus 26 estados federativos, a moeda utilizada nacionalmente é o Real e as principais os principais produtos exportados por esse país extremamente diversificado são oriundos do agronegócio e da extração, de produções de mão-de-obra intensa (calçados e têxteis) e mais recentemente de alguns setores mais sofisticados, destacando-se aviões e submarinos.

No quadro nacional, a estabilização da economia, o fim dos monopólios estatais, o aprofundamento da abertura econômica e a consolidação das reformas foram fatores decisivos para o restabelecimento do clima de confiança dos investidores nas instituições, com isso o País pôde bater sucessivos recordes de atração de capital externo. 
De acordo com o Ministério do Planejamento, o programa de privatização foi decisivo para o aumento desses investimentos. Dos quase US\$ 90 bilhões que entraram no país entre 1995 e 1999, 26\% foram utilizados na compra de empresas estatais. Em 2000, a situação se estabilizou e outras formas de investimento se consolidaram, dos investimentos ingressantes registrados, $15 \%$ tinham o objetivo de comprar ações de empresas brasileiras.

A mesma fonte afirma que de uma média anual de US\$1,5 bilhão entre 1980 e 1994, os investimentos estrangeiros saltaram para US\$ 10 bilhões em 1996, US\$ 19 bilhões em 1997, US\$ 29 bilhões em 1998 e US\$ 30 bilhões em 1999.

O gráfico a seguir demonstra a evolução do ingresso de recursos no País:

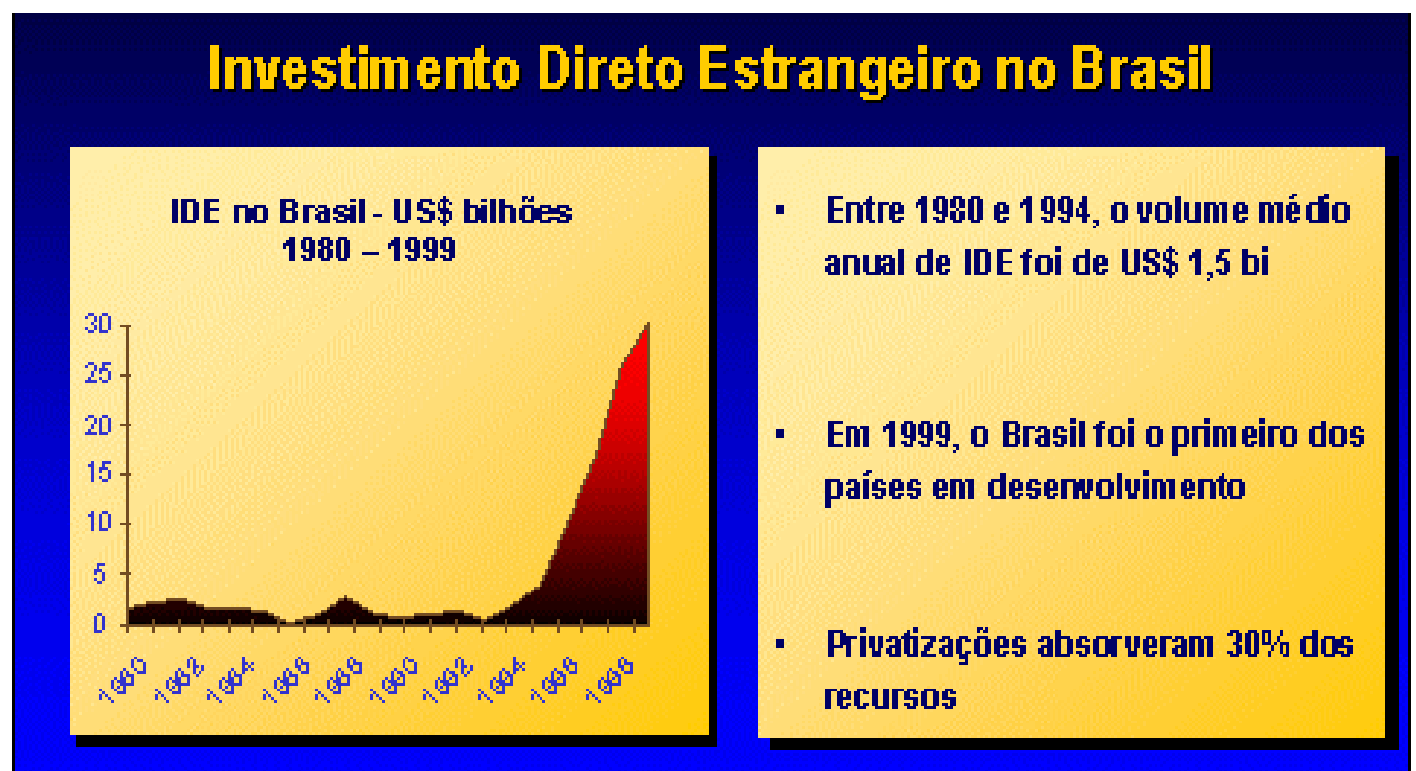

Gráfico 1- Fluxo de IDE no Brasil

Fonte: INVESTE BRASIL

O Brasil tem um forte histórico como receptor de Investimentos Diretos Estrangeiros (IDE). Em 2000, a entrada de IDE para o País atingiu o recorde de US\$ 32,8 bilhões, atraídos, principalmente, pelo ambiente macroeconômico estável, e pelas políticas 
de desregulamentação e de privatização. Contudo, esse fluxo não se manteve estável, reduzindo-se veementemente em função de agitações do cenário internacional e de instabilidades causadas pela transição política nacional, em 2002.

O Brasil, na busca de uma maior inserção internacional, busca desenvolver um ambiente favorável para atrair cada vez mais fatias maiores desses investimentos. A adoção de mecanismos inovadores, como as Parcerias Público Privadas (PPP), constitui exemplo da motivação do Governo Federal em possibilitar a realização de investimentos no País, principalmente na área de infra-estrutura.

Dentre as principais políticas publicas adotas pelo Brasil para a incentivar os investidores está a REDE BRASILEIRA DE PROMOÇÃO DE INVESTIMENTOS INVESTE BRASIL, uma sociedade civil sem fins lucrativos, constituída em cotas por representantes de setores da iniciativa privada. A instituição começou a funcionar em janeiro de 2001, como um organismo especializado na atração de investimentos diretos internacionais e na promoção do País entre os investidores nacionais e estrangeiros.

\subsection{2- CHINA}

Com uma população de mais de 1,294 bilhões de habitantes, a China é o país mais populoso do mundo. A moeda corrente utilizada é o Yuan, hoje extremamente desvalorizado frente ao Dólar. As principais atividades econômicas da China são: produção têxtil, principalmente algodão, materiais de construção com destaque para a produção de cimento e a siderúrgica (World Development Indicators 2002).

A China é, sem sombra de dúvidas, o país mais comentado e estudado atualmente no que diz respeito ao processo de internacionalização de $\mathrm{P} \& \mathrm{D}$, esse destaque deve-se tanto 
a grande importância que o país passou a ter no últimos anos para a economia mundial, quanto pela superação das dificuldades impostas pela recente história comunista chinesa.

Os resultados das políticas chinesas são um grande exemplo da capacidade que um Estado empenhado tem de se mobilizar e unir forças para promover e desenvolver um ambiente com capacidades tecnológicas apuradas. Venkitaramanan (2000) retrata uma China que usa inteligentemente sua enorme capacidade de atrair IDE para ampliar seu acesso a tecnologias que antes não eram necessárias para seu estado econômico, para tanto a China negocia investimentos em P\&D com os interessados em se instalarem no país como contrapartida ao acesso a seu gigantesco mercado.

Políticas de comércio, de compras governamentais e de tecnologia são coordenadas com o sistema de aprovação de investimento externo de modo a desenvolver as capacidades locais. Ao mesmo tempo, o país investe fortemente na formação de recursos humanos qualificados, tanto no país como no exterior (VENKITARAMANAN, 2000).

A respeito das políticas de arrasto de IDE, o governo chinês mostra-se a par da importância das empresas multinacionais para o desenvolvimento industrial do país. Dentre as ações planejadas para que tenha êxito nesse processo estão: a melhora de suas políticas de atração de investimentos, o aperfeiçoamento de suas leis que regulamentam a instalação dessas empresas, a implementação de uma nova prática de investimentos com fusões e aquisições, o agenciamento da distribuição do investimento que vem de empresas estrangeiras dando destaque para as regiões oeste e central (menos desenvolvidas) etc.

As ações de desenvolvimento regional consistem no direcionamento de investimentos estrangeiros para as regiões menos industrializadas do país, com incentivos do governo e crédito para a instalação da infra-estrutura necessária. O governo chinês ainda desenvolveu políticas com intuito de cobrar baixos impostos de empresas estrangeiras, 
principalmente daquelas que aceitam se instalarem em regiões que estão nos planos de desenvolvimento regional criados pelo governo.

Destacam-se as Zonas de Desenvolvimento Econômico e Tecnológico (ETDZs) como uma importante medida do governo chinês para seu desenvolvimento econômico, e também para a atração de empresas de grande porte e investimentos estrangeiros para o país. As ETDZs foram criadas no início de 1984, em cidades costeiras com objetivo de iniciar abertura econômica da China, hoje existem cerca de 55 ETDZs no país. Essas zonas são usadas para a atração de dinheiro, desenvolvimento tecnológico e aumento das exportações.

Estatísticas do governo chinês fornecidas por seu ministério de C\&T, o MOST Ministry of Science and Technology mostram que já há mais de 200 empresas multinacionais investindo nas regiões incentivadas pelas políticas locais, esses planos industriais já totalizaram um numero absoluto de mais de 400 projetos em andamento ou prestes a começar.

Graças a ações planejadas como essas, a China é, hoje, o grande receptor de IDE, tendo recebido na última década o acumulado de US\$ 415 bilhões em investimentos diretos. Isso tudo sem levar em conta os investimentos destinados a Hong Kong - que são levantados independentemente. Considerando-se a antiga colônia inglesa na Ásia, o acumulado de IDE para o período sobe para o valor de US\$ 550 bilhões (US\$ 134,7 bilhões provenientes de Hong Kong).

De acordo com declarações do governo da China, a política industrial que adotaram se tornou um importante utensílio para o controle do investimento direto estrangeiro, principalmente, no que se refere a direcionar esses investimentos para indústrias ou setores específicos que necessitam de mais incentivos (target industry). 
Em abril de 2002, foi lançado na China um projeto que busca dar incentivos à entrada de Investimento Direto Estrangeiro para setores específicos da economia, como a agricultura, o desenvolvimento de recursos, de infra-estrutura e pesquisas para produtos de alta tecnologia. O "Catalogue for the Guidance of Foreign Investment Industries" também tem como seu escopo restringir e até mesmo proibir a entrada massiva de capital estrangeiro em setores que são considerados estratégicos para a segurança da economia local e do governo - telecomunicações e automóveis, por exemplo.

\subsection{3- ÍNDIA}

A República da Índia tem uma população de mais de 1,1 bilhão de pessoas e é tida como a maior democracia do mundo, apesar de muito diferentes (23 línguas são reconhecidas na Índia) os indianos utilizam uma única moeda, a Rúpia Indiana. O grande destaque da economia indiana internacionalmente é a produção de softwares, o país é atualmente o maior produtor mundial.

Assim com a China, a Índia também é um exemplo de país em desenvolvimento fortemente empenhado em atrair atividades corporativas mais avançadas para seu território. Segundo Basu (2003), em fevereiro de 2003 havia uma centena de centros de P\&D de multinacionais na Índia, sendo mais de setenta criados nos últimos cinco anos.

Mesmo sendo a maior parte desses centros voltada para atividades de desenvolvimento mais simples, como a adaptação de produtos às condições locais e o suporte à produção de plantas instaladas no país, há também centros de $\mathrm{P} \& \mathrm{D}$ globais que são responsáveis por atividades extremamente sofisticadas. 
Um exemplo dessa situação é o centro de P\&D da GE em Bangalore, segundo a própria empresa, esse é o maior que a ela mantém fora dos EUA, dando emprego para cerca de 1.600 pessoas, entre os quais mais de 1.000 são técnicos especializados $(31 \%$ destes com doutorado e 44\% com mestrado). O centro da GE na Índia é responsável por pesquisa fundamental em áreas extremamente revolucionárias como nanotecnologia, energia baseada em hidrogênio, fotônica e propulsão avançada.

Dentre as medidas tomadas pela Índia para conquistar os dólares de pesquisa disputados por vários paises estão:

A abertura de canais de relacionamento com os departamentos de P\&D das empresas para troca de informações e monitoramento de suas estratégias;

O desenvolvimento de políticas públicas para melhorar qualitativamente o esforço de atração de investimentos, por meio do acréscimo de dimensão específica voltada para a inovação e a competitividade;

- $\quad$ A promoção de ações pontuais e genéricas de atração de investimento externo em P\&D;

Uma pesquisa realizada pelo Economist Intelligence Unit (2004), entrevistou 104 executivos de grandes empresas mundiais e revelou que, dentre os Paises em desenvolvimento, o segundo país listado entre os principais destinos de investimentos estrangeiros em P\&D para os próximos três anos (terceiro na classificação geral, quanto contabilizados também os países desenvolvidos) foi a Índia, ficando atrás apenas do fenômeno China. 
A Índia tem mais de 250 universidades, 1.500 instituições de pesquisa e 10.428 institutos de educação superior, esses institutos formam 200.000 engenheiros, 300.000 graduados técnicos e 5.000 doutores por ano (Basu, 2003). Fica claro que os exemplos de Índia e China, mais uma vez, mostram que a disponibilidade de técnicos altamente qualificados - e a custo baixo - tem sido um fator decisivo para a concretização de investimentos em P\&D por parte de empresas estrangeiras. 


\section{5- METODOLOGIA ADOTADA}

A metodologia é o estudo das formas de se realizar uma pesquisa científica. Desta forma, o método representa o procedimento munido de instrumentos básicos e implica na utilização da reflexão e da experimentação para alcançar os objetivos de uma pesquisa. Ao se planejar uma pesquisa científica é preciso, sempre, examinar seus objetivos e determinar o método mais apropriado para atingi-los.

Toda a elaboração da metodologia desta dissertação foi feita com foco no fato deste trabalho fazer parte de um projeto maior da FAPESP (Projeto Políticas Públicas, REF. PROCESSO: 03/06388-9) que visa, principalmente, contribuir para a formulação de políticas de atração e desenvolvimento de atividades tecnológicas em filiais brasileiras de multinacionais.

Desta forma, todo o trabalho de coleta e tratamento dos dados utilizados nessa dissertação também fazem parte de uma das frentes deste projeto da FAPESP, que utiliza, alem das informações disponibilizadas nas bases do EPO e do SCI, dados extraídos do USPTO (United States Patent and Trademark Office) e do INPI (Instituto Nacional de Propriedade Intelectual).

O trabalho aqui realizado pode ser dividido em duas partes distintas, assim como a metodologia utilizada para a sua realização. A primeira delas terá uma abordagem mais tradicional, baseando-se no paradigma positivista e fazendo uso de dados quantitativos. A segunda etapa do trabalho será caracterizada por uma pesquisa exploratória de caráter qualitativo. 
JICK (1979) chama a combinação de métodos quantitativos e qualitativos de "triangulação". Essa estratégia é defendida por diversos pesquisadores, dentre eles DUFFY (1987, p.131), que indica como benefícios do emprego conjunto de métodos qualitativos e quantitativos:

1) Possibilidade de congregar controle dos vieses (pelos métodos quantitativos) com compreensão da perspectiva dos agentes envolvidos no fenômeno (pelos métodos qualitativos);

2) Possibilidade de congregar identificação de variáveis específicas (pelos métodos quantitativos) com uma visão global do fenômeno (pelos métodos qualitativos);

3) Possibilidade de completar um conjunto de fatos e causas associados ao emprego de metodologia quantitativa com uma visão da natureza dinâmica da realidade;

4) Possibilidade de enriquecer constatações obtidas sob condições controladas com dados obtidos dentro do contexto natural de sua ocorrência;

5) Possibilidade de reafirmar validade e confiabilidade das descobertas pelo emprego de técnicas diferenciadas.

A escolha de apenas um método quantitativo de pesquisa pode levar o pesquisador a formular questões somente para exercitá-lo, o que acaba transformando a pesquisa em um simples exemplo didático, talvez bom para a sala de aula, mas sem relevância para a ciência.

Silva (2004) conclui sobre o emprego de apenas dados quantitativos que é comum encontrar trabalhos que foram confinados pela análise estatística e acabaram incapazes de produzir conclusões relevantes. 
Cabe ressaltar a importância do levantamento bibliográfico para o bom andamento da pesquisa, de acordo com Gil (1999 p. 65) “a pesquisa bibliográfica é desenvolvida a partir de material já elaborado, constituído principalmente de livros e artigos científicos”.

Gil (2000) classifica as pesquisas em: pesquisas bibliográficas, pesquisas documentais, levantamentos, estudos de caso, estudos de campo e pesquisas experimentais. Neste caso, serão usados levantamento e estudo de caso, prioritariamente, sendo que a principal etapa do estudo será baseada em uma pesquisa qualitativa de caráter exploratório, na forma de estudo de casos.

Yin (2005, p.32) lembra que o estudo de caso "é uma investigação empírica que investiga um fenômeno contemporâneo dentro do seu contexto da vida real”.

Não importa qual a estratégia analítica específica seja escolhida, deve-se fazer de tudo para ter certeza de que a análise é de alta qualidade (YIN, 2005).

A análise e interpretação dos dados coletados, segundo Chizzotti (2005 p.164), “trata-se de classificar, categorizar, compilar os dados, descrevê-los, analisá-los e chegar às conclusões a respeito da hipótese aventada no início, seja para confirmá-la, seja para infirmá-la".

Há quatro princípios que fundamentam a boa ciência social:

a) A análise deve deixar claro que se baseou em todas as evidências;

b) Abranger todas as principais interpretações concorrentes;

c) Deve se dedicar aos aspectos mais significativos do estudo de caso;

d) O pesquisador deverá utilizar seu conhecimento prévio de especialista no estudo de caso. 


\section{1- ESTRUTURA DA PESQUISA}

Este trabalho possui o objetivo geral de realizar análises comparativas das empresas estrangeiras localizadas no Brasil em relação às mesmas localizadas na Índia e na China levando em consideração indicadores de C\&T que reflitam a internacionalização das atividades de P\&D nas subsidiarias dessas empresas. A partir desse foco, quatro objetivos mais específicos foram traçados e a forma como serão atingidos será exposta nesse capitulo.

O primeiro desses objetivos específicos se propõe comparar os indicadores de C\&T levantados nos dois períodos de análise, para tanto, serão usadas ferramentas estatísticas descritivas que possibilitam análises mais profundas. Pretende-se com esse objetivo, também, mapear os avanços que o Brasil teve em relação aos "concorrentes diretos" pelo IDE, mas principalmente obter subsídios para as tomadas de decisões que serão necessárias para os próximos objetivos específicos.

O alvo seguinte dessa dissertação está no caminho trilhado pelo conhecimento dentro de uma mesma subsidiária de EMN, será verificado por meio das bases de dados que foram detalhadas no referencial teórico se as áreas tecnológicas em que são publicados papers com autoria de funcionários das empresas são as mesmas em que essas companhias registram patentes nos países estudados. Desta forma espera-se descobrir se há coerência entre os investimentos em P\&D e os resultados práticos obtidos pelas empresas levantadas.

No ultimo objetivo específico desse estudo, o trabalho se torna menos quantitativo e mais qualitativo. Dentre as 298 empresas selecionadas para levantamento do numero de patentes e artigos publicados, o grupo de pesquisadores filiados ao estudo da FAPESP do qual essa dissertação faz parte selecionou 46 companhias para serem estudados mais 
detalhadamente.Estão sendo agendadas entrevistas com os responsáveis por P\&D das filiais brasileiras dessas empresas e uma das questões respondidas nas entrevistas diz respeito às políticas que as matrizes adotam para patenteamento a partir do Brasil. Cabe a essa dissertação analisar consistentemente as respostas obtidas.

\section{2- COLETA DE DADOS: MÉTODO E INSTRUMENTOS}

A primeira etapa do estudo será feita através de dois indicadores de ciência e tecnologia que servirão como referência para a formulação dos resultados, são esses indicadores: o número de patentes registradas pelas empresas em estudo e a quantidade de artigos acadêmicos publicados por autores ligados a essas mesmas empresas.

Para o levantamento de dados de patentes será utilizada a base do EPO (The European Patent Office) que indica e mensura as patentes de inovações registradas pelas empresas interessadas no mercado.

Para a obtenção dos dados bibliométricos, ou seja, referentes aos artigos publicados e indexados, será utilizada a base de dados multidisciplinar Science Citation Index Expanded (SCIE) do Institute of Scientific Information, Filadélfia, EUA. “A missão básica do Institute for Scientific Information (ISI), como uma companhia publicadora de bases de dados, é oferecer uma cobertura abrangente da mais importante e influente pesquisa em todo o mundo" (TESTA, 1998 p.233).

Os levantamentos explicitados serão feitos para os o Brasil e para os outros dois países em desenvolvimento que competem diretamente para recebimento de investimentos em P\&D: China e Índia. Os três países, juntamente com a Rússia, fazem parte do grupo denominado BRIC, graças as iniciais dos nomes de seus membros. 
As consultas às bases de dados de patentes, nas duas organizações escolhidas para esse trabalho - USPTO e EPO - podem ser feitas através das informações disponibilizadas na internet. Em ambas, as informações contemplarão os últimos dez anos, período em que, de acordo com o Ministério da Ciência e Tecnologia do Brasil, o país voltou a ser um destino de destaque de investimentos estrangeiros. Com a intenção de comparar os avanços nas políticas de atração e manutenção de IDE e seus reflexos, procurou-se comparar os cinco últimos anos da década passada (1996 a 2000) com os primeiros cinco anos desta década (2001 a 2005).

A base do EPO está sendo utilizada nessa pesquisa, pelo fato de conter informações do maior número de paises que uma única base de dados pode representar no mundo, toda a união européia faz uso das mesmas leis de patentes e os registros têm validade continental. Alem disso, os dados são bem mais detalhados do que os provenientes de outras bases, como por exemplo a brasileira, que é mantida pelo INPI (Instituto Nacional da Propriedade Intelectual). Essa qualidade das informações implica numa flexibilidade muito maior durante as pesquisas na base européia, o que significa que no EPO é possível fazer diferentes tipos de consultas e receber um conjunto de dados mais específicos.

O outro indicador escolhido para medir o envolvimento entre matrizes e subsidiárias brasileiras de EMNs refere a dados bibliométricos, ou seja, a quantidade de artigos científicos publicados em periódicos de destaque. Vale citar que, enquanto as patentes estão ligadas à pesquisa aplicada e desenvolvimento experimental (para posterior produção e comercialização do produto), as publicações científicas geralmente se referem à pesquisa básica. Dessa forma, com esses dois indicadores de resultados de C\&T, cobre-se todos os tipos de atividades realizadas em P\&D, o primeiro indicador cobre a Desenvolvimento, 
enquanto que os artigos publicados referem-se ao interesse que é dado à Pesquisa propriamente dita (OECD, 1994).

As consultas aos dados bibliométricos do ISI foram feitas também através da base de dados disponível na internet. O SCI é multidisciplinar e compreende cerca de 5300 periódicos relacionados a ciências humanas, meio ambiente, tecnologia e medicina. Além disso, ele é a base multidisciplinar que compreende o número mais significativo de publicações da América Latina. Em 1997, as publicações da região representaram 2,3\% do total das publicações registradas no SCI (RICYT, 1999).

Para qualquer um dos indicadores selecionados, os dados encontrados para a participação do Brasil serão confrontados com os dados dos outros países em estudo, para tanto será utilizada a ferramenta estatística da correlação.

Desta forma, é importante marcar que quando existem duas séries de dados que se movem juntamente através do tempo, a correlação é uma medida estatística muito apropriada para determinar a relação entre esses valores.

\section{3- PLANO DE TRABALHO}

Para a amostra foram selecionadas, em um primeiro momento, empresas que estão entre as 1000 maiores de acordo com o Jornal Valor Econômico de 2005 e que possuem capital estrangeiro ou misto. Foram adicionadas a esta lista outras empresas de destaque que mesmo não aparecendo no ranking estão notoriamente entre os maiores investidores em P\&D do mundo (investem mais de 100 milhões de libras em P\&D e estão presentes no Brasil), dados referentes ao "R\&D Scoreboard 2005", publicado pelo Department of Trade and Industry (DTI) do Reino Unido. 
A seleção dessas empresas foi feita com base em alguns critérios pré-estabelecidos, buscando garantir a representatividade da amostra. Assim, elaborou-se uma lista com 340 empresas pertencentes a 19 setores diferentes. Entretanto, após o levantamento de dados foi necessária uma nova seleção de empresas dentro das 340 já pesquisadas, isso porque para empresas de alguns setores específicos não foi encontrada uma quantidade significativa de dados, principalmente devido ao ramo de negócios em que opera e a natureza de suas atividades. Desse modo, foram re-selecionadas 182 empresas dos setores em que há maior possibilidade de desenvolvimento de atividade inovativa.

Desta forma, o trabalho tem seqüência com o levantamento dos dados relevantes. Todas as empresas restantes foram investigadas para a obtenção de informações relativas às patentes registradas em nome de suas filiais presentes no Brasil, na Índia e na China; o país de residência do inventor requisitante das patentes e o número de artigos científicos publicados por autores ligados as subsidiarias dessas empresas localizadas nos três países interessados.

Coletadas todas essas informações na base de dados de patentes - EPO - é o momento para a análise estatística das empresas e as variações apresentadas nos períodos estudados. A partir desse ponto o trabalho se torna mais detalhado e os objetivos específicos expostos anteriormente podem começam a ser atingidos.

Depois dessas etapas a situação atual do Brasil poderá ser mapeada frente aos paises concorrentes, e espera-se que se conhecendo bem onde e como o país está, seja mais fácil planejar onde se espera chegar com as políticas de incentivo adotadas.

Simultaneamente a essa fase, serão levantados os dados bibliométricas para os três paises estudados, essas informações obtidas serão tratadas e confrontadas com aquelas 
relativas às patentes. Essa informação é de extrema relevância para o trabalho como um todo e principalmente para o segundo objetivo especifico explicitado.

Nesse ponto, as áreas do conhecimento das patentes foram comparadas às dos artigos publicados por autores ligados às empresas em estudo. Pode ser, então, calculada a correlação entre essas séries de dados. O índice encontrado nunca pode ser maior do que 1 ou menor do que menos 1 .

No próximo estágio da dissertação foram elaborados relatórios comparativos entre os paises estudados, dando destaque para as empresas escolhidas pela equipe do projeto da FAPESP para as entrevistas estruturadas e cujas respostas servirão para analises presentes nesse estudo.

Por fim, os últimos esforços são destinados à redação dos relatórios finais da pesquisa. As conclusões serão expostas de maneira a dar ênfase à situação do Brasil frente à Índia e China e às políticas de pateteamento adotadas pela EMNs a partir do Brasil. 


\section{6 - RESULTADOS}

Nesta seção são apresentados os resultados obtidos nos levantamentos propostos para esse estudo e possibilitaram as conclusões que serão expostas a seguir. Assim como os objetivos específicos mostrados no capitulo três, o capitulo seis também será dividido em três partes ou seções, sendo cada uma delas diretamente ligadas a cada um dos objetivos.

A primeira das seções (seção 6.1) trata do objetivo especifico "Comparar a evolução dos indicadores - patentes e dados bibliométricos - das empresas selecionadas nos dois períodos de coleta dos dados em cada um dos países estudados”. Neste, serão mostrados de maneira geral os dados reunidos a partir das bases do EPO e do SCI e os resultados que mais se destacam serão ressaltados com gráficos e tabelas.

A seção com os resultados referentes ao objetivo especifico "Analisar se as empresas da amostra solicitam patentes nas mesmas áreas de conhecimento em que seus funcionários publicam artigos científicos nos três países estudados" trata da correlação entre as áreas de conhecimento das patentes publicadas em Brasil, Índia e China e os artigos indexados publicados com autores residentes nos mesmos paises.

Por fim, a ultima seção (seção 6.3) deste capítulo busca responder o seguinte objetivo: "Investigar quais são as políticas voltadas ao patenteamento de empresas multinacionais para as subsidiárias localizadas no Brasil”, para tanto foi desenvolvida uma formula para analise das respostas qualitativas dos questionários enviados para as empresa pesquisadas. 


\section{1 - A EVOLUÇÃO DA SITUAÇÃO DAS EMPRESAS SELECIONADAS NOS PERIODOS DE ESTUDO}

Após o levantamento e tratamento de todos os dados relacionados ao tema que esta dissertação se propunha a trabalhar, os resultados obtidos podem ser expostos de forma mais clara nas tabelas que são mostradas a seguir.

Para uma demonstração mais didática, os resultados de cada um dos indicadores serão expostos separadamente para que no próximo e último capitulo desta obra eles sejam discutidos dentro do contexto total que foi levantado nos capítulos anteriores.

Tabela 5 - Dados Totais EPO para as Empresas Estudadas

\begin{tabular}{|c|c|c|c|}
\hline \multirow[b]{2}{*}{ Empresa } & \multirow[b]{2}{*}{ Setor } & \multicolumn{2}{|c|}{ EPO } \\
\hline & & $1996-2000$ & $2001-2005$ \\
\hline Corn products & Alimentos & 4 & 1 \\
\hline Danone & Alimentos & 23 & 35 \\
\hline Yakult & Alimentos & 38 & 26 \\
\hline Ajinomoto & Alimentos & 231 & 389 \\
\hline Kraft Foods & Alimentos & 79 & 154 \\
\hline Nestlé & Alimentos & 478 & 475 \\
\hline Souza Cruz & Bebidas e Fumo & 0 & 0 \\
\hline McDonald's & Comércio & 1 & 4 \\
\hline Lojas Renner & Comércio & 0 & 0 \\
\hline Submarino & Comércio & 0 & 0 \\
\hline American Banknote & Comunicação e Gráfica & 0 & 0 \\
\hline Interprint & Comunicação e Gráfica & 2 & 0 \\
\hline Johnson \& Johnson & Cosmético e Higiene Pessoal & 941 & 1290 \\
\hline Colgate-Palmolive & Cosmético e Higiene Pessoal & 184 & 299 \\
\hline Avon & Cosmético e Higiene Pessoal & 23 & 66 \\
\hline Whirlpool & Eletroeletrônico & 129 & 224 \\
\hline Philips & Eletroeletrônico & 4633 & 8899 \\
\hline Electrolux & Eletroeletrônico & 258 & 362 \\
\hline Mabe & Eletroeletrônico & 0 & 4 \\
\hline Tractebel & Energia Elétrica & 1 & 0 \\
\hline Energias do Brasil & Energia Elétrica & 0 & 0 \\
\hline AES & Energia Elétrica & 2 & 6 \\
\hline Coelce & Energia Elétrica & 0 & 0 \\
\hline Pfizer & Farmacêutico & 602 & 996 \\
\hline Astrazeneca & Farmacêutico & 299 & 1001 \\
\hline Novartis & Farmacêutico & 643 & 855 \\
\hline
\end{tabular}




\begin{tabular}{|c|c|c|c|}
\hline Merck & Farmacêutico & 1237 & 1815 \\
\hline Eli Lilly & Farmacêutico & 723 & 543 \\
\hline GlaxoSmithKline & Farmacêutico & 25 & 164 \\
\hline Sanofi Aventis & Farmacêutico & 25 & 248 \\
\hline B. Braun & Farmacêutico & 49 & 41 \\
\hline Boehringer Ingelheim & Farmacêutico & 179 & 660 \\
\hline Bristol Myers & Farmacêutico & 367 & 678 \\
\hline Genzyme & Farmacêutico & 95 & 137 \\
\hline Roche & Farmacêutico & 962 & 1021 \\
\hline Saint Gobain & Materiais de Construção & 469 & 517 \\
\hline Holcim & Materiais de Construção & 11 & 23 \\
\hline Owens Illinois Brasil & Materiais de Construção & 46 & 28 \\
\hline ABB & Mecânica & 1682 & 1672 \\
\hline Schuler & Mecânica & 86 & 49 \\
\hline Voith Siemens & Mecânica & 4 & 9 \\
\hline ThyssenKrupp & Mecânica & 97 & 184 \\
\hline Atlas Schindler & Mecânica & 1 & \\
\hline Villares Metals & Metalurgia & 0 & 0 \\
\hline ESAB & Metalurgia & 29 & 25 \\
\hline Gonvarri & Metalurgia & 0 & 0 \\
\hline Alcoa & Metalurgia & 35 & 123 \\
\hline Alunorte & Metalurgia & 0 & 0 \\
\hline Procter \& Gamble & Multisetor & 3135 & 2714 \\
\hline \begin{tabular}{|l|} 
Unilever \\
\end{tabular} & Multisetor & 962 & 1249 \\
\hline International Paper & Papel e Celulose & 45 & 54 \\
\hline Aracruz Celulose & Papel e Celulose & 0 & 2 \\
\hline Bahia Pulp & Papel e Celulose & 0 & 0 \\
\hline Voith Paper & Papel e Celulose & 400 & 730 \\
\hline Faber Castell S.A. & Plástico e Borracha & 7 & 11 \\
\hline Dow & Químico e Petroquímica & 1468 & 1270 \\
\hline Rhodia & Químico e Petroquímica & 437 & 662 \\
\hline Roullier & Químico e Petroquímica & 0 & 0 \\
\hline $3 \mathrm{M}$ & Químico e Petroquímica & 63 & 2296 \\
\hline Du Pont & Químico e Petroquímica & 1757 & 1909 \\
\hline Shell & Químico e Petroquímica & 592 & 699 \\
\hline V\&M & Químico e Petroquímica & 10 & 33 \\
\hline Air Products Brasil Ltda & Químico e Petroquímica & 312 & 446 \\
\hline Borealis & Químico e Petroquímica & 145 & 260 \\
\hline Carbocloro & Químico e Petroquímica & 0 & 0 \\
\hline Clariant & Químico e Petroquímica & 579 & 727 \\
\hline Syngenta & Químico e Petroquímica & 147 & 426 \\
\hline Bayer & Químico e Petroquímica & 2655 & 3162 \\
\hline Comgás & Químico e Petroquímica & 0 & 0 \\
\hline Repsol YPF Brasil & Químico e Petroquímica & 29 & 30 \\
\hline
\end{tabular}




\begin{tabular}{|c|c|c|c|}
\hline Tenaris Confab & Químico e Petroquímica & 0 & 0 \\
\hline Aços Villares & Siderurgia & 0 & 0 \\
\hline Belgo Siderurgia S/A & Siderurgia & 0 & 0 \\
\hline IBM & TIC & 1962 & 1253 \\
\hline Tata & TIC & 0 & 4 \\
\hline AMD & TIC & 400 & 472 \\
\hline Dell & TIC & 0 & 0 \\
\hline Motorola & TIC & 1491 & 1599 \\
\hline Furukawa & TIC & 137 & 320 \\
\hline Siemens & TIC & 8010 & 10747 \\
\hline Nokia & TIC & 1772 & 3669 \\
\hline$L G$ & TIC & 158 & 1784 \\
\hline Nexans & TIC & 65 & 178 \\
\hline Freescale & TIC & 33 & 194 \\
\hline Adobe Systems & TIC & 91 & 24 \\
\hline CPM & TIC & 0 & 0 \\
\hline Ericsson & TIC & 1999 & 3534 \\
\hline $\mathrm{HP}$ & TIC & 2081 & 2880 \\
\hline Nortel Networks & TIC & 837 & 762 \\
\hline ST Microelectronics & TIC & 1489 & 1988 \\
\hline Texas Instruments S.T. & TIC & 1114 & 953 \\
\hline Alcatel & TIC & 2279 & 3169 \\
\hline Lucent & TIC & 2024 & 1816 \\
\hline Alcatel-Lucent & TIC & 4302 & 4979 \\
\hline Bosch & Veículos e peças & 3742 & 6981 \\
\hline Eaton & Veículos e peças & 666 & 517 \\
\hline Visteon & Veículos e peças & 29 & 244 \\
\hline Pirelli & Veículos e peças & 281 & 417 \\
\hline Delphi & Veículos e peças & 543 & 1701 \\
\hline Fiat & Veículos e peças & 301 & 450 \\
\hline Yamaha & Veículos e peças & 391 & 642 \\
\hline General Motors & Veículos e peças & 373 & 237 \\
\hline Ford & Veículos e peças & 1101 & 1075 \\
\hline Toyota & Veículos e peças & 1539 & 2014 \\
\hline Renault & Veículos e peças & 454 & 917 \\
\hline Dana Albarus & Veículos e peças & 0 & 0 \\
\hline Mahle Metal Leve & Veículos e peças & 58 & 125 \\
\hline Tower Automotive & Veículos e peças & 0 & 2 \\
\hline TRW Automotive & Veículos e peças & 184 & 429 \\
\hline ZF Sachs & Veículos e peças & 11 & 140 \\
\hline General Electric & Mecânica & 1474 & 2707 \\
\hline Intel & TIC & 306 & 1231 \\
\hline Microsoft & TIC & 190 & 1715 \\
\hline Total & & 67353 & 95920 \\
\hline
\end{tabular}


A tabela 5 retrata o número total de patentes registradas no EPO para empresas préselecionadas para o estudo. Praticamente todas as empresas tiveram aumentos significativos no número de patentes requisitada em escala global, tanto que no total houve um aumento de $42,41 \%$ de um período para o outro.

Os gráficos mostrados a seguir retratam a evolução do número de patentes requeridas no EPO nos dois períodos de coleta dos dados para alguns dos setores mais representativos: alimentos, farmacêutico e químico / petroquímico.

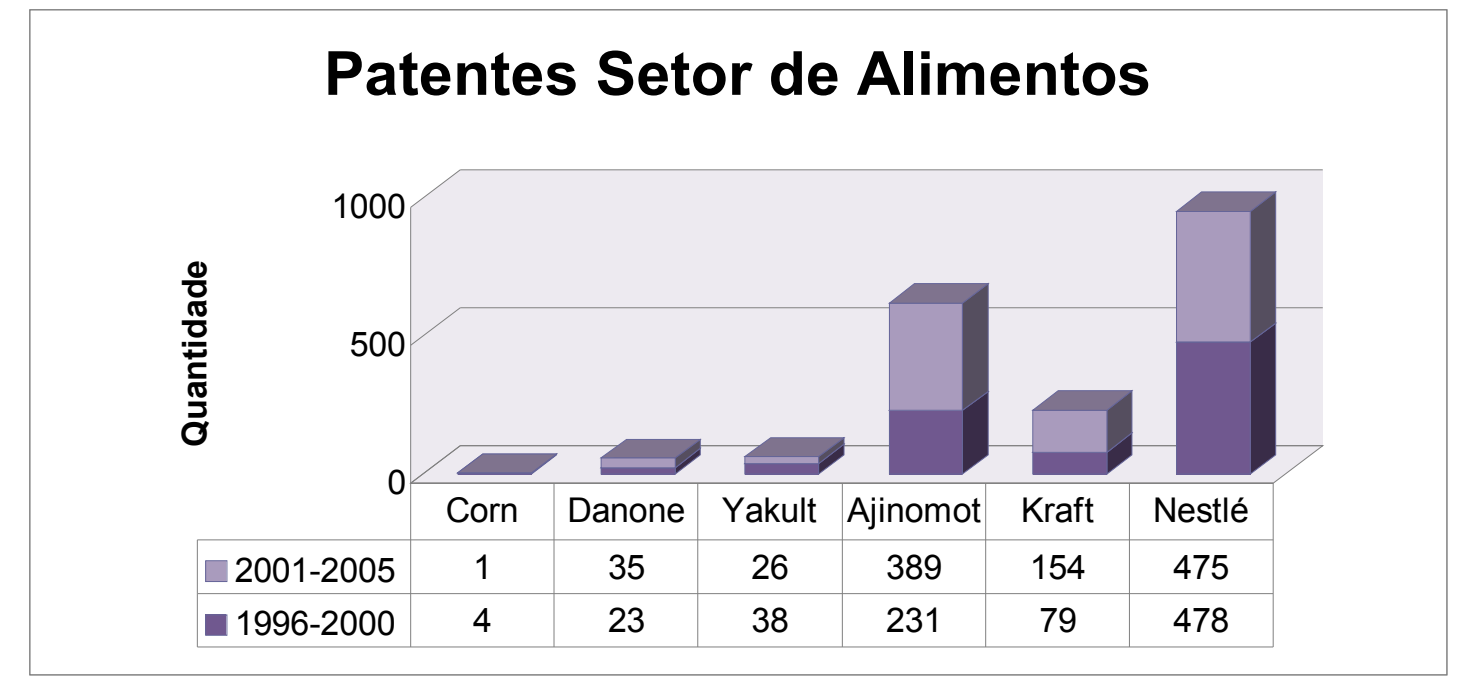

Gráfico 2 - Setor de Alimentos 


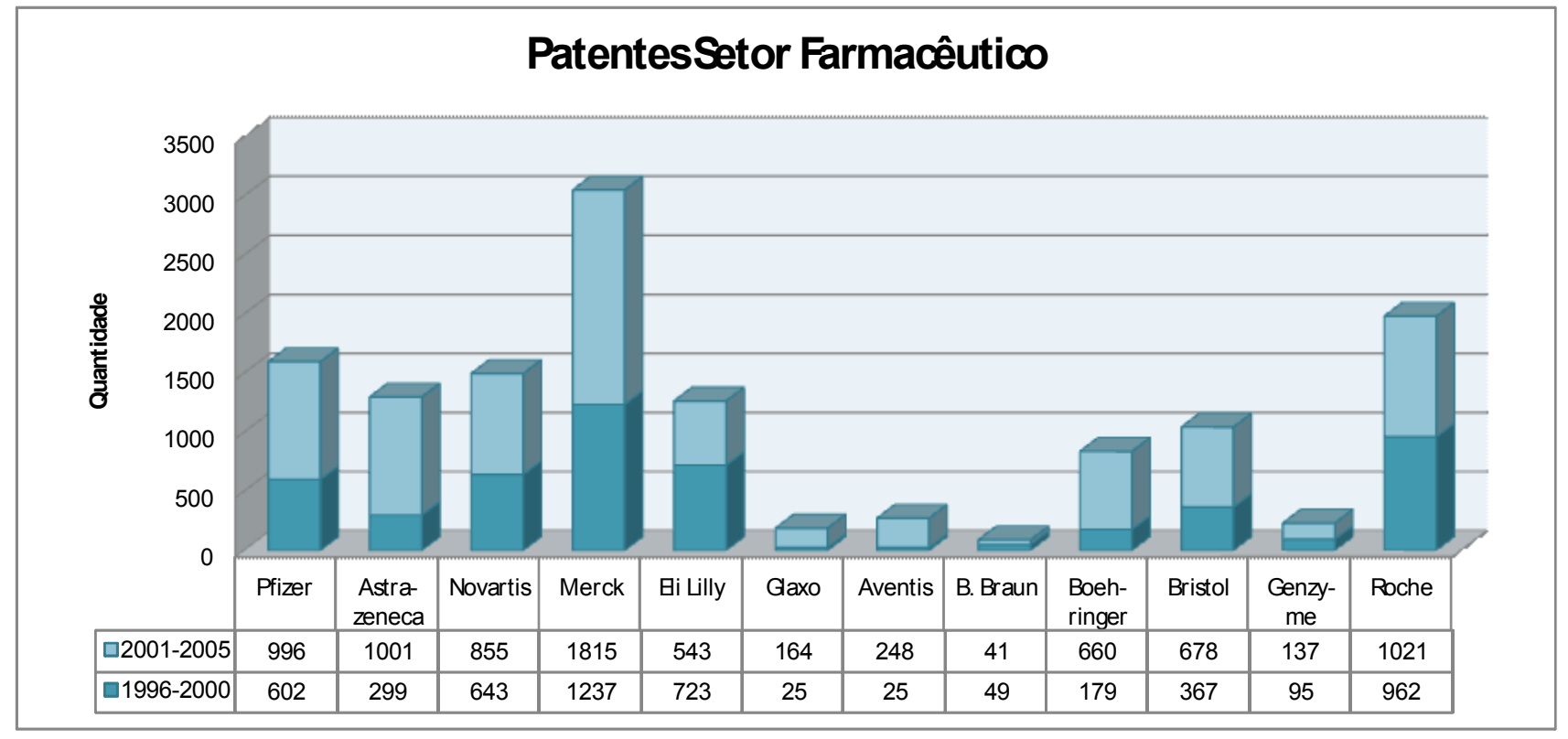

Gráfico 3 - Setor Farmacêutico

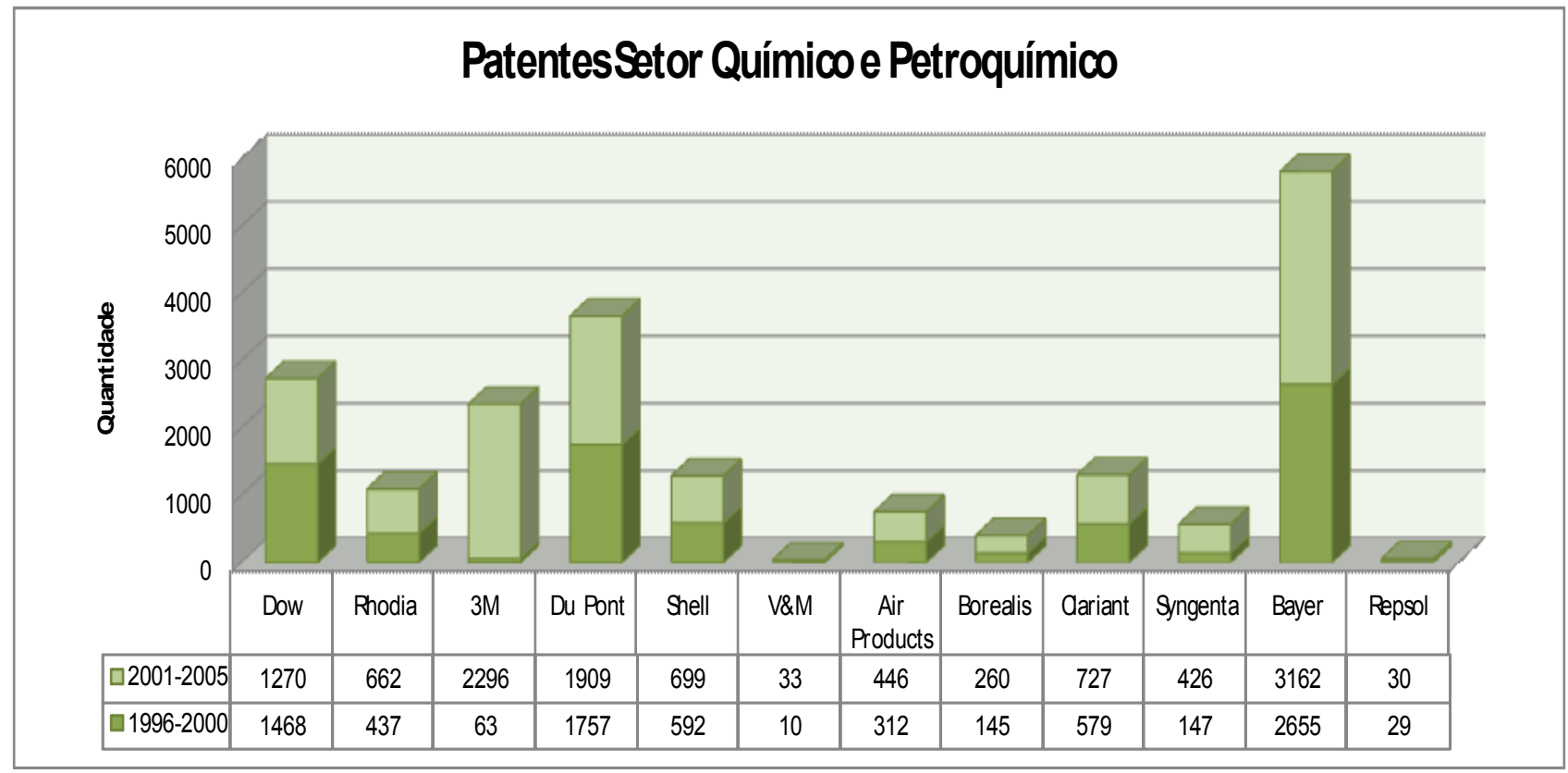

Gráfico 4 - Setor Petroquímico 
Alguns destaques: Kraft Foods, com um aumento no registro de patentes no EPO para inventores e solicitantes de todo o mundo de $94,9 \%$ entre um período e outro, Ajinomoto com 68,4\%, Astrazeneca que mais do que triplicou suas 299 patentes registradas de 1996 a 2000 no próximo período e Microsoft com um alargamento de 9 vezes no numero de patentes compensaram de forma satisfatória a queda de algumas nos registro de algumas empresas.

Dentre as empresas que diminuíram o número de suas patentes, vale citar algumas gigantes que incrivelmente requisitaram menos patentes no segundo período de estudo do que no primeiro, são elas: Eli Lilly (redução de 25\%), B. Braun (16,3\% a menos), Procter \& Gamble $(13,4 \%)$ e Texas Instruments $(14,6 \%)$. Aparecem ainda, com maior destaque, os números de Adobe Systems que saiu de suas 91 patentes entre 1996 e 2000 para apenas 24 nos anos de 2001 a 2005, totalizando um decréscimo de mais de 73\% e General Motors que marcou uma diminuição de $46,5 \%$ em seus pedidos de patentes com inventores e requisitantes de todo o mundo.

Após a análise geral dos dados totais coletados, este estudo se direciona para o ponto a que realmente se propõe: a consideração das situações das mesmas empresas para inventores e solicitantes de Brasil, Índia e China no que tange o numero de patentes registradas no European Patent Office.

Nessa etapa, é chocante a pouca representatividade que os países têm no contexto total de patentes requeridas no órgão. O Brasil, por exemplo, possui apenas 326 patentes com inventores residentes no país para os 10 anos de coleta de dados.

Para Brasil, assim como para Índia e China, foram levantados os dados de patentes para todas as 112 empresas mostradas na tabela de dados totais do EPO e que são consideradas a população desse estudo. No entanto, as tabelas abaixo mostram apenas 
aquelas empresas que obtiveram pelo menos um dos quatro campos da formatação adotada com resultado diferente de zero, ou seja, nas tabelas constam somente empresas com pelo menos uma patente com inventor residente no país ou da qual um dos solicitantes localizase no mesmo.

Tabela 6 - Situação do Brasil para Dados do EPO

\begin{tabular}{|c|c|c|c|c|c|}
\hline \multirow{5}{*}{$\begin{array}{l}\text { Empresa } \\
\text { Nestlé }\end{array}$} & \multirow{5}{*}{\begin{tabular}{|l} 
Setor \\
Alimentos
\end{tabular}} & \multicolumn{4}{|c|}{ Brasil } \\
\hline & & \multirow{2}{*}{\multicolumn{2}{|c|}{$\begin{array}{c}\text { Solicitante } \\
\text { EPO }\end{array}$}} & \multirow{2}{*}{\multicolumn{2}{|c|}{ Inventor }} \\
\hline & & & & EP & \\
\hline & & 1996-2000 & 2001-2005 & 1996-2000 & $2001-2005$ \\
\hline & & 0 & 0 & 1 & 3 \\
\hline Interprint & Comunicação e Gráfica & 2 & 0 & 2 & 0 \\
\hline Johnson \& Johnson & Cosmético e Higiene Pessoal & 10 & 24 & 10 & 24 \\
\hline Whirlpool & Eletroeletrônico & 25 & 94 & 25 & 93 \\
\hline Electrolux & Eletroeletrônico & 0 & 0 & 0 & 1 \\
\hline Merck & Farmacêutico & 0 & 0 & 0 & 1 \\
\hline Eli Lilly & Farmacêutico & 0 & 0 & 1 & 0 \\
\hline Saint Gobain & Materiais de Construção & 0 & 0 & 0 & 2 \\
\hline ABB & Mecânica & 0 & 0 & 0 & 1 \\
\hline Voith Siemens & Mecânica & 0 & 0 & 0 & 1 \\
\hline ThyssenKrupp & Mecânica & 0 & 0 & 0 & 1 \\
\hline Atlas Schindler & Mecânica & 1 & 1 & 1 & 1 \\
\hline Procter \& Gamble & Multisetor & 0 & 0 & 1 & 0 \\
\hline Unilever & Multisetor & 0 & 0 & 16 & 13 \\
\hline Aracruz Celulose & Papel e Celulose & 0 & 2 & 0 & 2 \\
\hline Voith Paper & Papel e Celulose & 0 & 0 & 6 & 16 \\
\hline Dow & Químico e Petroquímica & 0 & 0 & 0 & 3 \\
\hline Rhodia & Químico e Petroquímica & 0 & 3 & 2 & 5 \\
\hline Air Products Brasil Ltda & Químico e Petroquímica & 0 & 0 & 0 & 1 \\
\hline Clariant & Químico e Petroquímica & 0 & 0 & 3 & 9 \\
\hline Bayer & Químico e Petroquímica & 0 & 0 & 5 & 26 \\
\hline IBM & TIC & 0 & 0 & 1 & 1 \\
\hline Siemens & TIC & 1 & 1 & 5 & 1 \\
\hline Ericsson & TIC & 0 & 6 & 0 & 6 \\
\hline Alcatel-Lucent & TIC & 0 & 0 & 1 & 0 \\
\hline Bosch & Veículos e peças & 0 & 0 & 3 & 6 \\
\hline Eaton & Veículos e peças & 1 & 0 & 2 & 3 \\
\hline Pirelli & Veículos e peças & 2 & 2 & 4 & 6 \\
\hline General Motors & Veículos e peças & 1 & 0 & 2 & 0 \\
\hline Ford & Veículos e peças & 0 & 1 & 0 & 1 \\
\hline Mahle Metal Leve & Veículos e peças & 0 & 2 & 0 & 2 \\
\hline
\end{tabular}




\begin{tabular}{|l|l|rrr|r|} 
TRW Automotive & Veículos e peças & 0 & 0 & 0 & 1 \\
\hline General Electric & Mecânica & 0 & 0 & 0 & 3 \\
\hline Microsoft & TIC & 0 & 0 & 0 & 1 \\
\hline Total & & $\mathbf{4 3}$ & $\mathbf{1 3 6}$ & $\mathbf{9 2}$ & $\mathbf{2 3 4}$ \\
\hline
\end{tabular}

Mesmo com os significativos aumentos para solicitantes (216\%) e inventores (154\%) entre os períodos de estudos, a situação do Brasil é pouco confortável. Para se ter uma idéia, as 505 patentes de inventores ou solicitantes do país nos 10 anos de coleta de dados representam apenas $0,3 \%$ do total de requisições de registro ao EPO no mesmo período. Tanto que de todas as empresas pesquisadas, apenas 36 patentearam algum produto ou processo por intermédio do Brasil.

A situação fica ainda pior se forem desconsiderados os dados da Whirpool, empresa detentora de marcas consagradas no mercado nacional como Brastemp e Cônsul. A Whirpool, apesar de ter capital estrangeiro - ponto determinante para fazer parte desse trabalho - cresceu no Brasil graças a aquisições de empresas originalmente brasileiras e por isso manteve os centros de pesquisa e os métodos de trabalho dessas empresas sempre operantes, o que deixa a empresa em uma situação que foge do comum e precisa ler destacada para o correto andamento das analises.

Merecem destaque por apresentarem números mais substanciosos para o Brasil empresas como Johnson \& Johnson que teve 10 patentes com solicitante e inventor para o primeiro período de coleta de dados e 24 na mesma situação para o segundo. Unilever, que mesmo tendo apenas inventores brasileiros, teve 16 patentes no primeiro período e 13 no segundo, estando assim diretamente envolvida com país em 29 criações de inovações. E, por fim, Bayer, empresa que aumentou em $420 \%$ o número de inventores brasileiros de destaque e envolvidos em sua estratégia de P\&D. 
A situação chinesa para patentes no EPO é ainda pior que a brasileira, das 163.273 patentes registradas em esfera global pelas 112 empresas da população entre 1996 e 2005 , apenas 292 ou $0,18 \%$ delas têm inventores que residem na China ou foram requisitadas por subsidiárias das companhias que se localizam no país asiático.

Tabela 7 - Situação da China para Dados do EPO

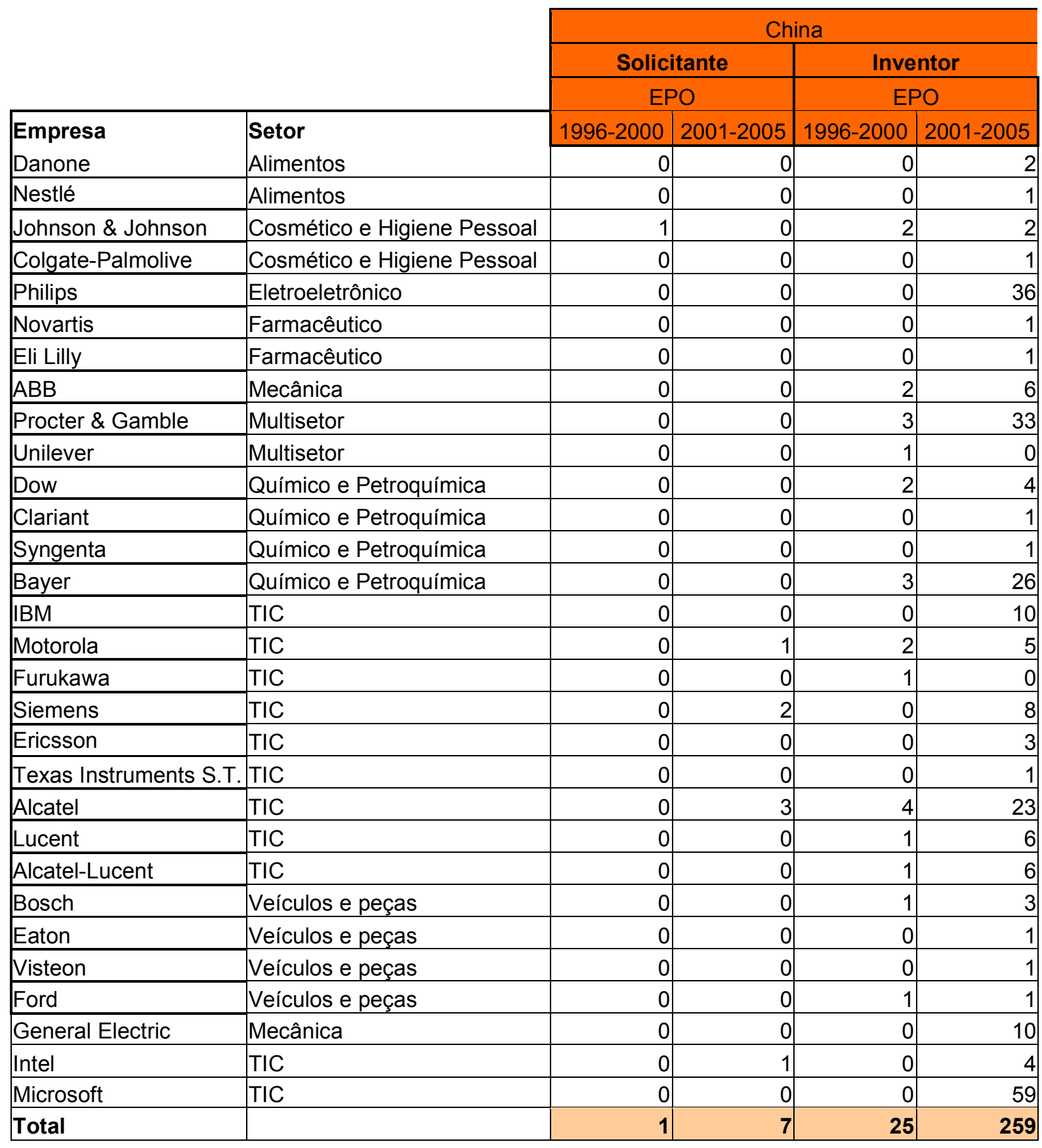


Para a China, ainda menos empresas das pré-selecionadas obtiveram dados diferentes de zero para esse estudo. Apenas 30 conseguiram desenvolver algo digno de um processo de patenteamento com inventores ou solicitantes chineses.

Assim como no caso do Brasil, a China também possui poucas empresas com destaque nesse indicador e a grande maioria delas com dados referentes unicamente a inventores envolvidos do estudo que originou a patente. Procter \& Gamble com 33 patentes, Philips com 36 e Microsoft com 59 são os grandes destaques. Todas elas apresentam tamanho salto quântico nos últimos anos do estudo, quando os inventores que moram na China chegaram a 259 contra 25 dos 5 anos anteriores.

A condição da Índia não foge à de Brasil e China para esta pesquisa, somente $0,17 \%$ das patentes mundiais requisitadas pelas empresas pesquisadas têm participação indiana em seu processo de desenvolvimento e apenas 33 dessas empresas aparecem na tabela abaixo com pelo menos uma patente com solicitante ou inventor que trabalham no país.

Tabela 8 - Situação da Índia para Dados do EPO

\begin{tabular}{|c|c|c|c|c|c|}
\hline & & \multicolumn{4}{|c|}{ Índia } \\
\hline & & \multicolumn{2}{|c|}{ Solicitante } & \multicolumn{2}{|c|}{ Inventor } \\
\hline & & \multicolumn{2}{|c|}{ EPO } & \multicolumn{2}{|c|}{ EPO } \\
\hline Empresa & Setor & 1996-2000 & 2001-2005 & 1996-2000 & 2001-2005 \\
\hline Ajinomoto & Alimentos & 0 & 0 & 1 & 0 \\
\hline Johnson \& Johnson & Cosmético e Higiene Pessoal & 0 & 4 & 0 & 5 \\
\hline Colgate-Palmolive & Cosmético e Higiene Pessoal & 0 & 0 & 0 & 1 \\
\hline Avon & Cosmético, Higiene Pessoal & 0 & 0 & 0 & 1 \\
\hline Pfizer & Farmacêutico & 0 & 0 & 0 & 1 \\
\hline Astrazeneca & Farmacêutico & 0 & 0 & 0 & 1 \\
\hline Novartis & Farmacêutico & 0 & 0 & 1 & 3 \\
\hline Merck & Farmacêutico & 0 & 0 & 0 & 1 \\
\hline Eli Lilly & Farmacêutico & 0 & 0 & 2 & 0 \\
\hline Sanofi Aventis & Farmacêutico & 0 & 0 & 0 & 1 \\
\hline Genzyme & Farmacêutico & 0 & 0 & 0 & 1 \\
\hline Saint Gobain & Materiais de Construção & 0 & 0 & 0 & 4 \\
\hline
\end{tabular}




\begin{tabular}{|l|l|r|r|r|r|}
\hline ABB & Mecânica & 0 & 0 & 0 & 1 \\
\hline ThyssenKrupp & Mecânica & 0 & 0 & 0 & 1 \\
\hline Procter \& Gamble & Multisetor & 0 & 0 & 5 & 3 \\
\hline Unilever & Multisetor & 0 & 0 & 12 & 36 \\
\hline Shell & Químico e Petroquímica & 0 & 0 & 1 & 0 \\
\hline Clariant & Químico e Petroquímica & 0 & 0 & 1 & 2 \\
\hline Bayer & Químico e Petroquímica & 0 & 0 & 0 & 2 \\
\hline IBM & TIC & 0 & 0 & 2 & 4 \\
\hline Tata & TIC & 0 & 4 & 0 & 3 \\
\hline Motorola & TIC & 0 & 0 & 0 & 3 \\
\hline Siemens & TIC & 0 & 0 & 0 & 11 \\
\hline Adobe Systems & TIC & 0 & 0 & 1 & 0 \\
\hline Ericsson & TIC & 0 & 0 & 0 & 1 \\
\hline ST Microelectronics & TIC & 0 & 14 & 1 & 15 \\
\hline Texas Instruments S.T. TIC & TIC & 0 & 0 & 13 & 17 \\
\hline Alcatel & TIC & 0 & 0 & 0 & 2 \\
\hline Lucent & TIC & 0 & 0 & 3 & 6 \\
\hline Alcatel-Lucent & Veículos e peças & 0 & 0 & 3 & 5 \\
\hline Bosch & Mecânica & 0 & 0 & 0 & 5 \\
\hline General Electric & TIC & 0 & 0 & 6 & 61 \\
\hline Intel & & 0 & 0 & 0 & 8 \\
\hline Total & & $\mathbf{2 2}$ & $\mathbf{5 2}$ & $\mathbf{2 0 5}$ \\
\hline
\end{tabular}

A Índia praticamente quadruplicou o número de inventores de um período para o outro e conseguiu sair do zero na coluna de solicitantes no primeiro período para 22 no segundo. Esse último avanço graças a 2 empresas o setor de Tecnologia de Informação (ST Microelectronics e Tata, sendo essa a única multinacional de origem indiana, que deve ser desconsiderada neste estudo) e uma de Cosméticos e Higiene que já havia se destacado no Brasil (Johnson \& Jonhson).

Tiveram números fora do "comum” para a situação indiana, ainda: Unilever, Texas Instruments e General Electric. Todas essas apresentando patentes apenas com inventores que residem na Índia e significativo crescimento de um espaço de tempo para o outro.

No que tange aos artigos publicados com ao menos um dos autores residente em Brasil, Índia ou China, a situação não é muito diferente. Apesar de números absolutos 
muito mais vultuosos, a participação dos 3 países continua pequena quando comparados com o total de artigos indexados na base do SCI.

A China apresenta a melhor posição entre os três paises, com 3,04\% da produção científica mundial no período de 1996 a 2005, a Índia encontra-se um pouco à frente do Brasil, com aproximadamente $1,8 \%$ do total e o Brasil, por sua vez, está em uma posição menos favorável com apenas $1,08 \%$ da produção mundial.

Tabela 9 - Dados Totais SCI para as Empresas Estudadas

\begin{tabular}{|l|l|c|}
\cline { 3 - 3 } \multicolumn{2}{l}{} & \multicolumn{1}{c}{ Setor } \\
\hline Empresa & & $1996-2005$ \\
\hline Ajinomoto & Alimentos & 5 \\
\hline Corn products & Alimentos & 0 \\
\hline Danone & Alimentos & 5 \\
\hline Kraft Foods & Alimentos & 3 \\
\hline Nestlé & Alimentos & 20 \\
\hline Yakult & Alimentos & 0 \\
\hline Souza Cruz & Bebidas e Fumo & 4 \\
\hline McDonald's & Comércio & 0 \\
\hline Lojas Renner & Comércio & 0 \\
\hline Submarino & Comércio & 0 \\
\hline American Banknote & Comunicação e Gráfica & 0 \\
\hline Interprint & Comunicação e Gráfica & 0 \\
\hline Colgate-Palmolive & Cosmético e Higiene Pessoal & 11 \\
\hline Johnson \& Johnson & Cosmético e Higiene Pessoal & 26 \\
\hline Avon & Cosmético, Higiene Pessoal & 0 \\
\hline Whirlpool & Eletroeletrônico & 0 \\
\hline Embraco & Eletroeletrônico & 9 \\
\hline Electrolux & Eletroeletrônico & 0 \\
\hline Mabe & Eletroeletrônico & 0 \\
\hline Tractebel & Energia Elétrica & 0 \\
\hline Energias do Brasil & Energia Elétrica & 0 \\
\hline Philips & Eletroeletrônico & 0 \\
\hline Coelce & Energia Elétrica & 0 \\
\hline AES & Energia Elétrica & 0 \\
\hline Astrazeneca & Farmacêutico & 0 \\
\hline B. Braun & Farmacêutico & 0 \\
\hline Boehringer Ingelheim & Farmacêutico & 0 \\
\hline Bristol Meyer & Farmacêutico & 0 \\
\hline Eli Lilly & Farmacêutico & 0 \\
\hline & & 0 \\
\hline
\end{tabular}




\begin{tabular}{|c|c|c|}
\hline GlaxoSmithKline & Farmacêutico & 47 \\
\hline Merck & Farmacêutico & 94 \\
\hline Novartis & Farmacêutico & 78 \\
\hline Pfizer & Farmacêutico & 60 \\
\hline Genzyme & Farmacêutico & 0 \\
\hline Roche & Farmacêutico & 61 \\
\hline Sanofi Aventis & Farmacêutico & 40 \\
\hline Holcim & Materiais de Construção & 0 \\
\hline Owens Illinois Brasil & Materiais de Construção & 0 \\
\hline Saint Gobain & Materiais de Construção & 8 \\
\hline Schuler & Mecânica & 0 \\
\hline Voith Siemens & Mecânica & 0 \\
\hline ThyssenKrupp & Mecânica & 0 \\
\hline Atlas Schindler & Mecânica & 0 \\
\hline ABB & Mecânica & 49 \\
\hline Alcoa & Metalurgia & 19 \\
\hline ESAB & Metalurgia & 3 \\
\hline Gonvarri & Metalurgia & 0 \\
\hline Alunorte & Metalurgia & 0 \\
\hline Villares Metals & Metalurgia & 6 \\
\hline Unilever & Multisetor & 59 \\
\hline Procter \& Gamble & Multisetor & 50 \\
\hline Aracruz Celulose & Papel e Celulose & 19 \\
\hline Bahia Pulp & Papel e Celulose & 0 \\
\hline International Paper & Papel e Celulose & 0 \\
\hline Voith Paper & Papel e Celulose & 1 \\
\hline Faber Castell S.A. & Plástico e Borracha & 1 \\
\hline $3 \mathrm{M}$ & Químico e Petroquímica & 12 \\
\hline Bayer & Químico e Petroquímica & 41 \\
\hline Clariant & Químico e Petroquímica & 1 \\
\hline Comgás & Químico e Petroquímica & 1 \\
\hline Dow & Químico e Petroquímica & 25 \\
\hline Vallourec \& Mannesmann & Químico e Petroquímica & 0 \\
\hline Air Products Brasil Ltda & Químico e Petroquímica & 0 \\
\hline Borealis & Químico e Petroquímica & 0 \\
\hline Carbocloro & Químico e Petroquímica & 0 \\
\hline Du Pont & Químico e Petroquímica & 4 \\
\hline Rhodia & Químico e Petroquímica & 22 \\
\hline Roullier & Químico e Petroquímica & 0 \\
\hline Shell & Químico e Petroquímica & 22 \\
\hline Repsol YPF Brasil & Químico e Petroquímica & 0 \\
\hline Tenaris Confab & Químico e Petroquímica & 0 \\
\hline Syngenta & Químico e Petroquímica & 14 \\
\hline Aços Villares & Siderurgia & 1 \\
\hline
\end{tabular}




\begin{tabular}{|c|c|c|}
\hline Belgo Siderurgia S/A & Siderurgia & 1 \\
\hline Adobe Systems & TIC & 1 \\
\hline AMD & TIC & 2 \\
\hline Alcatel & TIC & 27 \\
\hline CPM & TIC & 1 \\
\hline Dell & TIC & 1 \\
\hline Ericsson & TIC & 16 \\
\hline Furukawa & TIC & 9 \\
\hline HP Brasil & TIC & 9 \\
\hline Freescale & TIC & 0 \\
\hline IBM & $\mathrm{TIC}$ & 301 \\
\hline LG & TIC & 17 \\
\hline Lucent Technologies & TIC & 134 \\
\hline Motorola & TIC & 96 \\
\hline Nokia & TIC & 18 \\
\hline ST Microelectronics & TIC & 0 \\
\hline Nortel Networks & TIC & 13 \\
\hline Siemens & TIC & 53 \\
\hline Tata & TIC & 5500 \\
\hline Texas Instruments S.T. & TIC & 48 \\
\hline Bosch & Veículos e peças & 6 \\
\hline Dana Albarus & Veículos e peças & 2 \\
\hline Delphi & Veículos e peças & 5 \\
\hline Eaton & Veículos e peças & 14 \\
\hline Fiat & Veículos e peças & 10 \\
\hline Ford & Veículos e peças & 21 \\
\hline General Motors & Veículos e peças & 79 \\
\hline Pirelli & Veículos e peças & 4 \\
\hline Renault & Veículos e peças & 0 \\
\hline Toyota & Veículos e peças & 74 \\
\hline Mahle Metal Leve & Veículos e peças & 0 \\
\hline Tower Automotive & Veículos e peças & 0 \\
\hline TRW Automotive & Veículos e peças & 0 \\
\hline \begin{tabular}{|l|} 
Visteon \\
\end{tabular} & Veículos e peças & 3 \\
\hline Yamaha & Veículos e peças & 0 \\
\hline ZF Sachs & Veículos e peças & 1 \\
\hline TOTAL & & 7458 \\
\hline
\end{tabular}

À primeira vista, nota-se uma grande discrepância no número de artigos com autores ligados a companhia indiana Tata (tabela 9). Enquanto a maior parte das empresas 
possui dados com até duas casas decimais, a Tata tem 5500 artigos indexados no período que compreende apenas 10 anos.

A gigante empresa indiana, apesar de ser consideradas pelas bases utilizadas nesse estudo com atuante no setor TIC, também é muito forte em outros setores da economia e poderia ser facilmente classificado como uma companhia multi-setorizada. A Tata tem estruturas muito bem fundamentadas atuando nos ramos da siderurgia e na produção de automóveis, inclusive está engajada no desenvolvimento do carro mais barato do mundo, que custaria algo em torno de U\$2.500,00 e, por isso, vem sofrendo sanções das grandes empresas do setor com sedes na Europa, nos Estados Unidos e no Japão.

Pelo fato da Tata ser uma empresa que tem origem indiana, ela é alvo de muitos artigos acadêmicos de autores locais que utilizam a companhia como objeto de estudo, principalmente pela maior facilidade de contato com a matriz de uma multinacional. Inclusive, a maior parte desses artigos escritos por indianos não está diretamente atrelada às áreas de $\mathrm{P} \& \mathrm{D}$ da empresa, muitos deles estão apenas tratando de pontos administrativos da Tata ou são estudos-de-caso.

Por todos esse pontos, apesar de ser multinacional, a Tata foge do propósito da pesquisa. Assim como a Whirpool para o Brasil, a Tata é para a Índia nitidamente um "ponto fora da curva", os dados serão mostrados nas tabelas a seguir mas serão, por opção deste autor, desconsiderados nas analises qualitativas realizadas.

Tabela 10 - Situação do Brasil para Dados do SCI

\begin{tabular}{|l|l|c|c|}
\multicolumn{2}{c}{} & \multicolumn{2}{c|}{ Brasil } \\
\cline { 3 - 4 } \multicolumn{2}{c|}{} & \multicolumn{2}{c|}{ SCI/ISI } \\
\hline Empresa & \multicolumn{1}{c|}{ Setor } & $1996-2000$ & $\mathbf{2 0 0 1 - 2 0 0 5}$ \\
\hline Ajinomoto & Alimentos & 1 & 0 \\
\hline Danone & Alimentos & 1 & 1 \\
\hline
\end{tabular}




\begin{tabular}{|c|c|c|c|}
\hline Kraft Foods & Alimentos & 0 & 1 \\
\hline Nestlé & Alimentos & 6 & 4 \\
\hline Souza Cruz & Bebidas e Fumo & 1 & 3 \\
\hline Colgate-Palmolive & Cosmético e Higiene Pessoal & 2 & 3 \\
\hline Johnson \& Johnson & Cosmético e Higiene Pessoal & 3 & 6 \\
\hline Embraco & Eletroeletrônico & 1 & 8 \\
\hline Philips & Eletroeletrônico & 1 & 3 \\
\hline AES & Energia Elétrica & 0 & 2 \\
\hline Astrazeneca & Farmacêutico & 0 & 10 \\
\hline B. Braun & Farmacêutico & 0 & 1 \\
\hline Boehringer Ingelheim & Farmacêutico & 3 & 5 \\
\hline Eli Lilly & Farmacêutico & 1 & 14 \\
\hline GlaxoSmithKline & Farmacêutico & 0 & 18 \\
\hline Merck & Farmacêutico & 23 & 26 \\
\hline Novartis & Farmacêutico & 9 & 34 \\
\hline Pfizer & Farmacêutico & 5 & 18 \\
\hline Roche & Farmacêutico & 11 & 16 \\
\hline Sanofi Aventis & Farmacêutico & 1 & 14 \\
\hline Saint Gobain & Materiais de Construção & 2 & 2 \\
\hline ABB & Mecânica & 3 & 1 \\
\hline Alcoa & Metalurgia & 1 & 5 \\
\hline Villares Metals & Metalurgia & 3 & 3 \\
\hline Unilever & Multisetor & 1 & 4 \\
\hline Procter \& Gamble & Multisetor & 0 & 4 \\
\hline Aracruz Celulose & Papel e Celulose & 8 & 11 \\
\hline Faber Castell S.A. & Plástico e Borracha & 0 & 1 \\
\hline $3 \mathrm{M}$ & Químico e Petroquímica & 3 & 1 \\
\hline Bayer & Químico e Petroquímica & 4 & 7 \\
\hline Clariant & Químico e Petroquímica & 0 & 1 \\
\hline Comgás & Químico e Petroquímica & 1 & 0 \\
\hline Dow & Químico e Petroquímica & 0 & 1 \\
\hline Rhodia & Químico e Petroquímica & 10 & 12 \\
\hline Shell & Químico e Petroquímica & 5 & 2 \\
\hline Syngenta & Químico e Petroquímica & 0 & 9 \\
\hline Aços Villares & Siderurgia & 0 & 1 \\
\hline Belgo Siderurgia S/A & Siderurgia & 0 & 1 \\
\hline Alcatel & TIC & 2 & 4 \\
\hline CPM & TIC & 1 & 0 \\
\hline Ericsson & $\mathrm{TIC}$ & 1 & 3 \\
\hline Furukawa & TIC & 0 & 0 \\
\hline HP Brasil & TIC & 0 & 2 \\
\hline IBM & TIC & 21 & 23 \\
\hline Lucent Technologies & TIC & 19 & 5 \\
\hline Motorola & TIC & 3 & 7 \\
\hline
\end{tabular}




\begin{tabular}{|l|l|c|c|} 
Siemens & TIC & 3 & 3 \\
\hline Tata & TIC & 87 & 93 \\
\hline Texas Instruments S.T. & TIC & 0 & 7 \\
\hline Bosch & Veículos e peças & 0 & 1 \\
\hline Delphi & Veículos e peças & 0 & 1 \\
\hline Eaton & Veículos e peças & 4 & 1 \\
\hline Fiat & Veículos e peças & 0 & 10 \\
\hline Ford & Veículos e peças & 1 & 4 \\
\hline Pirelli & Veículos e peças & 1 & 3 \\
\hline Toyota & 1 & 1 \\
\hline \multicolumn{1}{|c|}{ TOTAL } & Veículos e peças & $\mathbf{2 5 4}$ & $\mathbf{4 2 1}$ \\
\hline
\end{tabular}

$\mathrm{Na}$ segregação por paises e períodos de analise dos dados, as tabelas ficam muito menores que aquela com os dados totais, isso porque neste indicador optou-se, também, por omitir aquelas companhias que não apresentam nenhum artigo para qualquer uma das etapas do estudo.

No caso dos artigos acadêmicos com autores ligados às companhias em estudo, o Brasil também mostrou um crescimento considerável, passou dos 254 que foram indexados entre 1996 e 2000 para 421 nos cinco anos seguintes, pontuando um aumento de 65,7\%.

Por características setoriais que são agregadas às especialidades técnicas de cada país, cada um dos três objetos desse estudo desenvolve algumas especialidades. No caso do Brasil, tem bastante destaque as empresas farmacêuticas, como Merck, Novartis, Pfizer e Roche. Apenas essas 4 grandes empresas do setor foram responsáveis por 142 artigos durante os 10 anos de analise. No entanto, muitos desses artigos gerados são referentes apenas a testes clínicos de produtos desenvolvidos em outros paises e nestes casos o Brasil é apenas campo de testes, não sendo realizada aqui nenhum tipo de pesquisa básica ou aplicada. 
Outro setor que sobressai quando o Brasil é visto isoladamente é Veículos e Peças. Mesmo sem nenhum destaque individual com muitos artigos envolvendo empresas desse setor, sete companhias têm ao menos um paper publicado na base do SCI.

A condição chinesa para dados bibliométricos é extremamente mais favorável que a brasileira, principalmente para o segundo período (2001 a 2005) desse levantamento, quando a China publicou mais que o dobro daquilo que autores brasileiros conseguiram (956 contra 421).

Tabela 11 - Situação da China para Dados do SCI

\begin{tabular}{|l|l|c|c|}
\multicolumn{2}{c}{} & \multicolumn{2}{c|}{ China } \\
\cline { 3 - 4 } \multicolumn{2}{l}{ Setor } & \multicolumn{2}{c|}{ SCI/II } \\
\hline Empresa & & $1996-2000$ & $\mathbf{2 0 0 1 - 2 0 0 5}$ \\
\hline Ajinomoto & Alimentos & 1 & 2 \\
\hline Danone & Alimentos & 1 & 6 \\
\hline Nestlé & Alimentos & 0 & 4 \\
\hline Colgate-Palmolive & Cosmético e Higiene Pessoal & 3 & 8 \\
\hline Johnson \& Johnson & Cosmético e Higiene Pessoal & 10 & 31 \\
\hline Philips & Eletroeletrônico & 0 & 11 \\
\hline Astrazeneca & Farmacêutico & 3 & 0 \\
\hline Boehringer Ingelheim & Farmacêutico & 3 & 25 \\
\hline Eli Lilly & Farmacêutico & 0 & 22 \\
\hline GlaxoSmithKline & Farmacêutico & 5 & 35 \\
\hline Merck & Farmacêutico & 5 & 19 \\
\hline Novartis & Farmacêutico & 4 & 24 \\
\hline Pfizer & Farmacêutico & 6 & 22 \\
\hline Roche & Farmacêutico & 1 & 13 \\
\hline Sanofi Aventis & Farmacêutico & 0 & 3 \\
\hline Saint Gobain & Materiais de Construção & 3 & 29 \\
\hline ABB & Mecânica & 3 & 9 \\
\hline Alcoa & Metalurgia & 2 & 0 \\
\hline ESAB & Metalurgia & 3 & 12 \\
\hline Unilever & Multisetor & 3 & 25 \\
\hline Procter \& Gamble & Multisetor & 0 & 1 \\
\hline Voith Paper & Papel e Celulose & 0 & 4 \\
\hline 3M & Químico e Petroquímica & 7 & 15 \\
\hline Bayer & Químico e Petroquímica & 3 & 20 \\
\hline Dow & Químico e Petroquímica & & 0 \\
\hline Du Pont & Químico e Petroquímica & 1 & \\
\hline
\end{tabular}




\begin{tabular}{|l|l|c|c|} 
& Químico e Petroquímica & 4 & 9 \\
\hline Syngenta & Químico e Petroquímica & 0 & 5 \\
\hline AMD & TIC & 0 & 2 \\
\hline Alcatel & TIC & 1 & 16 \\
\hline Ericsson & TIC & 5 & 5 \\
\hline Furukawa & TIC & 1 & 8 \\
\hline IBM & TIC & 13 & 75 \\
\hline LG & TIC & 3 & 3 \\
\hline Lucent Technologies & TIC & 11 & 41 \\
\hline Motorola & TIC & 8 & 44 \\
\hline Nokia & TIC & 2 & 12 \\
\hline Nortel Networks & TIC & 2 & 7 \\
\hline Siemens & TIC & 12 & 18 \\
\hline Tata & TIC & 148 & 277 \\
\hline Texas Instruments S.T. & TIC & 1 & 2 \\
\hline Bosch & Veículos e peças & 2 & 2 \\
\hline Delphi & Veículos e peças & 1 & 3 \\
\hline Eaton & Veículos e peças & 2 & 6 \\
\hline Ford & Veículos e peças & 3 & 9 \\
\hline General Motors & Veículos e peças & 7 & 21 \\
\hline Toyota & Veículos e peças & 17 & 48 \\
\hline Visteon & Veículos e peças & 3 & 0 \\
\hline ZF Sachs & Veículos e peças & 0 & 1 \\
\hline & & & \\
\hline & & & \\
\hline
\end{tabular}

A evolução da China como uma nova economia de mercado fica clara ao se observar a tabela 11. De um período ao outro, o número de artigos publicados com autores chineses para as empresas da população estudada mais do que triplicou, sendo assim de longe o maior crescimento entre os paises foco desse trabalho acadêmico.

O desenvolvimento de novas tecnologias passou a fazer parte da vida dos chineses e, conseqüentemente, surgiu interesse por escrever sobre esses temas. Foram publicados 198 artigos com empresas farmacêuticas, 717 com empresas do setor de Tecnologia da Informação e 125 com especializadas em Veículos e Peças.

Em relação à evolução da situação de cada uma das empresas pesquisadas, é muito difícil eleger aquelas que mais sobressaíram, isso devido à nova conjuntura econômica que 
se estabeleceu de forma concreta a partir da segunda metade da coleta dos dados, praticamente todas as companhias tiveram avanços de grandes proporções de um período para o outro.

Tabela 12 - Situação da Índia para Dados do SCI

\begin{tabular}{|c|c|c|c|}
\hline \multirow[b]{3}{*}{ Empresa } & \multirow[b]{3}{*}{ Setor } & \multicolumn{2}{|c|}{ Índia } \\
\hline & & \multicolumn{2}{|c|}{ SCI/ISI } \\
\hline & & $1996-2000$ & 2001-2005 \\
\hline Ajinomoto & Alimentos & 0 & 1 \\
\hline Kraft Foods & Alimentos & 1 & 1 \\
\hline Nestlé & Alimentos & 1 & 2 \\
\hline Colgate-Palmolive & Cosmético e Higiene Pessoal & 1 & 1 \\
\hline Johnson \& Johnson & Cosmético e Higiene Pessoal & 1 & 5 \\
\hline Philips & Eletroeletrônico & 3 & 17 \\
\hline Astrazeneca & Farmacêutico & 2 & 17 \\
\hline Eli Lilly & Farmacêutico & 0 & 9 \\
\hline GlaxoSmithKline & Farmacêutico & 0 & 7 \\
\hline Merck & Farmacêutico & 3 & 2 \\
\hline Novartis & Farmacêutico & 5 & 6 \\
\hline Pfizer & Farmacêutico & 3 & 6 \\
\hline Roche & Farmacêutico & 2 & 4 \\
\hline Sanofi Aventis & Farmacêutico & 0 & 11 \\
\hline Saint Gobain & Materiais de Construção & 1 & 0 \\
\hline $\mathrm{ABB}$ & Mecânica & 6 & 7 \\
\hline Alcoa & Metalurgia & 0 & 1 \\
\hline ESAB & Metalurgia & 1 & 0 \\
\hline Unilever & Multisetor & 17 & 22 \\
\hline Procter \& Gamble & Multisetor & 2 & 16 \\
\hline $3 \mathrm{M}$ & Químico e Petroquímica & 0 & 4 \\
\hline Bayer & Químico e Petroquímica & 5 & 3 \\
\hline Du Pont & Químico e Petroquímica & 1 & 0 \\
\hline Shell & Químico e Petroquímica & 2 & 0 \\
\hline Adobe Systems & TIC & 0 & 1 \\
\hline Alcatel & $\mathrm{TIC}$ & 0 & 4 \\
\hline Dell & TIC & 0 & 1 \\
\hline Ericsson & TIC & 0 & 2 \\
\hline HP Brasil & TIC & 0 & 7 \\
\hline Freescale & TIC & 0 & 0 \\
\hline IBM & TIC & 40 & 129 \\
\hline LG & $\mathrm{TIC}$ & 6 & 5 \\
\hline Lucent Technologies & TIC & 28 & 30 \\
\hline Motorola & TIC & 22 & 12 \\
\hline
\end{tabular}




\begin{tabular}{|l|l|c|c|} 
Nokia & TIC & 1 & 3 \\
\hline Nortel Networks & TIC & 1 & 3 \\
\hline Siemens & TIC & 13 & 4 \\
\hline Tata & TIC & 2246 & 2649 \\
\hline Texas Instruments S.T. & TIC & 18 & 20 \\
\hline Bosch & Veículos e peças & 1 & 0 \\
\hline Dana Albarus & Veículos e peças & 0 & 2 \\
\hline Delphi & Veículos e peças & 0 & 0 \\
\hline Eaton & Veículos e peças & 1 & 0 \\
\hline Ford & Veículos e peças & 3 & 1 \\
\hline General Motors & Veículos e peças & 26 & 25 \\
\hline Toyota & Veículos e peças & 1 & 6 \\
\hline \multicolumn{1}{|c|}{ TOTAL } & & & $\mathbf{2 4 6 4}$ \\
\hline
\end{tabular}

A primeira e mais importante observação que a tabela 12 demanda diz respeito a empresa Tata, como já foi explicado anteriormente, os dados dessa companhia distorcem totalmente qualquer analise a que essa dissertação possa se propor e isso fica claro quando os artigos envolvendo essa empresa são conflitados com aqueles envolvendo todas as outras empresas da população.

Entre os anos de 1996 e 2000, 2.464 artigos foram publicados com autores residentes na Índia e com ligação a alguma das 112 empresas pré-escolhidas. No entanto, $90,9 \%$ desses artigos referem-se à Tata e desta forma, o resultado que parecia impressionante frente aos outros dois paises pesquisados, se torna irrisório quando excluise a Tata da analise. A Índia passa a ter somente 218 papers.

Para o intervalo entre 2001 e 2005, acontece algo muito semelhante. Os 3.046 artigos se transformam em 397 quando se ignoram dados referentes à multinacional indiana e deixam a Índia em uma condição muito parecida com a do Brasil.

Apesar desse contratempo, as informações em que os dados coletados foram transformados ressaltam a vocação dos indianos para setores ligados ao desenvolvimento de softwares e à computação como um todo. A IBM, por exemplo, chegou a ter 40 artigos 
no primeiro período e 129 no segundo, ótimos resultados não só para os padrões indianos, mas também para Brasil e China.

Como pode ser observado nas tabelas e nas analises realizadas, são mais ou menos as mesmas companhias que aparecem nas tabelas referentes aos três paises estudados e aos artigos indexados e patentes requeridas. Isso revela que realmente há empresas que investem em Pesquisa e Desenvolvimento globais, o próximo tópico dessa dissertação procurará mostrar se existe relação entre as pesquisa que originaram os artigos e as patentes conquistadas para cada um dos três países.

\section{2 - ÁREAS DO CONHECIMENTO: PATENTES X ARTIGOS}

Como o intuito principal dessa parte do trabalho é analisar se as empresas selecionadas apresentam ligação entre as áreas escolhidas para publicação de artigos com autores ligados a elas e as áreas de conhecimento referente ao registro de suas patentes, diversas empresas tiveram que ser descartadas, mesmo depois de todos os dados serem pesquisados e coletados. Para a formulação desta seção, foram utilizados apenas dados das empresas que apresentavam artigos publicados por autores de pelo menos um dos paises estudados e, ao mesmo tempo, patentes registradas com solicitantes ou inventores de Brasil, Índia ou China.

Assim, das mais de cem empresas que estavam sendo utilizadas por este estudo até então, restaram somente trinta e nove que possuem os requisitos necessários para essa comparação, ou seja, empresas em que se é possível conferir se as áreas do conhecimento das patentes são as mesmas que as áreas dos artigos publicados. Restaram apenas as 
companhias que têm ao menos um artigo e uma patente em Brasil, Índia ou China para um dos períodos de coleta dos dados.

Tabela 13 - Empresas Utilizadas

\begin{tabular}{|l|l|l|l|}
\hline Danone & Eli Lilly & Clariant & Texas Instruments S.T. \\
\hline Ajinomoto & Sanofi Aventis & Syngenta & Alcatel \\
\hline Nestlé & Saint Gobain & Bayer & Lucent \\
\hline Johnson \& Johnson & ABB & IBM & Alcatel-Lucent \\
\hline Colgate-Palmolive & Procter \& Gamble & Motorola & Bosch \\
\hline Philips & Unilever & Furukawa & Eaton \\
\hline Astrazeneca & Aracruz Celulose & Siemens & Visteon \\
\hline Novartis & Voith Paper & Adobe Systems & Pirelli \\
\hline Merck & Dow & Ericsson & General Motors \\
\hline Shell & Rhodia & HP & Ford \\
\hline
\end{tabular}

Tendo em vista possibilitar a comparação entre as áreas de conhecimento dos dados bibliométricos e das patentes, foi preciso criar uma forma de analisar todas as informações sobre a mesma óptica. $\mathrm{O}$ grande contratempo encontrado para isso foi que logo à primeira vista, fica claro que as metodologias de classificação de áreas de conhecimento da Classificação Internacional de Patentes (CIP) e a utilizadas pelo SCI são completamente diferentes.

Enquanto o SCI classifica seus artigos de forma ampla e sucinta, a CIP é extremamente detalhada e repleta de opções de áreas para o registro da patente. Ainda, a classificação utilizada para os dados bibliométricos é muito focada em cada vertente das ciências exatas e pouco trata de humanidades, por exemplo, enquanto que na CIP, muitos campos das ciências tiveram que ser tratados de forma agregada para que a pesquisa tivesse representação estatística. 
Tabela 14 - Áreas do conhecimento SCI

Tecnologia agrícola \& de Alimentos

Astronomia

Ciências comportamentais

Instrumentação

Bioquímica

Ciências de Materiais

Biologia

Ciências biomédicas

Química

Ciências Computacionais

Matemática

Medicina

Microbiologia

Ciência Nuclear

Eletrônica

Farmacologia

Física

Engenharia

Psiquiatria e Psicologia

Estatísticas \& Probabilidade

Ciências do Meio Ambiente

Tecnologia \& Ciências aplicadas

Genética Medicina Veterinária

Geociências

Zoologia

Tabela 15 - Áreas do conhecimento baseadas na classificação internacional de patentes

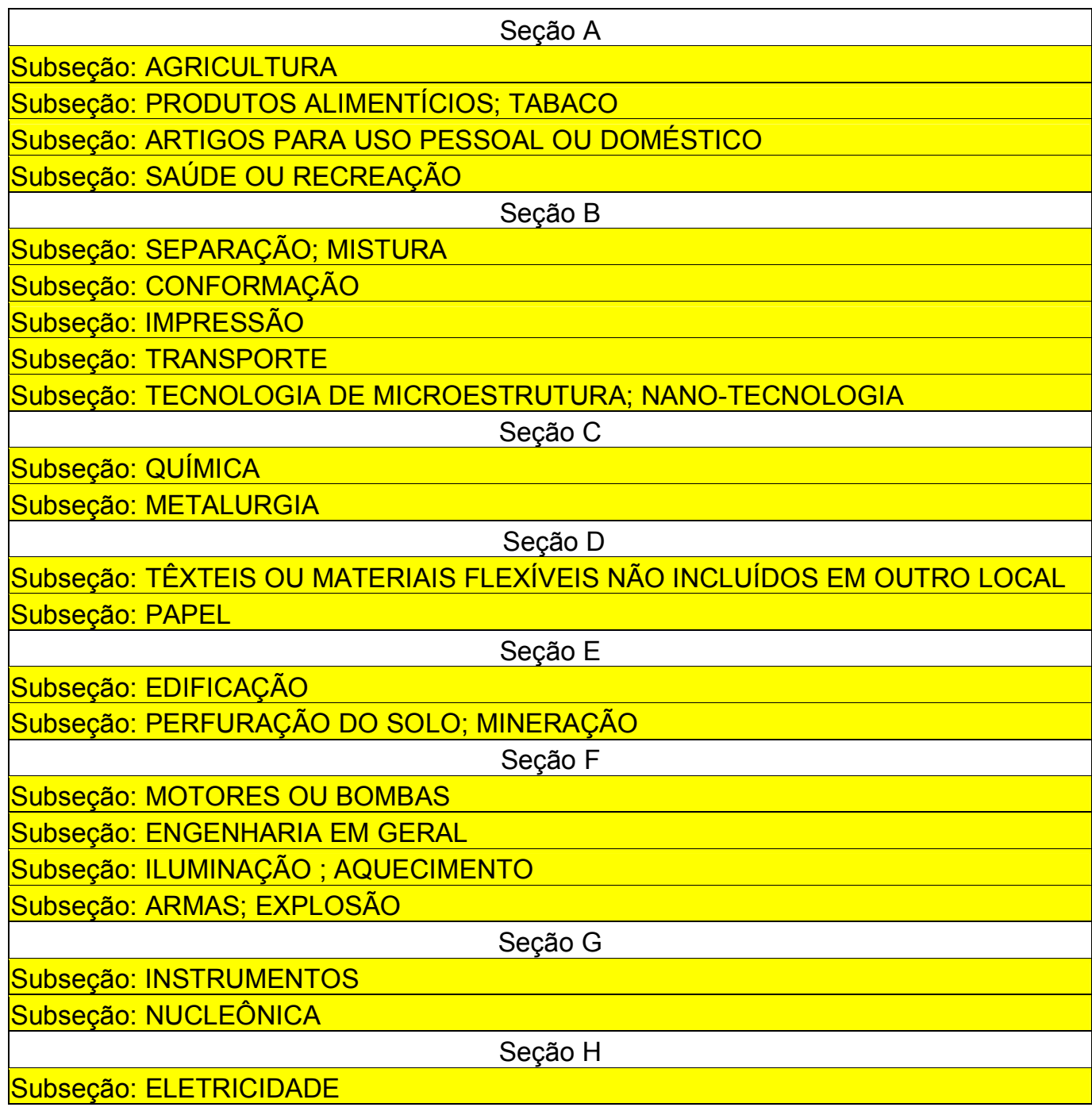


Por essa última classificação ser muito mais completa, o que dá mais embasamento para o trabalho realizado, optou-se por tentar classificar todos os 1.568 artigos de acordo com essas subseções que nas CIP são classificados pelos 3 primeiros dígitos, sendo uma letra e dois números ( $\mathrm{A} 21$, por exemplo).

A classificação qualitativa dos artigos dentro da classificação disponibilizada pelo EPO exigiu a leitura de todos os títulos, palavras-chaves e, em muitos casos, resumos e textos completos de todos os artigos. De qualquer forma, muitos deles foram claramente direcionados para uma das grandes áreas do conhecimento utilizadas por esse estudo, outros, no entanto, foram classificados dentro das áreas das quais mais de aproximavam ou colocados em mais de uma área quando o autor julgou necessário para representar o conteúdo do artigo.

A ferramenta estatística escolhida para medir a ligação entre as áreas de conhecimento dos artigos e das patentes para cada um dos paises foi a Correlação. Essa ferramenta é utilizada quando se deseja analisar duas variáveis de medida, de modo a determinar se elas tendem a se deslocar de forma coordenada.

Uma correlação próxima a zero indica que as duas variáveis não estão relacionadas. Uma correlação positiva indica que as duas variáveis se movem no mesmo sentido e a relação é mais forte quanto maior for o índice. Uma correlação negativa indica que as duas variáveis se movem em direções opostas. Em suma, duas variáveis que estão perfeitamente correlacionadas positivamente $(\mathrm{r}=1)$ avançam em perfeita proporção e na mesma direção, enquanto que, dois conjuntos que estão perfeitamente correlacionados negativamente andam em perfeita proporção em direções opostas.

Feito todo esse trabalho, chegou-se aos seguintes resultados expressos nas tabelas a seguir que representam os dois períodos de estudos (1996 a 2000 e 2001 a 2005): 
Tabela 16 - Relação entre Artigos e Patentes no Brasil ( $1^{\circ}$ período )

\begin{tabular}{|l|r|r|}
\multicolumn{1}{c}{$1^{\circ}$ PERIODO } & \multicolumn{1}{c|}{ BRASIL } \\
\hline Área do Conhecimento & Patentes EPO & Artigos SCI \\
\hline & 5 & 1 \\
\hline AGRICULTURA & 6 & 8 \\
\hline PRODUTOS ALIMENTÍCIOS;TABACO & 0 & 0 \\
\hline ARTIGOS PARA USO PESSOAL OU DOMÉSTICO & 12 & 34 \\
\hline SAÚDE OU RECREAÇÃO & 4 & 0 \\
\hline SEPARAÇÃO; MISTURA & 3 & 0 \\
\hline CONFORMAÇÃO & 0 & 0 \\
\hline IMPRESSÃO & 3 & 0 \\
\hline TRANSPORTE & 0 & 0 \\
\hline TECNOLOGIA DE MICROESTRUTURA; NANO-TECNOLOGIA & 21 & 48 \\
\hline QUÍMICA & 0 & 1 \\
\hline METALURGIA & 2 & 0 \\
\hline TÊXTEIS OU MATERIAIS FLEXÍVEIS NÃO INCLUÍDOS EM OUTRO LOCAL & 6 & 1 \\
\hline PAPEL & 6 & 0 \\
\hline EDIFICAÇÃO & 0 & 0 \\
\hline PERFURAÇÃO DO SOLO; MINERAÇÃO & 0 & 1 \\
\hline MOTORES OU BOMBAS & 2 & 2 \\
\hline ENGENHARIA EM GERAL & 2 & 0 \\
\hline ILUMINAÇÃO; AQUECIMENTO & 0 & 1 \\
\hline ARMAS; EXPLOSÃO & 0 & 5 \\
\hline INSTRUMENTOS & 5 & 0 \\
\hline NUCLEÔNICA & 9 & \\
\hline ELETRICIDADE & & 0 \\
\hline
\end{tabular}

A tabela 16 mostra claramente as áreas em que são realizadas mais pesquisas de alto nível no Brasil e nas quais o país se destaca como formador de conhecimento. Química, engenharias e saúde são os principais geradores tanto de artigos indexados com autores residentes no Brasil como de patentes requisitadas por subsidiarias de multinacionais aqui instaladas.

Por outro lado, o Brasil também se mostra deficiente em outras áreas do conhecimento, nas quais não possui nenhuma expertise. Não apareceram artigos ou patentes desenvolvidos no país nesse primeiro período de analise para 7 das 22 áreas aqui trabalhadas. 
A correlação entre as áreas do conhecimento para Patentes no EPO e Artigos no SCI para o Brasil nesse primeiro período foi altíssima, chegando a 0,872660. Esse valor encontrado retrata que, durante esse período de coleta de dados, a grande maioria das pesquisas que resultaram em artigos acadêmicos eram referentes às mesmas áreas de estudo que acabaram gerando patentes que foram registradas no EPO.

Tabela 17 - Relação entre Artigos e Patentes no Brasil ( $2^{\circ}$ período )

\begin{tabular}{|c|c|c|}
\hline $2^{\circ} \mathrm{PERIODO}$ & BRASIL & BRASIL \\
\hline Área do Conhecimento & Patentes EPO & Artigos SCl \\
\hline AGRICULTURA & 27 & 24 \\
\hline PRODUTOS ALIMENTÍCIOS;TABACO & 5 & 4 \\
\hline ARTIGOS PARA USO PESSOAL OU DOMÉSTICO & 5 & 0 \\
\hline SAÚDE OU RECREAÇÃO & 28 & 108 \\
\hline SEPARAÇÃO; MISTURA & 5 & 1 \\
\hline CONFORMAÇÃO & 5 & 0 \\
\hline IMPRESSÃO & 2 & 1 \\
\hline TRANSPORTE & 12 & \\
\hline TECNOLOGIA DE MICROESTRUTURA; NANO-TECNOLOGIA & 0 & 0 \\
\hline QUÍMICA & 41 & 23 \\
\hline METALURGIA & 1 & 10 \\
\hline TÊXTEIS OU MATERIAIS FLEXÍVEIS NÃO INCLUÍDOS EM OUTRO LOCAL & 6 & 0 \\
\hline PAPEL & 16 & \\
\hline EDIFICAÇÃO & 0 & 0 \\
\hline PERFURAÇÃO DO SOLO; MINERAÇÃO & 0 & 0 \\
\hline MOTORES OU BOMBAS & 3 & 2 \\
\hline ENGENHARIA EM GERAL & 3 & 23 \\
\hline ILUMINAÇÃO ; AQUECIMENTO & 4 & 1 \\
\hline ARMAS; EXPLOSÃO & 0 & 0 \\
\hline INSTRUMENTOS & 4 & 7 \\
\hline NUCLEÔNICA & 0 & 3 \\
\hline ELETRICIDADE & 10 & 25 \\
\hline
\end{tabular}

No segundo período analisado, os números absolutos aumentaram muito para o Brasil, tanto nas patentes como nos artigos. No entanto, as áreas de destaque continuaram 
praticamente as mesmas, com química e saúde puxando a fila, seguidas de uma nova evidencia: as pesquisas sobre agricultura.

Edificação, perfuração de solo, armas e nano-tecnologia ficaram marcadas como as áreas em que os pesquisadores não conseguiram gerar nenhum artigo e nenhuma patente nas bases de dados pesquisadas, retratando o baixo investimento, se comparado a outros paises, no Brasil em pesquisas com esses temas.

Para esse segundo período de estudo, a correlação entre as variáveis foi mais baixa que no primeiro período, resultando 0,589944. Esse número mostra que houve uma diminuição na ligação entre as pesquisas que originaram artigos e aquelas que geraram patentes, no entanto, essa correlação ainda pode ser considerada alta, ou seja, há proporcionalidade entre as áreas de conhecimento dos 234 artigos e das 177 patentes coletadas.

Tabela 18 - Relação entre Artigos e Patentes na Índia ( $1^{\circ}$ período )

$1^{\circ}$ PERIODO

\section{ÍNDIA}

Área do Conhecimento

PRODUTOS ALIMENTÍCIOS;TABACO

ARTIGOS PARA USO PESSOAL OU DOMÉSTICO

SAÚDE OU RECREAÇÃO

SEPARAÇÃO; MISTURA

CONFORMAÇÃO

IMPRESSÃO

TRANSPORTE

TECNOLOGIA DE MICROESTRUTURA; NANO-TECNOLOGIA

QUÍMICA

METALURGIA

TÊXTEIS OU MATERIAIS FLEXÍVEIS NÃO INCLUÍDOS EM OUTRO LOCAL

PAPEL

EDIFICAÇÃO

PERFURAÇÃO DO SOLO; MINERAÇÃO

MOTORES OU BOMBAS

ENGENHARIA EM GERAL

\section{Patentes EPO}

Artigos SC 


\begin{tabular}{|l|r|r|}
\hline ILUMINAÇÃO; AQUECIMENTO & 0 & 3 \\
\hline ARMAS; EXPLOSÃO & 0 & 0 \\
\hline INSTRUMENTOS & 17 & 5 \\
\hline NUCLEÔNICA & 0 & 5 \\
\hline ELETRICIDADE & 9 & 28 \\
\hline
\end{tabular}

No caso da Índia, a situação entre 1996 e 2000 foi muito diferente da do Brasil, durante esse período, houve pouquíssima ligação entre os artigos coletados no SCI e as patentes do EPO, a correlação entre esses dados foi de apenas 0,225915. Para se ter uma idéia dessa ocorrência, foram publicados por indianos 102 artigos sobre engenharia em geral, contudo, nenhuma patente envolvendo alguma das vertentes desse tema foi requisitada.

Vale ressaltar que muitos desses artigos sobre engenharia em geral eram referentes a engenharia da computação e desenvolvimento de softwares, área de notória especialidade dos centros de pesquisa indianos, e esses produtos não são patenteáveis e sim protegidos por copyright. Está aí uma possível explicação para esse resultado excepcional.

Possuem ainda alta correlação as áreas de saúde, química e instrumentação, dando destaque para a avançada medicina do país asiático, que gera muitas pesquisas de relevância internacional.

Tabela 19 - Relação entre Artigos e Patentes na Índia ( $2^{\circ}$ período )

\begin{tabular}{|l|r|r|}
\multicolumn{1}{c|}{$2^{\circ}$ PERIODO } & \multicolumn{1}{c|}{ ÍNDIA } \\
\hline Área do Conhecimento & Patentes EPO & Artigos SCI \\
\hline & & \\
\hline AGRICULTURA & 0 & 2 \\
\hline PRODUTOS ALIMENTÍCIOS;TABACO & 9 & 2 \\
\hline ARTIGOS PARA USO PESSOAL OU DOMÉSTICO & 0 & 0 \\
\hline SAÚDE OU RECREAÇÃO & 16 & 62 \\
\hline SEPARAÇÃO; MISTURA & 1 & 0 \\
\hline CONFORMAÇÃO & 3 & 0 \\
\hline IMPRESSÃO & 4 & 7 \\
\hline TRANSPORTE & 5 & 0 \\
\hline
\end{tabular}




\begin{tabular}{|l|r|r|}
\hline TECNOLOGIA DE MICROESTRUTURA; NANO-TECNOLOGIA & 0 & 1 \\
\hline QUÍMICA & 29 & 31 \\
\hline METALURGIA & 0 & 2 \\
\hline TÊXTEIS OU MATERIAIS FLEXÍVEIS NÃO INCLUÍDOS EM OUTRO LOCAL & 2 & 0 \\
\hline PAPEL & 0 & 0 \\
\hline EDIFICAÇÃO & 0 & 2 \\
\hline PERFURAÇÃO DO SOLO; MINERAÇÃO & 0 & 0 \\
\hline MOTORES OU BOMBAS & 5 & 0 \\
\hline ENGENHARIA EM GERAL & 0 & 96 \\
\hline ILUMINAÇÃO; AQUECIMENTO & 2 & 0 \\
\hline ARMAS; EXPLOSÃO & 0 & 0 \\
\hline INSTRUMENTOS & 28 & 7 \\
\hline NUCLEÔNICA & 0 & 1 \\
\hline ELETRICIDADE & 44 & 10 \\
\hline
\end{tabular}

No período que compreende os anos de 2000 a 2005, os números de artigos e patentes indianos aumentam significativamente, cerca de $30 \%$, no entanto a analise da situação do país ficou muito semelhante.

O setor de softwares gerou muitos artigos acadêmicos e nenhuma patente no EPO, o que acabou derrubando o índice de correspondência entre as áreas de conhecimento mais pesquisadas na Índia para as variáveis selecionadas. A correlação para esse segundo período foi de apenas 0,179385. Todavia, se excluirmos os dados de artigos sobre engenharias, somente a titulo de curiosidade, a correlação entre artigos e patentes na Índia aumenta consideravelmente, chegando a 0,480277.

Aqui fica clara a definição da ferramenta estatística, grandes valores de uma variável tendem a estar associados a grandes valores da outra e pequenos valores de uma variável tendem a estar associados a pequenos valores da outra (correlação positiva). 
Tabela 20 - Relação entre Artigos e Patentes na China ( $1^{\circ}$ período )

\begin{tabular}{|c|c|c|}
\hline $1^{\circ}$ PERIODO & CHINA & CHINA \\
\hline Área do Conhecimento & Patentes EPO & Artigos SCl \\
\hline AGRICULTURA & 4 & \\
\hline PRODUTOS ALIMENTÍCIOS;TABACO & 0 & 1 \\
\hline ARTIGOS PARA USO PESSOAL OU DOMÉSTICO & 1 & 0 \\
\hline SAÚDE OU RECREAÇÃO & 3 & 23 \\
\hline SEPARAÇÃO; MISTURA & 3 & 0 \\
\hline CONFORMAÇÃO & 1 & 0 \\
\hline IMPRESSÃO & 0 & \\
\hline TRANSPORTE & 1 & 2 \\
\hline TECNOLOGIA DE MICROESTRUTURA; NANO-TECNOLOGIA & 0 & 1 \\
\hline QUÍMICA & 12 & 32 \\
\hline METALURGIA & 0 & 3 \\
\hline TÊXTEIS OU MATERIAIS FLEXÍVEIS NÃO INCLUÍDOS EM OUTRO LOCAL & 0 & \\
\hline PAPEL & 0 & \\
\hline EDIFICAÇÃO & 0 & \\
\hline PERFURAÇÃO DO SOLO; MINERAÇÃO & 0 & 0 \\
\hline MOTORES OU BOMBAS & 0 & \\
\hline ENGENHARIA EM GERAL & 1 & 43 \\
\hline ILUMINAÇÃO ; AQUECIMENTO & 0 & 0 \\
\hline ARMAS; EXPLOSÃO & 0 & 0 \\
\hline INSTRUMENTOS & 2 & 14 \\
\hline NUCLEÔNICA & 0 & \\
\hline ELETRICIDADE & 1 & 12 \\
\hline
\end{tabular}

A tabela 20 retrata a situação da China para o primeiro período da pesquisa. As áreas do conhecimento que apresentaram maior destaque para esse país foram praticamente as mesmas que mais geraram artigos e patentes para Brasil e Índia, o que demonstra a identidade parecida que os três paises têm e reforça o argumento dessa pesquisa .

Engenharia em geral, química e saúde ou recreação foram responsáveis por mais de $70 \%$ de todos os dados recolhidos para a China entre 1996 e 2000. Enquanto que 7 das áreas pré-selecionadas não obtiveram um artigo ou patente sequer.

Por todos esses motivos, a correlação entre as áreas de artigos e patentes para a China nesse primeiro período foi de 0,547001. Esse índice caracteriza uma ligação mediana 
entre as pesquisas que originaram patentes e aquelas que geraram artigos, situação pior que a brasileira, porém melhor que a da Índia.

Tabela 21 - Relação entre Artigos e Patentes na China ( $2^{\circ}$ período )

\begin{tabular}{|c|c|c|}
\hline $2^{\circ} \mathrm{PERIODO}$ & CHINA & CHINA \\
\hline Área do Conhecimento & Patentes EPO & Artigos SCl \\
\hline AGRICULTURA & 3 & 3 \\
\hline PRODUTOS ALIMENTÍCIOS;TABACO & 3 & 12 \\
\hline ARTIGOS PARA USO PESSOAL OU DOMÉSTICO & 12 & 0 \\
\hline SAÚDE OU RECREAÇÃO & 23 & 111 \\
\hline SEPARAÇÃO; MISTURA & 17 & 0 \\
\hline CONFORMAÇÃO & 4 & 0 \\
\hline IMPRESSÃO & 2 & 0 \\
\hline TRANSPORTE & 10 & 5 \\
\hline TECNOLOGIA DE MICROESTRUTURA; NANO-TECNOLOGIA & 0 & 0 \\
\hline QUÍMICA & 35 & 90 \\
\hline METALURGIA & 0 & 7 \\
\hline TÊXTEIS OU MATERIAIS FLEXÍVEIS NÃO INCLUÍDOS EM OUTRO LOCAL & 0 & 0 \\
\hline PAPEL & 0 & 0 \\
\hline EDIFICAÇÃO & 1 & 2 \\
\hline PERFURAÇÃO DO SOLO; MINERAÇÃO & 0 & 0 \\
\hline MOTORES OU BOMBAS & 3 & 8 \\
\hline ENGENHARIA EM GERAL & 1 & 85 \\
\hline ILUMINAÇÃO ; AQUECIMENTO & 0 & 2 \\
\hline ARMAS; EXPLOSÃO & 0 & 0 \\
\hline INSTRUMENTOS & 27 & 25 \\
\hline NUCLEÔNICA & 0 & 0 \\
\hline ELETRICIDADE & 52 & 35 \\
\hline
\end{tabular}

A última tabela desse capítulo diz respeito à China, no segundo período de analise dos dados referentes às patentes do EPO e aos artigos do SCI. Apesar do número de artigos e patentes para praticamente todas as áreas do conhecimento terem aumentado de forma considerável do primeiro período para o segundo, a correlação entre esses diminuiu um pouco, passou de 0,547001 para 0,516883 . 
A variação do índice no decorrer do tempo foi ínfima, o que reafirma a situação da China para suas pesquisas em um espaço maior de tempo (10 anos) e dá ainda mais credibilidade para os resultados expostos na tabela acima.

Para patentes, os setores que mais se destacaram foram: saúde ou recreação, química, instrumentos e eletricidade. Em relação aos dados bibliométricos, os mesmos três setores estão, também, entre os que mais geraram dados, juntamente com o de engenharia em geral, que por ser uma área mais ampla conseguiu 85 artigos entre 2001 e 2005.

Têm realce negativo em registro de patentes para a China, os setores de impressão, metalurgia, edificação, iluminação e aquecimento. Para dados bibliométricos, são pouco estudadas as áreas de artigos para uso pessoal ou doméstico, separação de misturas, impressão e conformação. Tendo ainda resultados nulos na China para ambas as variáveis as seguintes áreas do conhecimento: nano-tecnologia, têxteis ou materiais flexíveis, papel, perfuração do solo, mineração, armas e nucleônica.

O gráfico a seguir resume os dados das correlações encontradas entre as áreas do conhecimento pré-selecionadas para as patentes e os artigos indexados com autores ou requisitantes de Brasil, Índia e China para os 2 períodos de coleta de dados: 


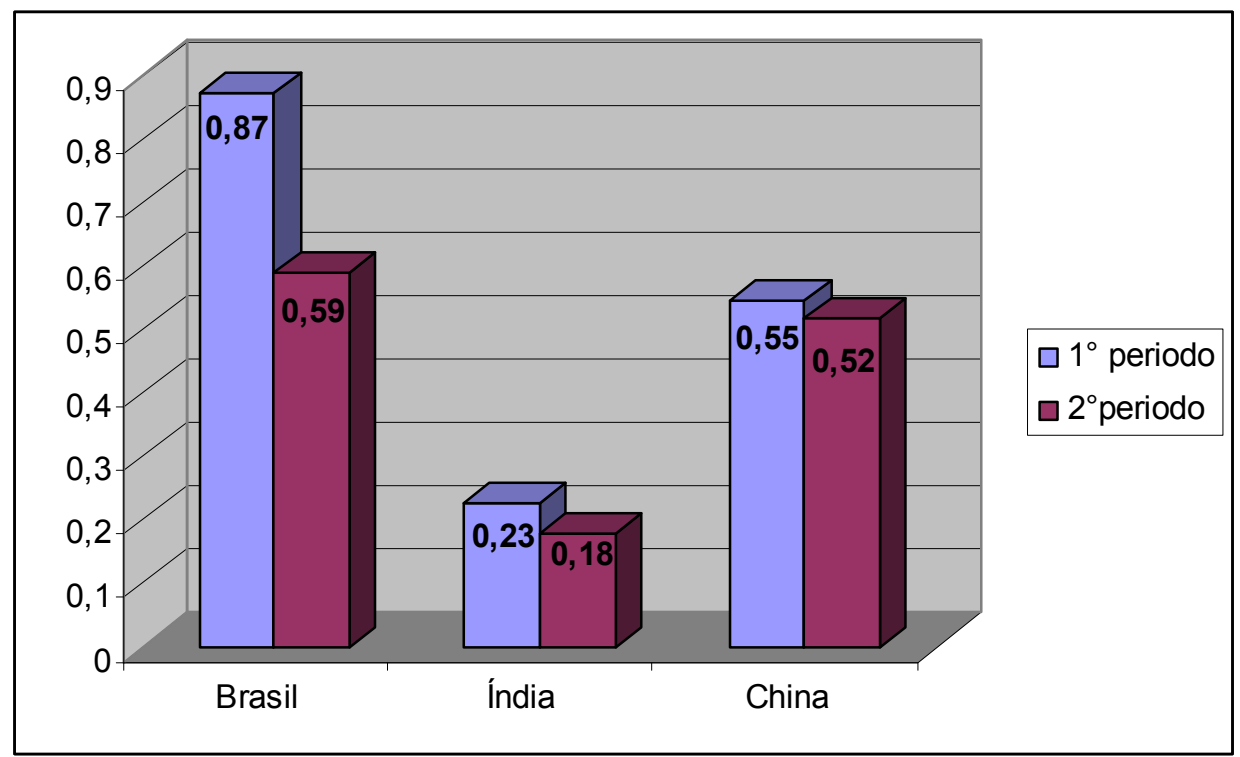

Gráfico 5 - Evolução da Correlação para Brasil, Índia e China

Surpreendentemente, todos os paises tiveram redução na correlação entre os temas das pesquisas realizadas que geraram patentes e artigos de um período para o outro, esse fato se deve, principalmente, ao aumento do número absoluto de dados após o ano 2001 e à conseqüente evolução das pesquisas em áreas que antes eram pouco estudadas.

No primeiro período de coleta de dados, os três paises concentravam muitas pesquisas em algumas poucas áreas - principalmente as mais simples. Depois disso, a evolução natural das economias e políticas de atração de investimentos fez com que fosse possível expandir os campos de estudo.

Setores como o de saúde e o de instrumentação passaram a ser mais pesquisados no Brasil, na Índia e na China e o sucesso alcançado pelos resultados do trabalho dos cientistas teve reconhecimento rápido, gerando muitas patentes e publicações.

Entretanto, na contra-mão dessa tendência de globalização das pesquisas, ainda estão setores como a nano-tecnologia e a nucleônica que tiveram pouquíssimos artigos 
publicados por autores dos três paises estudados e nenhuma patente foi encontrada sobre esses assuntos nos 10 anos de recolhimento dos dados.

A tabela 22 mostra a correlação entre as os artigos publicados por autores de Brasil, Índia e China e as patentes registradas pelas subsidiárias de empresas transnacionais instaladas nos três paises, para cada uma das áreas do conhecimento utilizadas nesse trabalho:

Tabela 22 - Correlação por área do conhecimento

\begin{tabular}{|l|c|c|}
\hline & 1996 a 2000 & 2001 a 2005 \\
\hline AGRICULTURA & & \\
\hline PRODUTOS ALIMENTÍCIOS; TABACO & $-0,277$ & 0,986 \\
\hline ARTIGOS PARA USO PESSOAL OU DOMÉSTICO & Não há relação & Não há relação \\
\hline SAÚDE OU RECREAÇÃO & 0,445 & 0,886 \\
\hline SEPARAÇÃO; MISTURA & Não há relação & $-0,277$ \\
\hline CONFORMAÇÃO & 0,500 & Não há relação \\
\hline IMPRESSÃO & Não há relação & 0,991 \\
\hline TRANSPORTE & $-0,945$ & 0,419 \\
\hline MICROESTRUTURA; NANO-TECNOLOGIA & Não há relação & Não há relação \\
\hline QUIMICA & 0,069 & $-0,109$ \\
\hline METALURGIA & Não há relação & 0,786 \\
\hline TÊXTEIS OU MATERIAIS FLEXIVEIS & Não há relação & Não há relação \\
\hline PAPEL & Não há relação & 1,000 \\
\hline EDIFICAÇÃO & Não há relação & Não há relação \\
\hline PERFURAÇÃO DO SOLO; MINERAÇÃO & Não há relação & Não há relação \\
\hline MOTORES OU BOMBAS & $-0,500$ & $-0,693$ \\
\hline ENGENHARIA EM GERAL & $-0,969$ & $-0,981$ \\
\hline ILUMINAÇÃO; AQUECIMENTO & Não há relação & $-0,500$ \\
\hline ARMAS; EXPLOSÃO & Não há relação & Não há relação \\
\hline INSTRUMENTOS & $-0,800$ & 0,468 \\
\hline NUCLEÔNICA & Não há relação & Não há relação \\
\hline ELETRICIDADE & 0,454 & 0,065 \\
\hline
\end{tabular}

Como pode ser observado, em muitos dos itens expressos na tabela acima não é possível traçar a correlação quando se busca discriminá-las por área do conhecimento, isso se deve ao fato de aqui os dados por país serem tratados de forma isolada em cada uma das áreas do conhecimento. Desta forma, nas subdivisões de áreas em que os três paises juntos 
não possuem nenhum artigo ou nenhuma patente para aquele período, não é possível encontrar a correlação entre essas áreas do conhecimento.

Não obstante, por apenas três paises - Brasil, Índia e China - estarem sendo tratados neste trabalho, uma analise visando a dinâmica demonstrada na tabela 22 seria infundada por insuficiência de dados. Assim, as correlações por área do conhecimento são aqui apresentadas somente a título de curiosidade. 


\section{3 - AS POLITICAS DE PATENTEAMENTO DAS EMPRESAS MULTINACIONAIS PARA AS SUBSIDIÁRIAS LOCALIZADAS NO BRASIL}

Como o objetivo principal do projeto da FAPESP de qual essa dissertação faz parte sempre foi desenvolver condições para que o Brasil receba investimentos mais substanciosos em P\&D, é extremamente importante que condição atual das subsidiárias de empresas transnacionais instaladas no Brasil seja traçada, até mesmo para que novas políticas de atração de IDE sejam planejadas. Desta forma, nesta seção é mostrado como essas filiais de empresas estrangeiras lidam com o desenvolvimento de produtos patenteáveis e até que ponto as matrizes incentivam as pesquisas em paises periféricos, no caso o Brasil.

Aqui são apresentados os resultados encontrados para o último objetivo específico desta dissertação - Investigar quais são as políticas voltadas ao patenteamento de empresas multinacionais para as subsidiárias localizadas no Brasil. Para tanto, foram realizadas entrevistas de caráter qualitativo com os gestores das áreas de Pesquisa e Desenvolvimento de algumas das empresas que foram alvo das análises anteriores.

Os principais critérios para a seleção de quais empresas seriam entrevistadas foram a condição de que essas empresas que investem ou que têm potencial para investirem em P\&D no país e a disponibilidade dos entrevistados de receber a equipe responsável pela pesquisa; até o fechamento dessa dissertação, dados de 47 subsidiárias brasileiras de multinacionais puderam ser usados e analisados. ${ }^{1}$

\footnotetext{
${ }^{1}$ Informações levantadas pela equipe do projeto da FAPESP (Ref: 03/06388-9) já mencionado.
} 
Seguindo o que foi acertado com as empresas entrevistadas e com os gestores que receberam a equipe responsável por essa etapa do projeto fomentado pela FAPESP, os nomes das transnacionais estão sendo mantidos em sigilo. Desta forma, procurando sempre mandar a confidencialidade dos dados, elas são tratadas genericamente ou com base no setor de atuação das mesmas.

Para simplificar o tratamento das respostas conseguidas, elas foram divididas em 5 grandes grupos e a partir daí analisadas individualmente. Essa segregação das respostas se deu pelo teor das informações passadas e pela interpretação do que foi dito, como é observado no gráfico 6 :

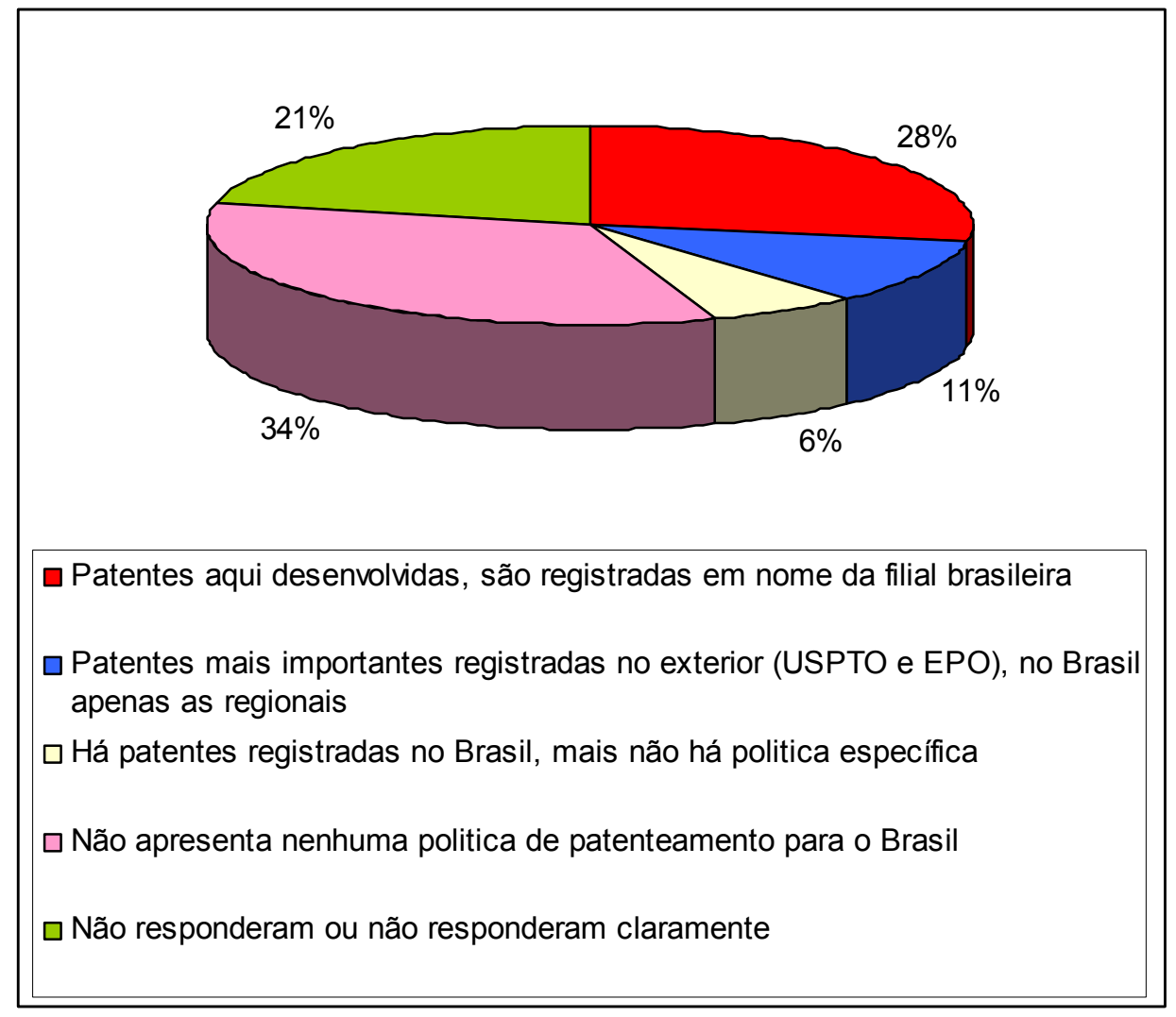

Gráfico 6 -Políticas de patenteamento para o Brasil 
Pode-se observar que uma grande parte das empresas que responderam o questionário (61\% do total) não apresenta política alguma de patenteamento desenvolvida para o Brasil. Dentre essas empresas, algumas (6\% delas) até possuem patentes registradas em nome da filial brasileira, mas sem qualquer política específica de incentivo a esse fim.

Casos como o descrito acima não são exclusividade de apenas alguns setores de atuação das empresas estudadas, há relatos de situações como essa em empresas dos setores de energia elétrica, tecnologia de informação e atuantes no setor de autopeças, por exemplo, que apresentam patentes registradas no Brasil, mas não dispõe de nenhuma política ou incentivo interno da companhia para isso.

Pelo outro lado, foi constatado que 13 empresas, aproximadamente $35 \%$ do total da amostra, apresentam políticas e patentes registradas no nome das filiais brasileiras. Nesse grupo merece destaque uma empresa do setor eletro-eletrônico, que reúne, a cada três meses, um comitê de patentes onde são selecionados projetos interessantes e que possuem relevância e retorno para o negócio e caso este projeto seja aprovado a patente é registrada em nome da filial brasileira que tem um orçamento específico para investimento independente da aprovação da matriz.

Segundo o gestor de outra empresa que detém uma estrutura de patenteamento interessante e vem obtendo bons resultados, sendo umas das multinacionais com maior número de patentes registradas pela subsidiária brasileira, uma das condições para que uma subsidiária entre no mapa de competências da companhia é gerar um número de patentes considerável. Ele ainda deixa claro que o Brasil já é centro de excelência em algumas áreas que acabam gerando registros de muitas patentes em órgão nacionais e internacionais. De acordo com o entrevistado, somente no EPO, esta empresa conseguiu 10 patentes entre 1996 e 2000 e 24 de 2001 a 2005 que tiveram a participação do Brasil. 
Houve, também, uma empresa do setor farmacêutico que demonstrou bastante interesse por desenvolver pesquisas básicas e aplicadas no Brasil. Segundo a empresa, atualmente não há porque não existir pesquisa de base no Brasil, dado que há uma legislação de direitos de propriedade intelectual no país. O entrevistado ainda marcou de forma enfática que o Brasil apresenta uma situação mais consolidada daquela encontrada na China, país que ainda "caminha" para a construção da legislação de propriedade intelectual.

Seguindo a tendência e buscando melhorar as políticas de patenteamento para o Brasil, pôde-se perceber em entrevista realizada com outra EMN que ela pretende começar a patentear suas inovações em subsidiárias espalhadas pelo mundo. Até 2006 tudo que era criado e merecia ser registrado era feito através da matriz, no entanto, o tratamento dado as patentes foi revisto e a partir de fevereiro de 2007 surgiu a motivação para que a empresa comece a patentear no Brasil, uma vez ampliada suas competências em P\&D locais.

Uma das empresas entrevistadas, apesar de ser vista no mercado mundial como notoriamente inovadora, apresenta uma situação diferente. A empresa se localiza no grupo daquelas que só registram por intermédio do Brasil as patentes menos importantes e que serão desenvolvidas apenas para o mercado local. Descobertas que despertam interesse para mercados de outros lugares são registradas pela matriz da companhia. Alem disso, a empresa deixa muito claro que tem autorização para tentar comprar os direitos sobre as invenções desenvolvidas por outros pesquisadores brasileiros que não são ligados à firma, mesmo relatando que isso é muito complexo e requer muita pesquisa sobre a originalidade da pesquisa em questão.

Apesar de não possuir nenhum diferencial para o Brasil, uma empresa petrolífera presente em praticamente todo o mundo, afirmou que ainda não desenvolveu uma política para patentear o que for desenvolvido aqui. Segundo o gerente entrevistado, a área de P\&D 
no país ainda é rudimentar, mas a medida em que ela for se desenvolvendo, a empresa pretende incentivar pesquisas mais avançadas no Brasil, condição em que já se encontram outros centros da empresa espalhados pelo mundo.

A maior parte das empresas entrevistadas - 34\% do total - apresenta uma condição similar à descrita a seguir: o responsável pela área de $\mathrm{P} \& \mathrm{D}$ da companhia no Brasil respondeu em poucas palavras que a empresa concentra todas as suas patentes em nome da matriz européia e mesmo que haja produtos, processos ou aplicações criados por brasileiros em qualquer subsidiaria ao redor do mundo, as patentes geradas serão anotadas em nome da matriz. 


\section{7- CONSIDERAÇÕES FINAIS}

Terminada a exposição dos resultados obtidos durante essa pesquisa, é hora de discorrer sobre as considerações finais desse pesquisador sobre os temas abordados e a elucidação dos objetivos a que este trabalho se propunha.

O problema de pesquisa que deu origem a todo o trabalho que foi realizado constatou a necessidade de se analisar a representatividade do $\mathrm{P} \& \mathrm{D}$ das subsidiarias das empresas estrangeiras no Brasil comparado-as às subsidiarias das mesmas na Índia e na China em termos de resultados expressos em indicadores de C\&T.

Para tanto, foram coletados e analisados registros de patentes e dados bibliométricos de diversas empresas multinacionais que têm filiais nos três paises alvo desse estudo e foram utilizadas respostas de entrevistas qualitativas realizadas com gestores de P\&D de algumas dessas empresas.

Por fim, este capítulo traz eventuais limitações que persistem neste trabalho e algumas sugestões de trabalhos que podem se basear nessa dissertação para atingirem resultados que não foram foco neste momento. 


\section{$7.1-$ CONCLUSÕES}

A primeira conclusão que pode ser tirada após a leitura dos dados apresentados diz respeito ao real fortalecimento da tendência da internacionalização dos departamentos de Pesquisa e Desenvolvimento das empresas multinacionais para paises periféricos - como visto na literatura sobre o tema. O crescimento do número de patentes registradas em Brasil, Índia e China de um período do estudo para o outro é marcante e reforça o interesse das multinacionais em espalhar seus núcleos de pesquisa pelo mundo e tirar proveito das condições dadas por outros paises e das habilidades dos cientistas locais.

Mesmo com esse grande crescimento visto de um panorama geral, as patentes requeridas por Brasil, Índia e China ainda são pouco significativas dentro de cada empresa, quando confrontadas ao total que cada uma delas patenteia.

Em relação aos setores da economia que têm resultados mais expressivos quando se trata de registrar as patentes de suas descobertas, foi evidente o quanto se sobressaíram as empresas alimentícias, as farmacêuticas, as químicas e as que trabalham com tecnologia da informação. O setor automotivo é pouco representativo, principalmente devido ao fato das grandes companhias do setor estarem presentes nos países estudados apenas com escritórios administrativos, estruturas comerciais, assistência técnica e montadoras dos automóveis desenvolvidos no exterior.

Diante de tudo que foi visto no referencial teórico e no levantado dos dados recolhidos, pode-se concluir que a grande parte das subsidiarias que possuem algum tipo de núcleo de P\&D nos três paises selecionados para este estudo podem ser consideradas como unidades de transferência de tecnologia ou de tecnologia endógena. O foco dessas unidades é solucionar eventuais problemas técnicos de produtos presentes no mercado local ou, 
confirmando o que foi dito por Galina (2001), adaptar as inovações descobertas em outros paises às condições peculiares dos novos consumidores.

Desta forma, seguindo o que é adotado pela literatura, dificilmente uma empresa com sede nos paises desenvolvidos monta uma unidade em Brasil, Índia ou China para ser centro de P\&D global, quando isso acaba acontecendo é por evolução natural de alguma área de pesquisa dessa filial ou graças a aquisição de alguma empresa local que já tenha P\&D estruturado e em condição de competir internacionalmente, o que aconteceu com a Whirpool para o centro de P\&D da Brastemp, por exemplo.

Com intenção de mudar esse fato, os paises em desenvolvimento começaram a desenvolver políticas de atração de investimentos em pesquisas mais avançadas e já conseguiram colher alguns bons resultados. Dentre as medidas que já estão sendo tomadas por Brasil, Índia e China, cada um deles com suas prioridades e em diferentes estágios de evolução, estão investimentos em infra-estrutura, incentivos financeiros e investimentos para formação de profissionais qualificados.

Seguindo essa nova lógica, vem ocorrendo algo similar ao que é defendido por Pearce (1999), o P\&D descentralizado tem passado por uma transformação crucial e deixou de ser apenas ofertante de suporte técnico, passou a ser um diferencial no concorrido mercado contemporâneo.

Hoje, cada um dos três paises já é considerado centro mundial em algumas áreas e empresas interessadas em desenvolver esses temas acabaram instalando unidades que já geraram patentes e artigos acadêmicos por intermédio do Brasil, da Índia e da China. São exemplos clássicos do que foi dito, o desenvolvimento de softwares na Índia que já trouxe 14 patentes para a ST Microelectronics e o setor de higiene pessoal para o Brasil, onde a 
Johnson \& Johnson conseguiu 34 patentes, trabalhando principalmente com sanitary napkins e hygienic napkins.

Em virtude dessa concentração de expertise de cada país em apenas algumas áreas do conhecimento, cada um deles conseguiu consagrar poucas empresas como detentoras de patentes com inventores ou solicitantes locais. Das 112 empresas selecionadas como universo desta pesquisa, apenas cerca de 30 detinham patentes nos paises considerados para esse estudo, esse é mais um ponto que reforça a pouca importância que é dada pelas empresas multinacionais aos centros de pesquisa e desenvolvimento dos paises em desenvolvimento.

Ainda reforçando, grande parte dessas poucas empresas que têm patentes em Brasil, Índia e China, possuem uma ou duas patentes com inventores nativos desses paises, situação que deve ser considerada no caso de um mapeamento de áreas de P\&D estruturados, já que esse casos são, muito provavelmente, isolados e devem ser vistos de separadamente.

O número mais substancioso de artigos indexados ligados às empresas estudadas deve ser observado com cautela, pois muitos deles não refletem avanços tecnológicos das empresas nos locais onde foram realizados. Há artigos que tratam de outros temas e utilizam experiências das empresas para ilustrar o que é dito, isso é muito comum na área da administração com os estudos-de-caso.

Através do estudo da correlação entre as áreas do conhecimento dos artigos publicados e das patentes registradas, chegou-se a conclusão que a situação dos três paises, que vista a partir dos números gerais parece diferente, é muito parecida (principalmente para o segundo período da analise dos dados). Todos tiveram correlações positivas, ou seja, as duas variáveis - classificação de bibliométricos e de artigos - movem-se juntas no 
mesmo sentido. Alem disso, quando se exclui Tata e Whirpool do estudo (pelo fato de terem origem em um dos paises estudados - Índia e Brasil respectivamente) todos os índices encontrados para o segundo período ficam muito próximos de 0,50 e reforçam a similaridade das condições atuais.

Por conseguinte, fica exposto aqui que a principal ferramenta utilizada para comparar o Brasil à Índia e a China no que tange a maturação dos departamentos da P\&D das subsidiarias das empresas translacionais e a continuidade das pesquisas realizadas deixou os três paises em condições muito semelhantes. Condição esta pouco cômoda, mas ao menos pareia à dos principais concorrentes.

Ainda há tempo para o Brasil conquistar o status de país em desenvolvimento mais indicado para a instalação de unidade focadas na criação de produtos ou processo inovativos em escala global. No entanto, o que pôde ser observado durante a busca por elucidar o terceiro objetivo especifico dessa dissertação é que as EMNs ainda não vêem o país desta foram.

Mais da metade dos gerentes de P\&D das empresas entrevistadas sobre suas eventuais políticas para desenvolver patentes no Brasil afirmou que suas companhias não possuem nenhum plano consolidado para incentivar os cientistas a buscarem novidades. Fica evidente, mais uma vez, o papel periférico que o país tem no processo de pesquisa de novas tecnologias e desenvolvimento de novos produtos ou processo para essa empresas que na maior parte das vezes mantêm seus centros de pesquisa diretamente ligados às matrizes. 


\section{2 - LIMITAÇÕES DO ESTUDO E SUGESTÃO DE NOVAS PESQUISAS}

Por se tratar de um trabalho que se propôs a fazer classificações inéditas, durante sua execução surgiram alguns obstáculos que não puderam ser transpostos inteiramente. A principal dessas limitações diz respeito à categorização dos mais de 1.500 artigos em áreas do conhecimento compatíveis às das patentes no EPO, todo esse processo precisou ser feito pelo autor de forma qualitativa e, mesmo procurando-se ser o mais isento possível, a classificação dos textos pode ser sempre questionada.

Justamente durante esta fase de categorização dos artigos acadêmicos, outro ponto delicado dessa dissertação deve ser apontado. Por serem dados provenientes de diferentes bases que enfatizam diferentes quesitos em suas classificações, houve situações em que não era possível determinar a área do conhecimento - de acordo com o EPO - exata para determinados artigos. Buscando minimizar essa limitação, artigos com temas específicos como Ciência da Computação e Física tiveram que ser incluídos na área do conhecimento "Engenharia em Geral", sendo esta, dentre as disponíveis, a que mais se aproxima das áreas de pesquisa dos autores desses papers.

Uma nova proposta para continuar esse estudo e evitar este viés seria o desenvolvimento de um modelo de classificação em áreas do conhecimento que seja inteiramente aplicável a patentes que seguem a classificação internacional de patentes e artigos indexados no SCI.

Por fim, outra sugestão para que seja dada continuidade a essa pesquisa seria fazer uso dos dados quantitativos reunidos para esta dissertação e trabalhar de forma qualitativa com as empresas que tiveram grande destaque em algum dos indicadores coletados. 
Estudos dos casos em profundidade das empresas multinacionais com origem em paises em desenvolvimento: Whirpool no Brasil e da Tata na Índia, por exemplo, poderiam resultar em ótimos trabalhos. Além de estudos daquelas cujas filiais se destacaram neste estudo, caso de Johnson \& Johnson e Bayer no Brasil, Philips e Microsoft na China e General Eletric e Unilever na Índia. 


\section{8- BIBLIOGRÁFIA}

ALABUQUERQUE, E. M. Patentes de empresas transnacionais e fluxos tecnológicos com o Brasil: observações iniciais a partir de estatísticas de patentes depositadas e concedidas pelo INPI. CEDEPLAR/FACE/UFMG, BELO HORIZONTE, 2000.

ARCHIBUGI, D. e IAMMARINO, S. The policy implications of globalisation of innovation. Research Policy. vol. 28, p. 317-336. 1999.

ARCHIBUGI, D.; PIETROBELLI, C. The globalisation of technology and its implications for developing countries. Windows of opportunity or further burden? Technical forecasting \& social change, Portland, v. 70, p. 861-883, 2003.

BARTLETT, C. A.; GHOSHAL, S. Managing Across Borders: the transnational solution. London: Random House Business Books. 1998.

BASU, I. India noses ahead as R\&D center. Asia Times on Line. 2003. Disponível em: $<$ http://www.atimes.com/atimes/South_Asia/EB20Df08.html>.

BEHRMAN, J. N.; FISHER, W.A. Overseas R\&D Activities of Transnational Companies. Cambridge (MA): Oelgeschlager, Gunn \& Hain. 1980.

businessline/2000/08/28/stories/042820ju.htm>.

CHIESA, V; MANZANI, R. Managing knowloge transfer within multinacional firms. Internacional Journal of Technology Management. Vol. 12, n 4, p. 467 - 476, 1996.

CHIZZOTTI, A. Pesquisa em ciências humanas e sociais. $7^{\circ}$ ed. São Paulo: Cortez, 2005.

DALTON, D.; SERAPIO, M. Globalizing Industrial Research and Development. United States: Office of Technology Policy, US Department of Commerce. September 1999. 
DUFFY, M. E. Methodological triangulation: a vehicle for merging quantitative and qualitative research methods. In Journal of Nursing Scholarship, 19 (3), 1987.

DUNNING, J.; NARULA, R. The R\&D activities of foreign firms in the United States. International Studies of Management \& Organization, v. 25, n.1-2, p. 39-73. 1995.

DUYSTERS, G. e HAGEDOORN, J. Internationalization of Corporate Technology Through Strategic Partnering: an empirical investigation. Research policy, vol. 25, 1996.

GALINA, S.V.R. O envolvimento do Brasil no desenvolvimento tecnológico do setor de telecomunicações medido através de indicadores quantitativos - concessão de patentes e dados bibliométricos. $3^{\circ}$ Congresso Brasileiro de Gestão de Desenvolvimento de Produto. Florianópolis, SC. Setembro 2001.

GALINA, S.V.R.; BORTOLOTI, L. Subsidiaries involvement in technological development of telecommunication industry: results from S\&T indicators. REAd. Edição 42, Vol. 10, No. 6, Nov - Dez 2004.

GASSMANN, O.; VON ZEDWITZ, M. Trends and determinants of managing virtual R\&D teams. R\&D Management, Oxford, v. 33, n. 3, p. 243-262, 2003.

GERYBADZE, A.; REGER, G. Globalisation of R\&D: recent changes in the management of innovation in transnational corporations. Research Policy, Amsterdam, v. 28, n. 2/3, pp. 251-274, 1999.

GIL, A. C. Métodos e técnicas de pesquisa social. $5^{\circ}$ ed. São Paulo: Atlas, 1999.

GOMES, R. A Internacionalização das Atividades Tecnológicas pelas Empresas Transnacionais: elementos de organização industrial da economia da inovação. 2003. 190p. Tese (Doutorado). Instituto de Economia da Universidade Estadual de Campinas, UNICAMP, Campinas, 2003. 
GOMES, R. O papel das subsidiárias e a internacionalização das atividades tecnológicas pelas empresas transnacionais (ETNs). Gestão e Produção, Vol. 10, No 3, p. $267-281$, Dez 2003.

GRANSTRAND, O. Internationalization of corporate R\&D: a study of Japanese and Swedish corporations. Research Policy, 28, p. 275-302. 1999.

GREGORY, D; OLIVEIRA, M. F. B. A. O Desenvolvimento de ambiente favorável no Brasil para a atração de investimento estrangeiro direto. 2005

HAKANSON, L.; NOBEL, R. (a) Foreign research and development in Swedish multinationals. Research Policy, vol. 22, p.373-396, 1993.

HAKANSON, L.; NOBEL, R. Determinants of foreign R\&D in Swedish multinationals. Research Policy, v. 22, n. 5-6, p. 397-411, 1993.

HOOD, N.; YOUNG, S. US multinationals R\&D: corporate strategies and policy implications for the UK. Multinational Business, vol. 2, p. 10-23. 1982.

Indicadores de ciência, tecnologia e inovação em São Paulo. Fapesp, 2004.

JICK, T. D., Mixing qualitative and quantitative methods: triangulation in action, In Administrative Science Quarterly, vol. 24, no. 4, December 1979

LACERDA, A C. Globalização e Investimento Estrangeiro no Brasil - Ed. Saraiva, Rio de Janeiro, RJ, 2004.

MAIORES E MELHORES. Revista Exame, São Paulo, v. 28, 2004.

Manual de Oslo - Proposta de diretrizes para coleta e interpretação de dados sobre inovação tecnológica. 2006.

MARTINS, G. de A. Estudo de caso: uma estratégia de pesquisa. São Paulo: Atlas, 2006.

OECD. Internationalisation of Industrial R\&D: patterns and trends. OECD. Paris. 1998. 
Organisation for ecomomic co-operation and development. The measurement of scientific and technological activities using patent data as science ant technology indicators. Patent Manual 1994.

PAPANASTASSIOU, M.; PEARCE, R. The creation and application of technology by MNEs' subsidiaries in Europe, and their role in a global-innovation strategy. Discussion Papers in International Investment and Business Studies, series B, vol VI (1994/95), Department of Economics, University of Reading. maio de 1994a. Draft.

PAVITT, K. Uses and abuses of patents statistics. In: van Raan, A.F.J. Handbook of quantitative studies of science and technology. The Netherlands, 1988.

PEARCE, R. Decentralised R\&D and strategic competitiveness: globalised approaches to generation and use of technology in multinational enterprises (MNEs). Research Policy 28, p.157-78. 1999.

PEARCE, R. The internationalisation of research and development by multinational enterprises. London: MacMillan. 1989

PEREIRA, J. M. Política industrial, propriedade intelectual e desenvolvimento. Revista Espaço Acadêmico, Nº 39, Agosto de 2004.

IBGE, Pesquisa de Inovação Tecnológica - PINTEC

QUEIROZ, S.R.R. Globalização da P\&D: Oportunidades para o Brasil, Parcerias Estratégicas, $n^{\circ}$ 20, $3^{\text {a }}$ Conferência Nacional de C,T\&I, Junho 2005.

REDDY, P. Globalization of Corporate R\&D: Implications for Innovation Systems in Host Countries. Routledge: London, 2000.

RICHARDSON, R. J. Pesquisa social: métodos e técnicas. São Paulo, Editora Atlas, 1985. 
RICYT/CYTED/OEA. Indicadores de C\&T Iberoamericanos/Interamericanos. Argentina, 1999.

RONSTADT, R. International R\&D: the establishment and evolution of research and development abroad by US multinationals. Journal of International Business Studies, $\mathrm{n}$. 9, p. 7-24. 1978.

SACHWALD, F.. In: SACHWAL, F. Les défis de la mondialisation - Innovation Mondialisation et systèmes nationaux et concurrence. Paris: Masson. 1994.

SCHUMPETER, J. A, A Teoria do desenvolvimento econômico, São Paulo: Editora Abril, 1982.

STAL, E. Empresas Transnacionais no Brasil e a Descentralização das Atividades de Pesquisa e desenvolvimento. Anais do XXII Simpósio de Gestão da Inovação Tecnológica, Salvador, Bahia, Universidade de Salvador, Novembro de 2002.

TESTA, J. A base de dados ISI e seu processo de seleção de revistas. Ciência da Informação, Brasília, v.27, n.2, p.233-235, maio/ago. 1998.

THOMSON, R., NELSON, R, The internationalization of technology, 1874-1929: evidence from US, British and German patent experience. New York: Columbia University.

UNCTAD. The impact of FDI on development: globalization of R\&D by Transnational corporations and implications for developing countries. TD/B/COM.2/EM.16/2, October, 2004.

UNCTAD. World Investment Report 2003: FDI Policies for Development: National and International Perspectives. Geneva: United Nations, Unctad (Internet edition). 2003. Disponível em: < http://www.unctad.org/wir>. 
VASCONCELLOS, E \& VASCONCELLOS L. R\&D Decentralization and Global Competitiveness. Workshop MULTICOM-21, Miami, Novembro de 1995.

VENKITARAMANAN, S. India: FDI and technology: learning from the chinese VIOTTI, E.B., MACEDO, M.M. Indicadores de ciência, tecnologia e inovação no Brasil. Editora Unicamp.

YIN, R. Estudos de caso: planejamento e métodos. $3^{\circ}$ ed. Porto Alegre: Bookman, 2005. 
ANEXOS

Tabela 23- Modelo de tabela para formatação dos dados coletados

\begin{tabular}{|c|c|c|c|c|c|c|c|}
\hline Empresa & Período & $\begin{array}{c}\begin{array}{c}\text { Solicitante } \\
\text { China }\end{array} \\
\end{array}$ & \begin{tabular}{|c|}
$\begin{array}{c}\text { Solicitante } \\
\text { Índia }\end{array}$ \\
\end{tabular} & $\begin{array}{c}\text { Solicitante } \\
\text { Brasil }\end{array}$ & \begin{tabular}{|c|} 
Inventor \\
China
\end{tabular} & \begin{tabular}{|c|}
$\begin{array}{c}\text { Inventor } \\
\text { India }\end{array}$ \\
\end{tabular} & \begin{tabular}{|c|}
$\begin{array}{c}\text { Inventor } \\
\text { Brasil }\end{array}$ \\
\end{tabular} \\
\hline$A b b$ & $\begin{array}{l}1 \\
2\end{array}$ & & & & & & \\
\hline $\begin{array}{c}\begin{array}{c}\text { Adobe Systems } \\
\text { Incorporated }\end{array} \\
\end{array}$ & $\begin{array}{l}1 \\
2\end{array}$ & & & & & & \\
\hline Atlas & $\begin{array}{l}1 \\
2\end{array}$ & & & & & & \\
\hline $\begin{array}{l}\text { Air Products } \\
\text { and Chemicals }\end{array}$ & $\begin{array}{l}1 \\
2\end{array}$ & & & & & & \\
\hline Ajinomoto Co. & $\begin{array}{l}1 \\
2 \\
\end{array}$ & & & & & & \\
\hline Astrazeneca & $\begin{array}{l}1 \\
2\end{array}$ & & & & & & \\
\hline $\begin{array}{c}\text { Aracruz } \\
\text { Celulose S.A. }\end{array}$ & $\begin{array}{l}1 \\
2\end{array}$ & & & & & & \\
\hline Avon & $\begin{array}{l}1 \\
2 \\
\end{array}$ & & & & & & \\
\hline Aventis & $\begin{array}{l}1 \\
2 \\
\end{array}$ & & & & & & \\
\hline Bayer & $\begin{array}{l}1 \\
2\end{array}$ & & & & & & \\
\hline Bosch & $\begin{array}{l}1 \\
2\end{array}$ & & & & & & \\
\hline
\end{tabular}


Tabela 24- Empresas escolhidas para análise de patentes e dados bibliométricos

\begin{tabular}{|c|c|}
\hline $3 \mathrm{M}$ & Intel \\
\hline ABB Ltda & International Paper \\
\hline Abbott Laboratories & Interprint \\
\hline Accenture & Izilda de Fátima Victor \\
\hline Accor & Johnson \& Johnson \\
\hline Acesita & KBHC Tabacos \\
\hline Aços Villares & Kenko do Brasil \\
\hline Adobe Systems & Kimberly-Clark \\
\hline Adubos Trevo & Kraft Foods \\
\hline AES & Kvaener Oilfield Products \\
\hline AGCO 2 & Lafarge \\
\hline Agfa Gevaert & LG de São Paulo \\
\hline Air Products Brasil Ltda & Light \\
\hline Ajinomoto & Lojas Renner \\
\hline Alcan & Lojas Yamada \\
\hline Alcatel & L'Oreal \\
\hline Alcoa & Lucent Technologies \\
\hline Alfa Laval & Mabe \\
\hline Alunorte & Mabe SA \\
\hline Amanco 2 & Mahle Metal Leve \\
\hline American Banknote & Makro \\
\hline Americanas.com & Marconi \\
\hline Amsted Maxion & Matsushita Electric \\
\hline Anglo American & McDonald\&apos;s \\
\hline Aracruz Celulose & Medidata \\
\hline Arno & Merck \\
\hline Atlas Schindler & Merck Sharp \& Dohme \\
\hline Autometal & Meridional de Tabacos \\
\hline Avon 2 & Metso \\
\hline B. Braun & Michelin \\
\hline Bahia Pulp & Microsoft Brasil \\
\hline Bandeirante Energia & Millenium Pharmaceuticals \\
\hline Barry Callebaut & Mitsubishi Motors \\
\hline Basf & Monroe \\
\hline Batávia & Monsanto \\
\hline Bayer & Moore \\
\hline Behr Brasil & Motorola \\
\hline Belgo Siderurgia S/A & Multibrás \\
\hline Bic Amazônia & NEC \\
\hline Black \& Decker & Nestlé \\
\hline Blue Tree Hotels & Nexans Brasil S.A. \\
\hline Boehringer Ingelheim & Nibrasco \\
\hline Borealis & Nokia \\
\hline Bosch & Norsa \\
\hline Brasfumo & Norske Pisa \\
\hline
\end{tabular}




\begin{tabular}{|c|c|}
\hline Brasil Telecom & Nortel Networks \\
\hline Brasmetal Waelzholz & Novadutra \\
\hline Bridgestone-Firestone & Novartis Biociências \\
\hline Bristol Meyer & Novo Nordisk \\
\hline Bunge Alimentos & Nutron Alimentos \\
\hline Cachoeira Dourada & Oracle do Brasil 2 \\
\hline Café Iguaçu & Otis \\
\hline Camil & Owens Illinois Brasil \\
\hline Canon do Brasil & Parmalat \\
\hline Carbocloro & Petróleo Sabbá \\
\hline Cargill & Peugeot-Citroën \\
\hline Carrefour 2 & Pfizer \\
\hline Caterpillar & Philips \\
\hline CBB-AmBev & Pilkington \\
\hline CBCC & Pirelli Pneus \\
\hline CBMM & Placas do Paraná \\
\hline Celpe & Polyenka \\
\hline Cenibra & Prada \\
\hline Cerj & Prensas Schuller \\
\hline CHS do Brasil & Procter \& Gamble \\
\hline Ciba Specialty Chemicals & Prosegur \\
\hline Cimentos do Brasil & Prysmian \\
\hline Cinemark Brasil & Qualix \\
\hline Cisco Systems & Reckitt Benckiser \\
\hline Clariant & Reckitt Benckiser \\
\hline Claro-Americel & Renault \\
\hline Claro-Telet & Repsol YPF Brasil \\
\hline $\mathrm{CNH}$ & Rexam \\
\hline Coelce & Rhodia \\
\hline Cofap & Rhodia Poliamida \\
\hline Cognis & Rigesa \\
\hline Coinbra & Rio Paracatu Mineração \\
\hline Colgate-Palmolive & Roche \\
\hline Comau do Brasil & Saint-Gobain Canalização \\
\hline Comgás & Saint-Gobain Vidros \\
\hline Computer Associates & Samarco \\
\hline Confab Industrial & Samsung \\
\hline Consist & Sandvik do Brasil \\
\hline Cooper Cameron do Brasil & Sanofi Aventis \\
\hline Copebrás & Sanyo Electric \\
\hline Cosern & SAP \\
\hline CPM & Schenectady Crios \\
\hline $\begin{array}{l}\text { Crosshueller Indústria de Máquinas } \\
\text { Ltda. }\end{array}$ & Schering \\
\hline Crown & Seara \\
\hline DaimlerChrysler 2 & Shell \\
\hline Dana Albarus & Showa \\
\hline Danone & Siemens \\
\hline Datamec & Sipcam \\
\hline
\end{tabular}




\begin{tabular}{|c|c|}
\hline Degussa & Smart Modular Technologies \\
\hline Dell & Solvay \\
\hline Delphi & Solvay \\
\hline Deten & Sonae \\
\hline Diageo & Sony \\
\hline Diebold Procomp & Souza Cruz \\
\hline Dixie Toga & Spal Coca Cola \\
\hline Dow Brasil SA & Springer Carrier \\
\hline Du Pont & ST Microletronics \\
\hline Dufer & Submarino \\
\hline Duke Energy & Supergasbrás \\
\hline Dynea Brasil & Suzano Petroquímica \\
\hline Eastman Kodak & Syngenta \\
\hline Eaton & Tafisa Brasil \\
\hline Ecovias & Tangará \\
\hline EDN Poliestireno & Tata Consulting Service \\
\hline Electrolux & Techint \\
\hline Elektro & Teksid \\
\hline Eli Lilly & Telefônica \\
\hline Elma Chips/Quaker (pepsico) & Telefônica São Paulo \\
\hline Embraco & Tenaris Confab \\
\hline Embratel & Terra \\
\hline Endesa Fortaleza & Texaco \\
\hline Energias do Brasil & $\begin{array}{c}\text { Texas Instruments Semicondutores } \\
\text { e Tecnologias Ltda. }\end{array}$ \\
\hline Epcos 1 & Textron \\
\hline Ericsson & ThyssenKrupp \\
\hline ESAB & Ticket \\
\hline Escelsa & TIM Celular \\
\hline Esso & Tintas Coral \\
\hline Faber Castell S.A. & TNT Logistics \\
\hline Fertilizantes Mitsui & Toshiba \\
\hline Fiat Automóveis & Tower Automotive do Brasil \\
\hline Ficap & Toyota \\
\hline FL Brasil & Tractebel Energia \\
\hline FMC & TRW Automotive \\
\hline Ford & TSN \\
\hline Furukawa & Ucar \\
\hline GDC & Unilever Brasil \\
\hline General Eletric & Universal Leaf \\
\hline General Motors & V \& M Tubes \\
\hline Gevisa & Valesul \\
\hline GKN do Brasil & Vega Engenharia \\
\hline GlaxoSmithKline & Viaoeste \\
\hline Glencore & Villares Metals \\
\hline Gonvarri Brasil & Visteon \\
\hline Goodyear & Vivo \\
\hline Grob & Voith Paper \\
\hline Gtech & Voith Siemens \\
\hline
\end{tabular}




\begin{tabular}{|c|c|}
\hline Guarani 1 3 & Volvo \\
\hline HCl Brasil & Wal-Mart \\
\hline Henkel & Wheaton \\
\hline Hispanobrás & Xerox \\
\hline Holcim & Yakult S.A. Indústria e Comércio \\
\hline Honda & Yamaha Motor \\
\hline HP Brasil & YKK \\
\hline IBM & ZF Sachs Brasil \\
\hline
\end{tabular}


Tabela 25- Empresas pré-selecionadas para estudos de caso

\begin{tabular}{|c|c|c|c|}
\hline $3 \mathrm{M}$ & Delphi & Merck & $\begin{array}{c}\text { Tower Automotive } \\
\text { do Brasil }\end{array}$ \\
\hline ABB Ltda & Dow Brasil SA & Motorola & Toyota \\
\hline Aços Villares & Eaton & Multibrás & Tractebel Energia \\
\hline Adobe Systems & Electrolux & Nestlé & TRW Automotive \\
\hline AES & Eli Lilly & $\begin{array}{c}\text { Nexans Brasil } \\
\text { S.A. }\end{array}$ & Unilever Brasil \\
\hline $\begin{array}{c}\text { Air Products Brasil } \\
\text { Ltda }\end{array}$ & Embraco & Nortel Networks & V\&M do Brasil \\
\hline Ajinomoto & Energias do Brasil & Novartis & Villares Metals \\
\hline Alunorte & Ericsson & $\begin{array}{c}\text { Owens Illinois } \\
\text { Brasil }\end{array}$ & Visteon \\
\hline AMD & ESAB & Pfizer & Voith Paper \\
\hline $\begin{array}{l}\text { American } \\
\text { Banknote }\end{array}$ & Faber Castell S.A. & Philips & Voith Siemens \\
\hline Aracruz Celulose & Fiat Automóveis & Pirelli Pneus & Whirpool \\
\hline Astrazenenca & Ford & Prensas Schuler & Yakult S.A. \\
\hline Atlas Schindler & Freescale & Procter \& Gamble & Yamaha \\
\hline Avon 2 & Furukawa & Renault & ZF Sachs Brasil \\
\hline B. Braun & General Motors & Repsol YPF Brasil & \\
\hline Bahia Pulp & GlaxoSmithKline & Rhodia & \\
\hline Bayer & Gonvarri & Robert Bosch & \\
\hline $\begin{array}{c}\text { Belgo Siderurgia } \\
\text { S/A }\end{array}$ & Holcim & Roche & \\
\hline $\begin{array}{l}\text { Boehringer } \\
\text { Ingelheim }\end{array}$ & HP Brasil & Saint-Gobain & \\
\hline Borealis & IBM & Sanofi Aventis & \\
\hline Bristol Meyer & $\begin{array}{c}\text { International } \\
\text { Paper }\end{array}$ & Shell & \\
\hline Carbocloro & Interprint & Siemens & \\
\hline Clariant & $\begin{array}{c}\text { Johnson \& } \\
\text { Johnson }\end{array}$ & Souza Cruz & \\
\hline Coelce & Kraft Foods & $\begin{array}{c}\text { ST } \\
\text { Microelectronics }\end{array}$ & \\
\hline Colgate-Palmolive & LG & Submarino & \\
\hline Comgás & Lojas Renner & Syngenta & \\
\hline Corn Products & $\begin{array}{c}\text { Lucent } \\
\text { Technologies }\end{array}$ & Tata & \\
\hline CPM & Mabe & Tenaris Confab & \\
\hline Dana Albarus & Mahle Metal Leve & $\begin{array}{l}\text { Texas Instruments } \\
\text { Semicondutores e } \\
\text { Tecnologias Ltda. }\end{array}$ & \\
\hline Dell & McDonald's & $\begin{array}{c}\text { Thyssen Krupp } \\
\text { Elevadores }\end{array}$ & \\
\hline
\end{tabular}

